\title{
Electrochemical Carbon Dioxide Reduction on Rough Copper Surfaces
}




\section{ELECTROCHEMICAL CARBON DIOXIDE REDUCTION ON ROUGH COPPER SURFACES}




\section{PROMOTIECOMMISSIE}

\section{Voorzitter}

Prof. dr. ir. J.W.M. Hilgenkamp

Universiteit Twente, TNW

\section{Promotor}

prof. dr. G. Mul

Universiteit Twente

\section{Leden}

prof. dr. P.J. A. Kenis

University of Illinois at Urbana Champaign

em. prof dr. J. A. R. Van Veen

Technische Universiteit Eindhoven

prof. dr. M.T.M. Koper

Universiteit Leiden

prof. dr. N.E. Benes

Universiteit Twente

prof. dr. H.J.M. Bouwmeester

Universiteit Twente

The research described in this thesis was carried out in the Photocatalytic Synthesis group within the faculty of science and technology, and the MESA+ institute for Nanotechnology at the University of Twente. Part of the experiments were performed in collaboration with the Catalysis and Surface Chemistry group of the Leiden University, and the Inorganic Membranes group of the University of Twente. This work was financially supported by NanoNextnNL a micro and nanotechnology consortium of the Government of the Netherlands and 130 partners.

Cover Page: Source images courtesy NASA/JPL-Caltech.

Electrochemical Carbon Dioxide Reduction on Rough Copper Surfaces

Ph.D. Thesis, University of Twente, Enschede, the Netherlands

Printed by: Gildeprint drukkerijen, Enschede, the Netherlands

Copyright (C) 2015, Recep Kaş

DOI: $10.3990 / 1.9789036540469$

ISBN: 978-90-365-4046-9 


\title{
ELECTROCHEMICAL CARBON DIOXIDE REDUCTION ON ROUGH COPPER SURFACES
}

\author{
PROEFSCHRIFT \\ ter verkrijging van \\ de graad van doctor aan de Universiteit Twente, \\ op gezag van de rector magnificus, \\ prof. dr. H. Brinksma, \\ volgens besluit van het College voor Promoties \\ in het openbaar te verdedigen \\ op vrijdag 29 januari 2016 om 16.45 uur
}

door

Recep Kaş

geboren op 29 maart 1986

te Bursa, Turkije 
Dit proefschrift is goedgekeurd door de promotor:

prof. dr. G. Mul 
We are going to die, and that makes us the lucky ones. Most people are never going to die because they are never going to be born. The potential people who could have been here in my place but who will in fact never see the light of day outnumber the sand grains of the Sahara. Certainly those unborn ghosts include greater poets than Keats, scientists greater than Newton. We know this because the set of possible people allowed by our DNA so massively outnumbers the set of actual people. In the teeth of these stupefying odds it is you and I, in our ordinariness, that are here. 



\section{Contents}

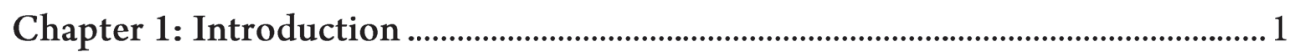

1.1. Global Energy: Supply, Demand and Consequences ...................................... 2

1.2. Opportunities..............................................................................................

1.3. Electrochemical $\mathrm{CO}_{2}$ reduction...............................................................11

1.4. Thesis Outline................................................................................................. 13

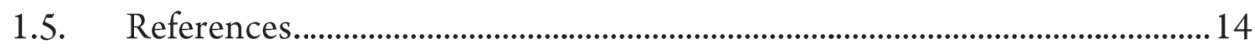

Chapter 2:Experimental Setup and Procedures.............................................................19

$2.1 \quad$ Electrodeposition of $\mathrm{Cu}_{2} \mathrm{O}$ films..................................................................20

2.2. Electrochemical $\mathrm{CO}_{2}$ reduction experiments at ambient pressure...............21

2.3. Electrochemical $\mathrm{CO}_{2}$ reduction experiments at high pressures...................22

2.4. Online electrochemical mass spectroscopy measurements ............................23

2.5. Preparation of $\mathrm{Cu}$ hollow fibers .......................................................................24

2.6. Electrochemical $\mathrm{CO}_{2}$ reduction setup for $\mathrm{Cu}$ hollow fibers...........................25 
2.7. Faradaic efficiency calculation...................................................................26

2.8. Electrochemical surface area measurements ..................................................26

1.9. Calculations for the concentration of species near the electrode surface...27

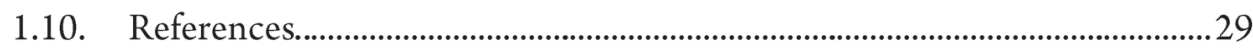

Chapter 3: Controlling the catalytic selectivity of copper nanoparticles during carbon dioxide electroreduction ..........................................................................................31

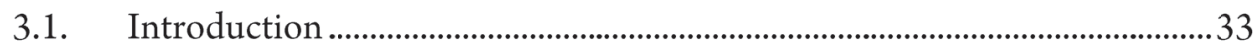

3.2. Results and Discussion .................................................................................

3.2.1. Electrodeposition of $\mathrm{Cu}_{2} \mathrm{O}$ Films.............................................................34

3.2.2. Electrochemical $\mathrm{CO}_{2}$ reduction on different facets of $\mathrm{Cu}_{2} \mathrm{O}$ films.....35

3.2.3. Electrochemical $\mathrm{CO}_{2}$ reduction on (110) $\mathrm{Cu}_{2} \mathrm{O}$ films of increasing

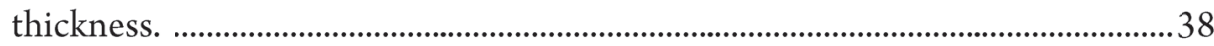

Chapter 4: How ethylene is formed preferentially over methane on copper nanoparticles in carbon dioxide electroreduction .........................................................49

4.1. Introduction ..........................................................................................

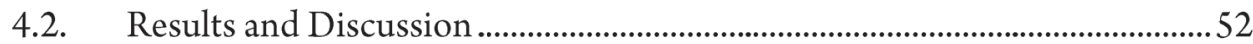

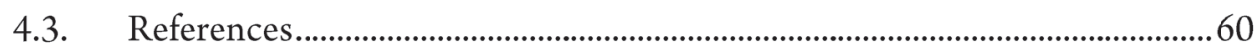

Chapter 5: On the formation of ethane over rough copper electrodes..................65

5.1. Introduction ....................................................................................................67

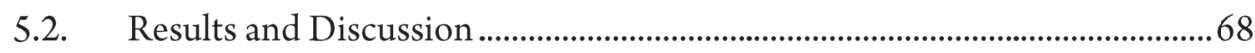

5.2.1. Electrochemical Reduction of Ethylene to Ethane .........................................68

5.2.2. Electrochemical $\mathrm{CO}_{2}$ reduction to Ethane.....................................................72

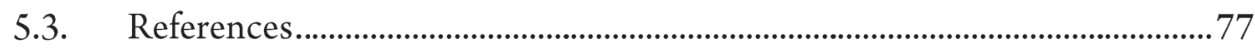


Chapter 6: 3-D porous hollow fiber electrodes for efficient and high-rate electrochemical carbon dioxide reduction ................................................................. 81

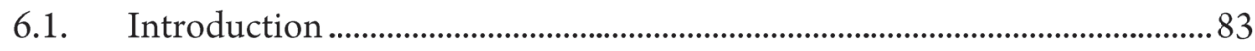

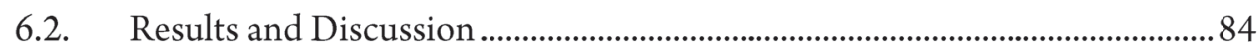

6.3. References...................................................................................................92

Chapter 7: Summary and Outlook.................................................................................97

7.1. Summary ..................................................................................................................

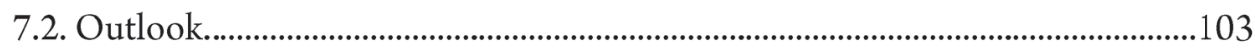

Samenvatting ...................................................................................................................107

Acknowledgement ..........................................................................................................

Publications in Twente .............................................................................................117

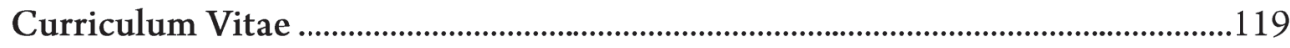





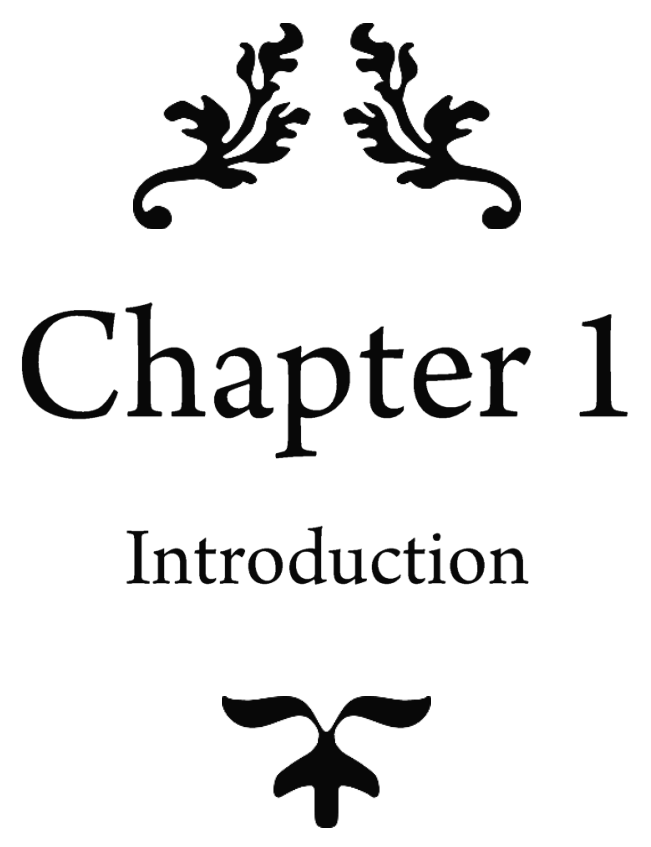




\subsection{Global Energy: Supply, Demand and Consequences}

200.000 years ago, the first Homines sapientes in Africa were hunting, cooking and reproducing, and relied mostly on muscular power. Struggling many years in nature, humans have learned how to make use of different types of energy to increase their quality of life. Now, an average income person in the United States and Europe has a nice warm house, a car, and industrial and technological products, many running on electricity. Such a lifestyle along with the growing population and longer life expectancy give rise to an increasing global energy demand.[1] Coal and wood were the primary source of energy at the beginning of the industrial era. Even though coal still plays an important role in annual energy production, in the $20^{\text {th }}$ century it was substantially replaced by liquid and gaseous hydrocarbons when normalized to the overall energy demand.[2] Today, nearly $80 \%$ percent of the energy ,mainly for residential, industrial and transportation purposes, is supplied by fossil fuels which releases tremendous amounts of carbon dioxide $\left(\mathrm{CO}_{2}\right)$ into the atmosphere.[3] A simple schematic view of the anthropogenic carbon cycle (or flow) to the atmosphere is given in Figure 1.[4] Fossil fuels such as coal, petroleum and natural gas have been formed very slowly over millions of years via different natural processes. Now we are burning these fossil fuels at an incredible rate and the products are almost completely emitted in the form of $\mathrm{CO}_{2}$ to the atmosphere. Nature can recycle part of this emitted 


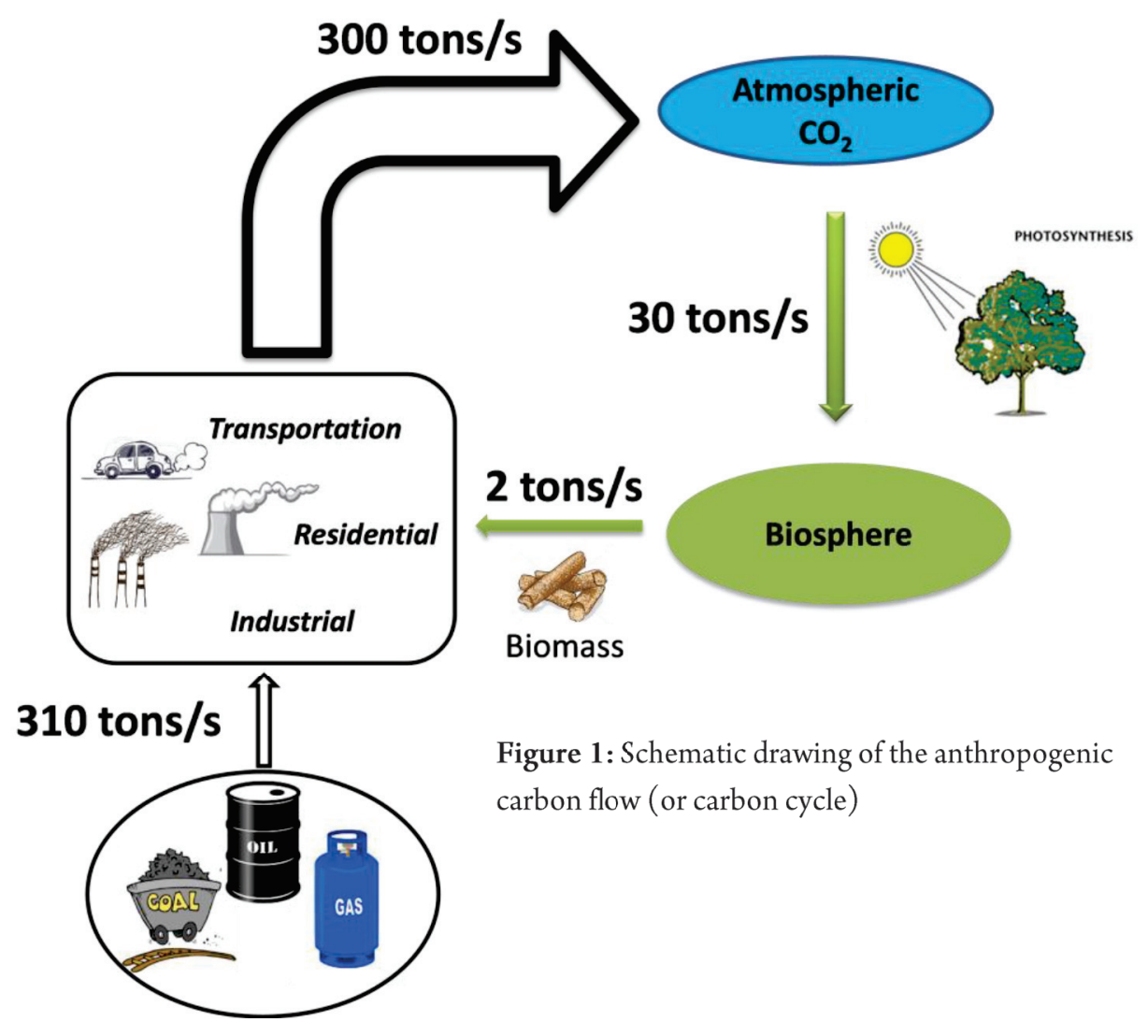

$\mathrm{CO}_{2}(\approx 10 \%)$ by using sunlight via photosynthesis where a small percent of it is used as primary source of energy i.e. in the form of biomass. The rest of the released $\mathrm{CO}_{2}$ accumulates in the atmosphere or is taken up by the ocean when the daily and seasonally fluctuations are discarded. [5]

Geological scientists revealed the global $\mathrm{CO}_{2}$ concentration history, by drilling and analyzing the ice cores that have been formed in East Antarctica over half a million years. [6] The ice cores are up to $3 \mathrm{~km}$ long and contain layers of ice crystals, analogous to tree rings, which belong to the summer and winter cycles of each year. Scientists studied the layers one by one by carefully melting them in a vacuum chamber and traced the $\mathrm{CO}_{2}$ levels back in history. Atmospheric $\mathrm{CO}_{2}$ concentrations oscillated between 200 and 280 part per million (ppm) over the past 420.000 years before the industrial era. The concentration of $\mathrm{CO}_{2}$ has been increasing dramatically over the last century and setting a new record each year, which is explicitly correlated to human 
activity. [7] The concentration of $\mathrm{CO}_{2}$ in the atmosphere is now $401.3 \mathrm{ppm}$ as I write this thesis.[8] Not only has the concentration itself increased but also the rate of increase. The rate of increase has accelerated from about $0.7 \mathrm{ppm}$ per year to $2.1 \mathrm{ppm}$ per year over the last 50 years.[9] The $\mathrm{CO}_{2}$ levels never rose this much in history or at least during the periods that scientists can trace back. Therefore, we have to predict what will be the possible consequences of the $\mathrm{CO}_{2}$ accumulation in the atmosphere.

$\mathrm{CO}_{2}$ played an important role in the past, allowing planet earth to become a host to living organisms. The major gases in the air; $\mathrm{N}_{2}, \mathrm{O}_{2}, \mathrm{CO}_{2}$, and $\mathrm{H}_{2} \mathrm{O}$ allow most of the short wavelength sun radiation to pass through. Nearly half of the solar radiation is absorbed by the surface of the earth and emitted back in longer wavelengths as heat. In Figure 2, absorption spectra of $\mathrm{O}_{3}, \mathrm{CO}_{2}$ and $\mathrm{H}_{2} \mathrm{O}$ are given along with the spectrum

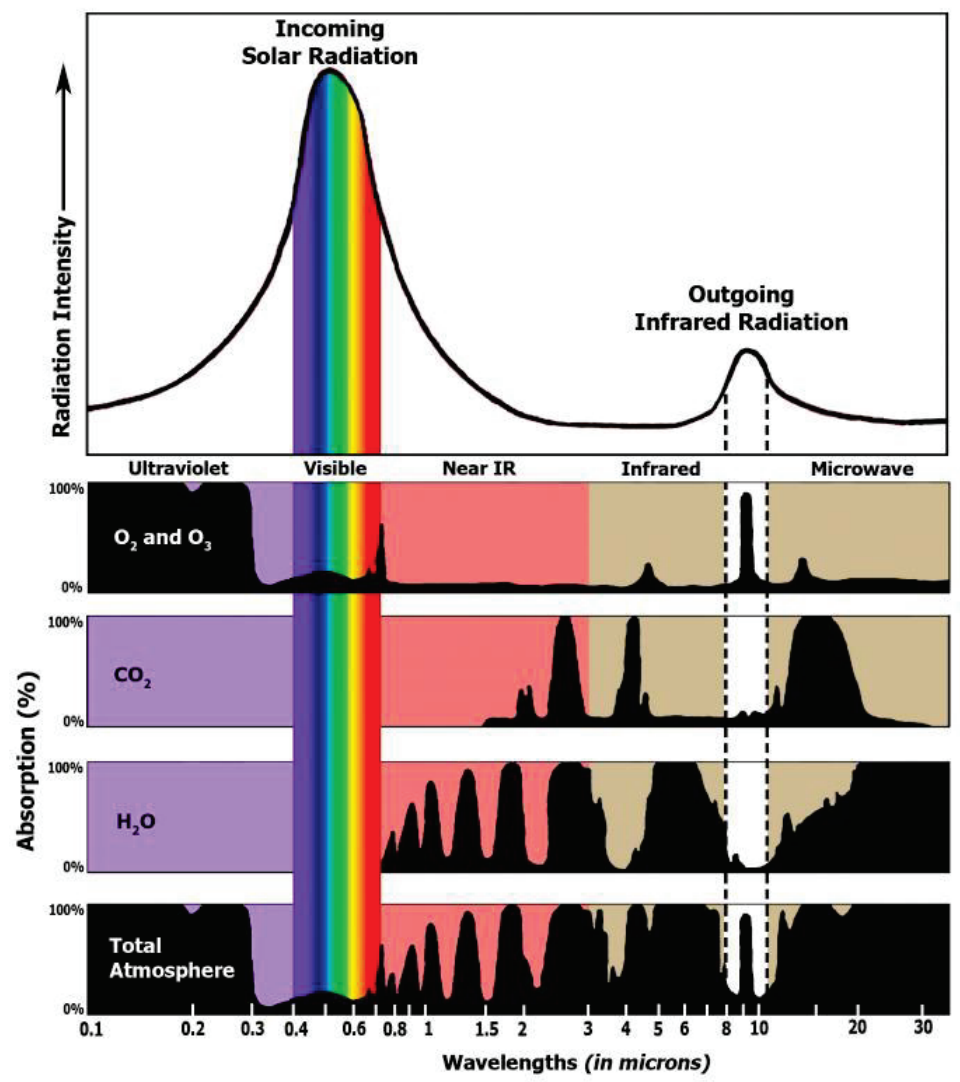

Figure 2: Top panel shows intensity of incoming solar radiation and emitted infrared radiation from the surface of the earth. Bottom panels show the absorption spectrum of some major greenhouse gases. ${ }^{10}$ 
of the light emitted from the surface of the earth.[10] The outgoing infrared radiation is absorbed mainly by water and $\mathrm{CO}_{2}$ and radiated in all directions as heat. This creates an extra source of energy to heat the surface of the earth. Although $\mathrm{O}_{3}$ and $\mathrm{CH}_{4}$ are also good infrared absorbers, they have relatively small concentrations in the atmosphere. If greenhouse gases were not present in the atmosphere, the temperature on earth might be too low to allow evolution of any living organism. What once was a solution, now becomes a problem. Supporting the life on planet earth, the greenhouse gases might lead to extinction of the most evolved animal, the homo sapiens, on earth.

In the $17^{\text {th }}$ century, there were three known types of "air". There was the "common air" that we breathe, "inflammable air" which we call hydrogen and "fixed air" which we call carbon dioxide today. In 1772, Joseph Priestley, an English theologian, mixed water with "fixed air" and invented the first fizzy soft drink in history.[11] Now multi-billion dollar industrial companies are present and millions of people enjoy $\mathrm{CO}_{2}$ saturated soft drinks every day. In 1896, Svante Arrhenius was the first scientist proposing that an increased amount of $\mathrm{CO}_{2}$ might lead to global warming.[12] He calculated that the average temperature of the earth surface is $15^{\circ} \mathrm{C}$ because of the infrared absorption capacity of water and $\mathrm{CO}_{2}$. He suggested doubling the amount of $\mathrm{CO}_{2}$ might cause a rise of $5{ }^{\circ} \mathrm{C}$ in global temperature. At that time scientists found the idea interesting but many of them assumed that natural cycles would balance and regulate the atmosphere. In the 1940s, with the measurements of the absorption spectrum and concentration of $\mathrm{CO}_{2}$ in the atmosphere, the concerns again began to rise. There were many hypotheses whether the earth would cool down due to aerosols, or heat up due to an increase in $\mathrm{CO}_{2}$ levels, until the1980s. [13] The surface temperature of the earth began to rise steadily starting from the $1980 \mathrm{~s}$ which pretty much settled the debate between global warming alarmist, and global cooling advocates. In 1997, there was more than enough evidence to take concerted actions. The Kyoto protocol was negotiated in 1998 which calls for participating countries to regulate the emission of greenhouse gases. Recent reports on the solar activity and temperature increase even convinced many of the most skeptical scientists.[14] The global temperature increased $0.8^{\circ} \mathrm{C}$ over the last century as the solar activity remained relatively constant, and the temperature still continues to rise with a rate of $0.15-0.20$ ${ }^{\circ} \mathrm{C}$ per decade.

The next important question is what will be the consequences of global warming? In our lifetimes, we can say that neither will the oceans boil, nor will we drown in water. For very long term predictions however, we don't exclude that probability. For instance, our nearest neighbor planet Venus has a surface temperature 
around $500{ }^{\circ} \mathrm{C}$ and its atmosphere contains $95 \% \mathrm{CO}_{2} \cdot[15]$ Geological scientists predicted that Venus might have had an earth like atmosphere once.[16] When we look at the consequences that will affect us or our children, the first and most important one is polar ice melting and subsequent sea level rise. Even though evaporation of more water due to global warming leads to more snow, different groups of scientists explicitly showed that the overall effect was loss of ice mass. [17-19] For the end of this century, the predictions for the sea level rise lie between $0.8-2 \mathrm{~m}$ on the basis of ice melting projections and thermal expansion.[20,21] This is enough to submerge big coastal cities including Miami, New York, Amsterdam, Rotterdam, Kolkata, and Guangzhou.[22] Rise in average temperatures will also increase vapor pressure of water, e.g. $1{ }^{\circ} \mathrm{C}$ change will lead to $7.5 \%$ more capacity of holding water vapor. This would eventually increase the rainfalls but only for some regions. Detailed studies show that dry regions will get drier and wet regions will get wetter.[23] Even though the increased $\mathrm{CO}_{2}$ levels will lead to a much faster growth rate of plants and higher yield of farm crops, crop losses due to water shortages, flooding and heat stress is predicted to be more than this gain. Another important effect is the increase in the acidity of the oceans due to more $\mathrm{CO}_{2}$ intake. Studies have shown ocean acidification will have a corrosive effect on shelled organisms such as corals and planktons which eventually might influence the whole food chain. $[24,25]$ Not only marine life but also terrestrial life will struggle with extinction of species and reduced diversity.[26, 27]

More importantly, there might be irreversible effects due to chain of events triggered by global warming. As the average temperature goes up, there will be more dark water to absorb sun light, rather than a reflective ice surface. Similarly, emissions of methane gas were reported in Siberia from the melting ice, which has a much stronger infrared absorption than $\mathrm{CO}_{2} \cdot[28]$ Furthermore, increase of the average global temperature will cause more water to evaporate which was predicted by NASA to double the warming triggered by human $\mathrm{CO}_{2}$ emissions.[29] Global warming will have impacts on all organisms to varying degrees. Any precaution taken to stabilize the greenhouse gas emissions will not be effective in the short term. Rather, it will take centuries to stabilize the $\mathrm{CO}_{2}$ concentrations in the atmosphere [30] All we need to do is accept the problem and take concerted actions. The countries that recognized the problem decades ago already started to produce alternative clean and renewable energy sources. For the short term, the renewable energy sources will not replace fossil fuels completely since the energy demand is simply too large. For example, to supply the whole energy of the world by solar panels(10\% efficient), we need to produce panels with a rate of $650 \mathrm{~m}^{2} \mathrm{~s}^{-1}, 7 / 24$ for the next 40 years.[31] Nevertheless, renewable energy will provide the evolution of energy sources for a greener future, while helping us to 
reduce $\mathrm{CO}_{2}$ emissions and giving opportunities to convert $\mathrm{CO}_{2}$ to useful products and fuels.

\subsection{Opportunities}

Calculations based on the Hubbert theory predict that oil production will peak within 10 years although there are different reports and scenarios.[32, 33] Oil reserves have always been projected to deplete or substantially diminish over the past 50 years. This is most likely related to resources in the Middle East which are poorly known or unreliably reported, while technologies developed to find or extract new sources are limited.[32] The increasing energy demand of large developing countries, namely China and India, also creates a lot of question marks regarding the future energy needs and $\mathrm{CO}_{2}$ emissions. Certainly, under such uncertain and variable conditions and scenarios, immediate measures have to be taken before we face the irreversible effects of global warming.[30]

There are already commercially produced chemicals such as urea, polycarbonates, and salicylic acid using $\mathrm{CO}_{2}$ as precursor. However, demand for these chemicals is small when compared to the overall $\mathrm{CO}_{2}$ emissions. [34] In fact, if all the chemicals, excluding fuels, were produced from $\mathrm{CO}_{2}$, only $10 \%$ of the emissions would be recycled to achieve a carbon neutral chemical industry.[30] Therefore, the conversion to energy dense fuel type molecules or fuel precursors is necessary to cope with the current and projected emissions. Furthermore, the required energy for the conversion has to be supplied from carbon-neutral sources or the net result will be more $\mathrm{CO}_{2}$ emissions. There is no universally applicable method for conversion of $\mathrm{CO}_{2}$ to useful chemicals. By considering the industry, location and other constraints one of the technologies might be more useful than others. Mimicking nature via artificial photosynthesis is the panache, yet the solar radiation is very diffuse and photosynthetic efficiencies and rates are rather low.[35] Electricity from renewables as energy source is a promising technology, including energy sources such as wind, geothermal, hydroelectric, and nuclear. Electrochemical processes directly utilize electricity, therefore they are considered as one of the most suitable technologies for renewable energy storage.[36] Conversion of renewable energy to chemicals would slowly integrate renewable electricity in the chemical industry, and could also supply renewable fuels to the transportation sector, which currently almost completely relies on petroleum-derived liquid fuels.[37] 


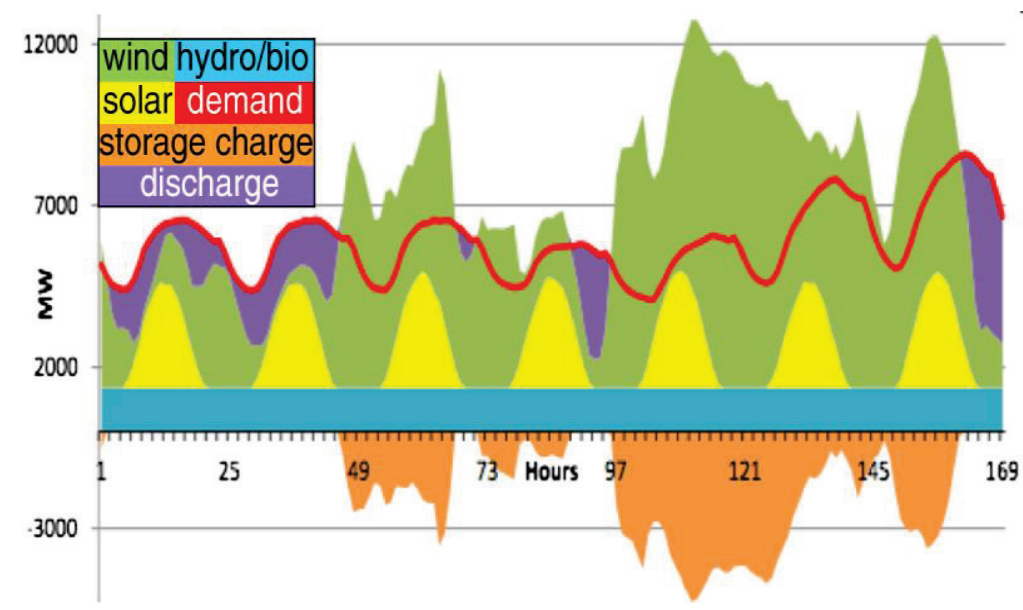

Figure 3: Hourly supply and demand of electricity in July for Minnesota. ${ }^{40}$

Wind and solar energy are quite popular and growing technologies but they are intermittent and not perfectly predictable.[38, 39] In Figure 3, the weekly demand of electricity is given along with supply from different renewable energy sources. [40] Due to the fluctuating and usually unpredictable nature of renewables, the excess electricity produced can be stored in chemical bonds. By the end of the 2014, 1\% and $4 \%$ of the world electricity was supplied by photovoltaics and wind turbines respectively. [41, 42] The future projections of solar and wind energy are usually very difficult and complicated however both sectors are growing with the fastest rate among the renewable energy sources.[43] The upper limit for the intermittent energy sources are projected to be around 15-20\% unless large scale electricity storage is utilized.[44] Therefore, as the energy sources evolve to solar and wind energy, the storage of electricity will become a more important issue. There are many scenarios to store the electricity such as batteries, artificial photosynthesis etc. which is not possible to cover and evaluate in detail in this thesis. Therefore we will discuss mainly how we can integrate renewable electricity to the chemical industry via electrochemical processes.

In Figure 4, some of the different possible routes to incorporate renewable electricity to the chain of the chemical industry are given. Power plants produce a relatively concentrated source of $\mathrm{CO}_{2}$ (3\%-15\%) which might give opportunities for direct utilization without further purification. Recently, studies have shown that it is also possible to reduce $\mathrm{CO}_{2}$ to $\mathrm{CO}$ with high rates in dilute form by using gas diffusion electrodes. [45] Nevertheless, $\mathrm{CO}_{2}$ capture directly from air is a well-established technology which has been used in submarines for decades and intense research has been conducted recently to improve this technology to make it feasible in large scale. $[46-48]$ 


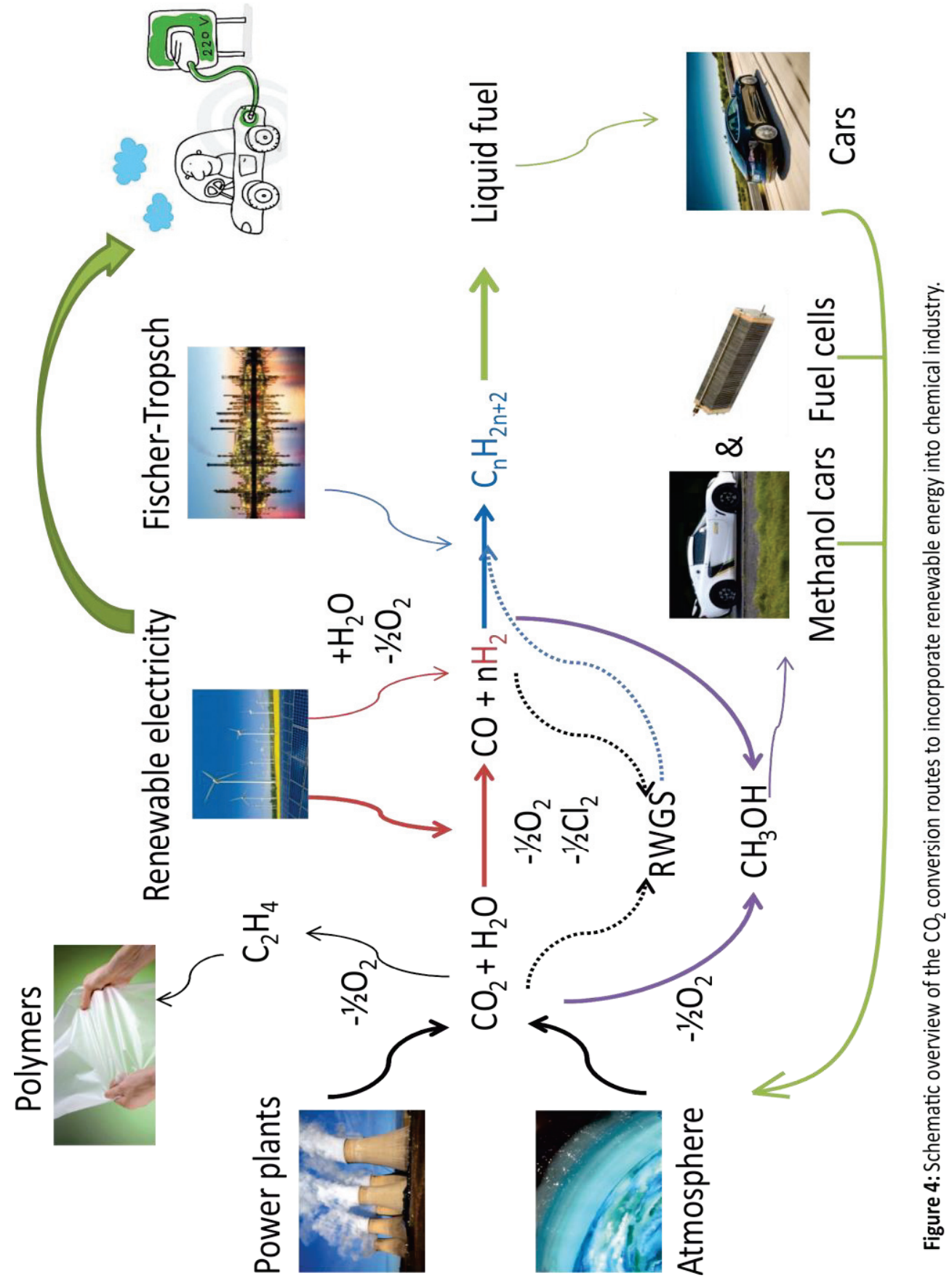


One of the most mature technologies given in Figure 4 is hydrogen production by electrolysis. Norsk Hydro, a Norwegian Company, has produced hydrogen for ammonia synthesis by using water electrolysis for more than 50 years. Currently Alkaline or Polymer electrolyte membrane (PEM) electrolyzers can reach up to $80 \%$ efficiency.[37] Additionally $5 \%$ of the hydrogen is produced annually via electrochemical process during the chlor-alkali process. By combining the captured $\mathrm{CO}_{2}$ with hydrogen produced by renewable electricity, one can produce syngas via the reverse water gas shift (RWGS) reaction. Even though there is no large scale RWGS reactor currently, there could be one available in the near future.[49] However, this kind of industrial process demands continuous supply of power which does not fit well to intermittent renewable sources. On the other hand, PEM electrolyzers have quick startup times and function very well when the amount of electricity varies significantly.[50] Electrochemical $\mathrm{CO}_{2}$ reduction can be an excellent candidate to store excess renewable electricity while recycling the $\mathrm{CO}_{2}$.

In Figure 4, there are three routes given for electrochemical $\mathrm{CO}_{2}$ reduction while certainly more opportunities exist.[51] Ethylene is a very important precursor for important polymers and chemicals such as polyethylene, ethylene oxide, ethylbenzene etc. Direct electroreduction of $\mathrm{CO}_{2}$ to ethylene is a promising option which still requires an efficient and high rate conversion. Methanol is also considered as a fuel of the future, along with hydrogen, and it can already be used in internal combustion engines and fuel cells.[52] However, the activity and selectivity of the electrocatalyst towards methanol is still low. [53] Converting $\mathrm{CO}_{2}$ to $\mathrm{CO}$ is a relatively simple and straightforward reaction which only requires transfer of 2 electrons and 2 protons. $\mathrm{CO}_{2}$ can be converted directly to a $\mathrm{CO}$ and $\mathrm{H}_{2}$ mixture by controlling the potential, or $\mathrm{CO}$ and $\mathrm{H}_{2}$ can be produced separately and mixed to the desired ratio to make methanol or synthetic fuel via the Fischer-Tropsch process.[54, 55] FischerTropsch processing is already commercially utilized by Shell in Qatar to produce liquid fuel from syngas. The plant produces 140.000 barrels of liquid fuel per day providing $8 \%$ of Shells worldwide fuel production. Integrating $\mathrm{CO}_{2}$ in the chemical chain with such a technology would enable the usage in the current transportation infrastructure in the form of renewable fuels. However, such process does not only demand an efficient and stable route but should also comparable in cost with existing technologies. Therefore, it is important to find an earth abundant, efficient and stable electrocatalyst for the conversion of $\mathrm{CO}_{2}$ to fuels or fuel type molecules. This eventually requires understanding of both fundamental and engineering aspects of electrochemical $\mathrm{CO}_{2}$ reduction. 


\subsection{Electrochemical $\mathrm{CO}_{2}$ reduction}

Electrochemical reduction of $\mathrm{CO}_{2}$ has been studied for many years starting from the early 70 s while recently many research groups worldwide started to contribute to the field. There are a range of products reported depending on the electrode material and process conditions.[56] Equilibrium potentials for some of these products are listed below.

$$
\begin{gathered}
\mathrm{CO}_{2}+2 \mathrm{H}^{+}+2 e^{-} \longrightarrow \mathrm{CO}+\mathrm{H}_{2} \mathrm{O} \quad E_{0}=-0.103 \mathrm{~V} \\
\mathrm{CO}_{2}+\mathrm{H}^{+}+2 e^{-} \longrightarrow \mathrm{HCOO}^{-}+\mathrm{H}_{2} \mathrm{O} \quad E_{0}=-0.225 \mathrm{~V} \\
\mathrm{CO}_{2}+8 \mathrm{H}^{+}+8 e^{-} \longrightarrow \mathrm{CH}_{4}+2 \mathrm{H}_{2} \mathrm{O} \quad E_{0}=0.169 \mathrm{~V} \\
2 \mathrm{CO}_{2}+12 \mathrm{H}^{+}+12 e^{-} \longrightarrow \mathrm{C}_{2} \mathrm{H}_{4}+4 \mathrm{H}_{2} \mathrm{O} \quad E_{0}=0.079 \mathrm{~V}
\end{gathered}
$$

Thermodynamically methane and ethylene should be produced at low cathodic potentials, yet these products are kinetically hindered. Different pathways were proposed both experimentally and computationally, especially when multiple electron and proton transfers were required. The first step, a proton coupled electron transfer, to form $\mathrm{COOH}$ is a key step since it is usually, but not always, the rate determining step of the overall reaction. $[57,58]$ Homogenous formation of this intermediate requires a very high reduction potential (-1.90 V vs SHE) in aqueous medium. Stabilization of this intermediate therefore is very important to achieve an efficient and high rate electrochemical reduction process. Additionally, the hydrogen evolution reaction (HER) also competes with $\mathrm{CO}_{2}$ reduction in aqueous media, which is very important to suppress, in order to reach high $\mathrm{CO}_{2}$ reduction current densities. By considering the binding energy of the $\mathrm{COOH}$ intermediate and hydrogen one can divide the metals into four different categories. [59]

i) Category 1 metals including $\mathrm{Pb}, \mathrm{Hg}, \mathrm{In}, \mathrm{Cd}$ bind weakly to this intermediate, and yield mostly formic acid.

ii) Category 2 metals including $\mathrm{Au}, \mathrm{Ag}$, and $\mathrm{Zn}$ bind fairly strongly to this intermediate, but can't reduce $\mathrm{CO}$.

iii) Category 3 metals including only copper, show medium binding to this intermediate, and can reduce $\mathrm{CO}$ further to hydrocarbons and alcohols.

iv) Category 4 metals including $\mathrm{Fe}, \mathrm{Pt}$ and $\mathrm{Ni}$, bind to hydrogen fairly strongly and yield very little $\mathrm{CO}_{2}$ reduction products. 


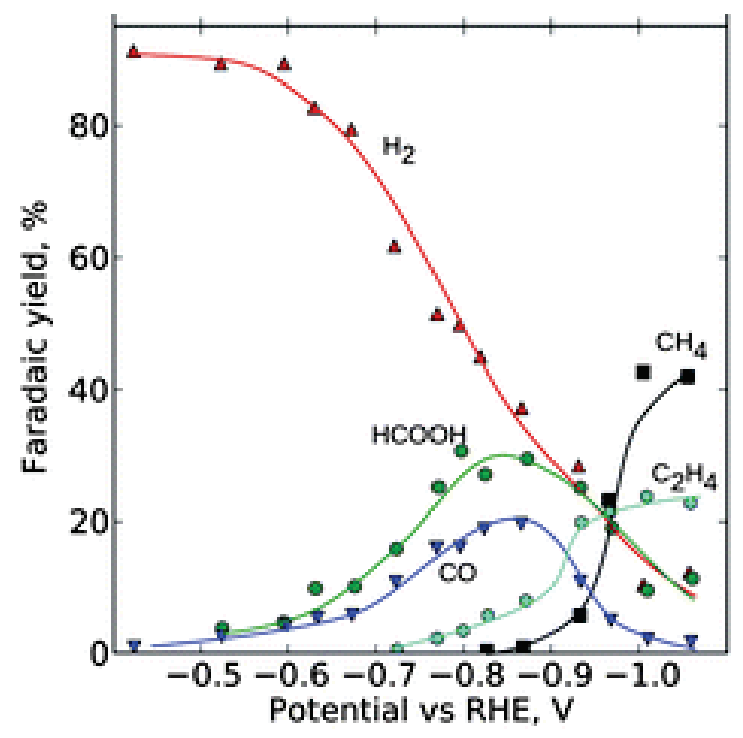

Figure 5: Faradaic efficiency for each product as a function of potential is shown for major products on electropolished smooth copper electrode. ${ }^{61}$

It is important to note that this classification is quite general and relies on the major products of the electrochemical reduction. Recently hydrocarbon and alcohol formation was reported on several transition metals including $\mathrm{Au}, \mathrm{Ag}, \mathrm{Ni}$ and Fe.[60] However the partial current densities of these products are very small and copper can still be considered as the only material that can catalyze $\mathrm{CO}_{2}$ conversion to hydrocarbons with reasonable faradaic efficiencies at ambient pressure and temperature.[56] The product distribution of smooth polycrystalline copper electrode is given in Figure 5. [61] At low potentials, hydrogen production dominates, since $\mathrm{CO}$ and formic acid have onset potentials around $-0.5 \mathrm{~V}$ vs RHE. At higher overpotentials hydrocarbon formation starts, where a difference of $-0.15 \mathrm{~V}$ is recorded between onset potentials of methane and ethylene. Methane is being a dominant product as the potential is decreased below $-1 \mathrm{~V}$ vs. RHE. One of the major challenges for the commercialization of a copper electrocatalyst is the low energy efficiency towards both hydrocarbons and $\mathrm{CO}$ due to the required high overpotentials to get reasonable faradaic efficiencies. Additionally, copper electrodes loose activity within a couple of hours, unless very high purity electrolytes are used. 


\subsection{Thesis Outline}

In this thesis we focus on the formation of $\mathrm{CO}$ and hydrocarbons using rough copper electrodes, which were prepared by electrochemical reduction or high temperature hydrogenation of copper oxides. We investigate the effect of catalyst preparation and process conditions on the selectivity of the electrocatalytic process. Taking into account the chemical nature of the product and the change in catalytic selectivity, we deduced mechanistic information. We reviewed and integrated the current available literature on electrochemical $\mathrm{CO}_{2}$ reduction in our discussions.

Firstly, we hypothesized that the initial crystal orientation of the cuprous oxide might influence the selectivity and explain the contradictory results reported in the literature. In chapter 3, rather than the crystal orientation we discovered that the selectivity of the process is dramatically influenced by the thickness of the initial oxide layer, which affects the loading of the copper nanoparticles and corresponding electrochemically active surface area. We observed production of ethylene with very high ethylene to methane ratios at relatively thin layers of the oxide, whereas ethane formation was observed when the initial oxide layer gets thicker.

In chapter 4, we designed experiments and performed calculations to understand the selective formation of ethylene on mildly roughened surfaces. We investigated the effect of buffering capacity on the selectivity and discovered that rough copper surfaces can also produce appreciable amounts of methane at relatively high buffer capacities. We calculated the $\mathrm{pH}$ near the electrode surface with changing electrolyte concentration and pressure during the electrolysis, and mechanistically interpreted the reaction by means of recent experimental and computational work.

In chapter 5, we designed experiments to understand the formation of ethane on very rough copper surfaces. We discovered ethane is formed by further electrochemical hydrogenation of ethylene on very rough surfaces. The formation of ethane can be suppressed by using strongly adsorbing ions such as iodide, rather than the flow rate of $\mathrm{CO}_{2}$ which influences the residence time of ethylene in the reactor. $\mathrm{A}$ tentative mechanism is proposed for the formation of ethane on very rough copper surfaces.

In Chapter 6, we designed a new type of three-phase electrode with hollow fiber geometry by using catalytic information that we obtained at high pressure studies. We investigated the formation of $\mathrm{CO}$ and formic acid and achieved a total $\mathrm{FE}$ of $85 \%$ at low overpotentials $(200-400 \mathrm{mV})$. The formation of $\mathrm{CO}$ starts just above 
$(\dot{\eta} \approx 40 \mathrm{mV})$ the equilibrium potential which implies a very efficient electrocatalyst. Moreover, due to excellent mass transport properties we achieved 10 fold enhancement in the formation rate of $\mathrm{CO}$ when compared to the best copper electrodes reported in the literature.

Finally we summarize the major findings of our studies and provide a perspective to further improve the formation of $\mathrm{CO}$ and hydrocarbons on structured copper electrodes, in the final chapter.

\subsection{References}

1. Sieminski, A., International Energy Outlook, 2014

2. Kostic, M., Work, power, and energy. Encyclopedia of energy, 2004. 6: p. 527538.

3. Annual Energy Review 2011, U.S. Energy Information Agency Washington, DC, 2011.

4. Stanford global energy and climate project, 2012. Stanford University (2012).

5. Field, C.B., The global carbon cycle: integrating humans, climate, and the natural world. Vol. 62. 2004: Island Press.

6. Petit, J.-R., et al., Climate and atmospheric history of the past 420,000 years from the Vostok ice core, Antarctica. Nature, 1999. 399(6735): p. 429-436.

7. Oreskes, N., The scientific consensus on climate change. Science, 2004. 306(5702): p. 1686-1686.

8. CO2now.org, Current Data for Atmospheric $\mathrm{CO}_{2}$.

9. Canadell, J.G., et al., Contributions to accelerating atmospheric $\mathrm{CO}_{2}$ growth from economic activity, carbon intensity, and efficiency of natural sinks. Proceedings of the national academy of sciences, 2007. 104(47): p. 18866-18870.

10. Hoffman, D.L. and A. Simmons, The Resilient Earth. Reply to Comment, 2008.

11. Priestley, J., Directions for Impregnating Water with Fixed Air: In Order to Communicate to it the Peculiar Spirit and Virtues of Pyrmont Water, and Other Mineral Waters of a Similar Nature1774: J. Johnson.

12. Arrhenius, S., XXXI. On the influence of carbonic acid in the air upon the temperature of the ground. The London, Edinburgh, and Dublin Philosophical Magazine and Journal of Science, 1896. 41(251): p. 237-276.

13. Miller, F.P., A.F. Vandome, and J. McBrewster, Global Dimming2009: Alphascript Publishing.

14. Gray, L.J., et al., Solar influences on climate. Reviews of Geophysics, 2010. 48(4).

15. Tyson, N.d., Cosmos: A Spacetime Odyssey, Episode 12: The World Set Free.

16. http://www.nasa.gov/centers/goddard/home/index.html. 
17. Chen, J., C. Wilson, and B. Tapley, Satellite gravity measurements confirm accelerated melting of Greenland ice sheet. Science, 2006. 313(5795): p. 19581960.

18. Luthcke, S.B., et al., Recent Greenland ice mass loss by drainage system from satellite gravity observations. Science, 2006. 314(5803): p. 1286-1289.

19. King, M.A., et al., Lower satellite-gravimetry estimates of Antarctic sea-level contribution. Nature, 2012.491(7425): p. 586-589.

20. Pfeffer, W.T., J. Harper, and S. O'Neel, Kinematic constraints on glacier contributions to 21st-century sea-level rise. Science, 2008. 321(5894): p. 13401343.

21. Vermeer, M. and S. Rahmstorf, Global sea level linked to global temperature. Proceedings of the national academy of sciences, 2009. 106(51): p. 21527-21532.

22. "Ranking of the world's citieis most exposed to coastal flooding today and in the future" Executive Summary. Organisation for Economic Co-operation and Development (OECD), France

23. Gosling, S.N., et al., Climate: Observations, projections and impacts. Climate: Observations, projections and impacts, 2011.

24. Feely, R.A., et al., Evidence for upwelling of corrosive" acidified" water onto the continental shelf. Science, 2008. 320(5882): p. 1490-1492.

25. Hoegh-Guldberg, O., et al., Coral reefs under rapid climate change and ocean acidification. Science, 2007. 318(5857): p. 1737-1742.

26. Buitenwerf, R, L. Rose, and S.I. Higgins, Three decades of multi-dimensional change in global leaf phenology. Nature Climate Change, 2015.

27. Root, T.L., et al., Fingerprints of global warming on wild animals and plants. Nature, 2003. 421(6918): p. 57-60.

28. Walter, K.M., et al., Methane bubbling from Siberian thaw lakes as a positive feedback to climate warming. Nature, 2006. 443(7107): p. 71-75.

29. http://www.nasa.gov/topics/earth/features/vapor_warming.html.

30. Aresta, M., Carbon dioxide as chemical feedstock2010: John Wiley \& Sons.

31. Van de Krol, R. and M. Grätzel, Photoelectrochemical hydrogen production2012: Springer.

32. Bentley, R.W., Global oil \& gas depletion: an overview. Energy Policy, 2002. 30(3): p. 189-205.

33. Outlook, A.E., Energy Information Administration. Department of Energy, 2010.

34. Aresta, M., Carbon dioxide recovery and utilization2003: Springer Science \& Business Media.

35. Blankenship, R.E., et al., Comparing photosynthetic and photovoltaic efficiencies and recognizing the potential for improvement. Science, 2011. 332(6031): p. 805-809. 
36. Li, C.W., J. Ciston, and M.W. Kanan, Electroreduction of carbon monoxide to liquid fuel on oxide-derived nanocrystalline copper. Nature, 2014. 508(7497): p. 504-507.

37. Whipple, D.T. and P.J. Kenis, Prospects of $\mathrm{CO}_{2}$ utilization via direct heterogeneous electrochemical reduction. The Journal of Physical Chemistry Letters, 2010. 1(24): p. 3451-3458.

38. Cartlidge, E., Saving for a rainy day. Science, 2011. 334(6058): p. 922-924.

39. Turner, J.A., A realizable renewable energy future. Science, 1999. 285(5428): p. 687-689.

40. Makhijani A, M.C., Ramana MV, Institute for Energy and Environmental Research (IEER), 2012.

41. The World Wind Energy Association Half-year Report. WWEA. pp. 1-8., 2014.

42. Global Market Outlook for Solar Power, Solar Power Europe (SPE), 2015.

43. Osmundsen, T., IEA and Solar PV: Two World's Apart, 2014, Norwegian Climate Foundation Report.

44. Milborrow, D. The real costs and problems of integrating wind. in BLOWING Network Workshop, Belfast, January 2001. 2001.

45. Kim, B., et al., Influence of dilute feed and $\mathrm{pH}$ on electrochemical reduction of $\mathrm{CO}$ 2 to $\mathrm{CO}$ on $\mathrm{Ag}$ in a continuous flow electrolyzer. Electrochimica Acta, 2015. 166: p. 271-276.

46. Goeppert, A., et al., Air as the renewable carbon source of the future: an overview of CO 2 capture from the atmosphere. Energy \& Environmental Science, 2012. 5(7): p. 7833-7853.

47. Lackner, K.S., Capture of carbon dioxide from ambient air. The European Physical Journal Special Topics, 2009. 176(1): p. 93-106.

48. Herzog, H., Assessing the Feasibility of Capturing $\mathrm{CO}_{2}$ from the Air, 2003, MIT Laboratory for Energy and the Environment, Massachusetts Institute of Techology, Cambridge, MA.

49. van der Giesen, C., R. Kleijn, and G.J. Kramer, Energy and climate impacts of producing synthetic hydrocarbon fuels from $\mathrm{CO} 2$. Environmental science \& technology, 2014. 48(12): p. 7111-7121.

50. Kruse, B., S. Grinna, and C. Buch, Hydrogen: Status og muligheter. Trans. Bjørnar Kruse. Bellona, USA: The Bellona Foundation. N. pag. PDF file, 2002.

51. Zhu, S. and M. Shao, Surface structure and composition effects on electrochemical reduction of carbon dioxide. Journal of Solid State Electrochemistry, 2015: p. 113.

52. Goeppert, A., et al., Recycling of carbon dioxide to methanol and derived products-closing the loop. Chemical Society Reviews, 2014. 43(23): p. 79958048 . 
53. Albo, J., et al., Towards the electrochemical conversion of carbon dioxide into methanol. Green Chemistry, 2015. 17(4): p. 2304-2324.

54. Delacourt, C., et al., Design of an electrochemical cell making syngas ( $\mathrm{CO}+\mathrm{H} 2)$ from $\mathrm{CO} 2$ and $\mathrm{H} 2 \mathrm{O}$ reduction at room temperature. Journal of The Electrochemical Society, 2008. 155(1): p. B42-B49.

55. Zhan, Z., et al., Syngas production by coelectrolysis of $\mathrm{CO}_{2} / \mathrm{H} 2 \mathrm{O}$ : the basis for a renewable energy cycle. Energy \& Fuels, 2009. 23(6): p. 3089-3096.

56. Hori, Y., Electrochemical $\mathrm{CO}_{2}$ reduction on metal electrodes, in Modern aspects of electrochemistry2008, Springer. p. 89-189.

57. Peterson, A.A., et al., How copper catalyzes the electroreduction of carbon dioxide into hydrocarbon fuels. Energy \& Environmental Science, 2010. 3(9): p. 13111315.

58. Peterson, A.A. and J.K. Nørskov, Activity descriptors for $\mathrm{CO}_{2}$ electroreduction to methane on transition-metal catalysts. The Journal of Physical Chemistry Letters, 2012. 3(2): p. 251-258.

59. Jones, J.P., G. Prakash, and G.A. Olah, Electrochemical $\mathrm{CO}_{2}$ Reduction: Recent Advances and Current Trends. Israel Journal of Chemistry, 2014. 54(10): p. 1451-1466.

60. Kuhl, K.P., et al., Electrocatalytic conversion of carbon dioxide to methane and methanol on transition metal surfaces. Journal of the American Chemical Society, 2014. 136(40): p. 14107-14113.

61. Kuhl, K.P., et al., New insights into the electrochemical reduction of carbon dioxide on metallic copper surfaces. Energy \& Environmental Science, 2012. 5(5): p. 7050-7059. 



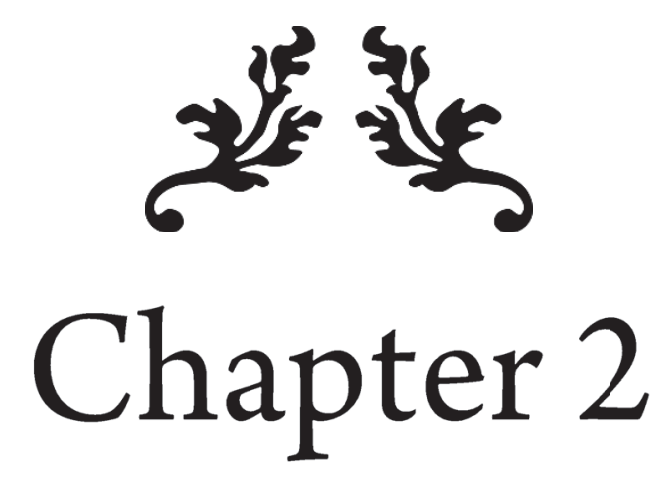

Experimental Setup and Procedures

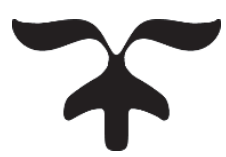




\subsection{Electrodeposition of $\mathrm{Cu}_{2} \mathrm{O}$ films}

All working solutions were prepared and all glassware cleaned using deionized water (Millipore MilliQ, $18.2 \mathrm{M} \Omega \mathrm{cm})$. Cuprous oxide $\left(\mathrm{Cu}_{2} \mathrm{O}\right)$ films were electrodeposited onto copper plates (Alfa Aesar, 99.99\%) from $\mathrm{Cu}^{2+}$ containing solutions prepared using $0.4 \mathrm{M} \mathrm{CuSO}_{4}$ (Sigma Aldrich, $\geq 99 \%$ ) and 3 or $4 \mathrm{M}$ lactic acid (Sigma Aldrich) at 60 or $70{ }^{\circ} \mathrm{C}$, according to the procedures described elsewhere.[2] The $\mathrm{pH}$ of the solution was carefully adjusted between 9 and 12 using solid $\mathrm{NaOH}$ (Sigma Aldrich, 98\%) and a $1 \mathrm{M} \mathrm{NaOH}$ solution. Copper plates were prepared by mechanical polishing using emery paper, followed by cleaning ultrasonically in ethanol and water. The electrodeposition was conducted in a standard three-electrode cell where platinum mesh and $\mathrm{Ag} / \mathrm{AgCl}$ in $3 \mathrm{M} \mathrm{NaCl}$ served as counter and reference electrodes, respectively (Figure 1). Galvanostatic deposition was performed at 0.8 or $2 \mathrm{~mA} \mathrm{~cm}^{-2}$ using a potentiostat/galvanostat (PAR, Versastat 3). Specifically, the crystalline morphology was controlled by adapting experimental parameters. $\mathrm{Cu}_{2} \mathrm{O}$ films were deposited using a molar lactic acid (LA)/ $\mathrm{Cu}^{2+}$ ratio of 10 and 7.5 at $\mathrm{pH} 12$ and $\mathrm{pH}$ 9, respectively. The deposition times of the films varies depending on the current density applied. Deposition was continued until a total charge of $7 \mathrm{C} \mathrm{cm}^{-2}$ was passed through the cell for all samples. Series of [110] oriented films were prepared by passing a variable amount of total electrical charge through the electrochemical cell $\left.(0.8 \mathrm{~mA} \mathrm{~cm})^{-2}\right)$, ranging from 3 to $11 \mathrm{C} \mathrm{cm}^{-2}$ to control the thickness of the film. The crystalline phase of the films was determined using X-ray diffraction (a Bruker D2

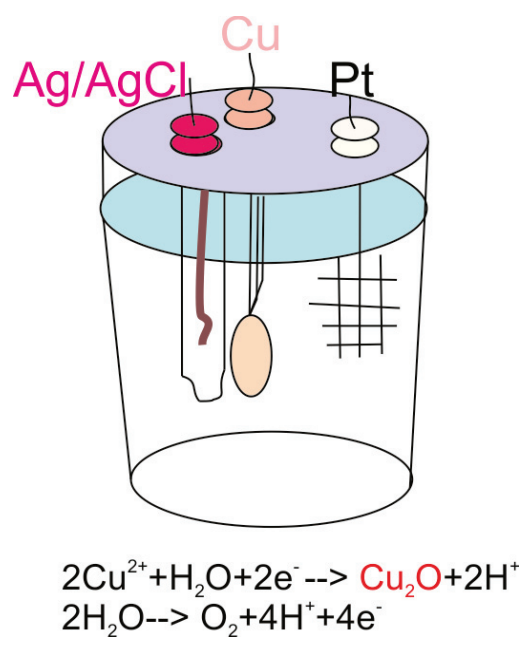

Figure 1: Sketch of the experimental setup used for electrodeposition of $\mathrm{Cu}_{2} \mathrm{O}$ 
Phaser, equipped with a $\mathrm{Cu}-\mathrm{K} \alpha$ radiation source operating at $30 \mathrm{kV}$ and $10 \mathrm{~mA}$ ). Scanning Electron Microscope (SEM) images were taken using a Phillips FEI XL30 FEG-ESEM and FEI Sirion HR-SEM.

\subsection{Electrochemical $\mathrm{CO}_{2}$ reduction experiments at ambient}

\section{pressure}

Electrochemical $\mathrm{CO}_{2}$ reduction was carried out in a glass cell (Figure 2) using a three electrode assembly at room temperature and pressure. $85 \mathrm{ml}$ of $0.1 \mathrm{M} \mathrm{KHCO}_{3}$ (Sigma Aldrich, 99.99\%) was used as electrolyte at $\mathrm{pH} 6.8$, as obtained after saturation with $\mathrm{CO}_{2}$ (Linde Gas Benelux 99.99\%). Pt mesh was used as counter electrode and was separated from the working electrode using a proton exchange Nafion 112 membrane (Sigma Aldrich). $\mathrm{Ag} / \mathrm{AgCl}$ in $3 \mathrm{M} \mathrm{NaCl}$ was used as a reference electrode and potentials were recalculated with reference to the Reversible Hydrogen Electrode (RHE) scale after the experiments. $\mathrm{CO}_{2}$ was continuously purged at a rate of $20 \mathrm{ml}$ $\min ^{-1}$ for 30 minutes before each experiment, to attain saturation of the electrolyte. Then the flow rate was decreased to $5 \mathrm{ml} \mathrm{min}^{-1}$, during which electrochemical reduction was conducted. The continuously purged headspace of the reactor was

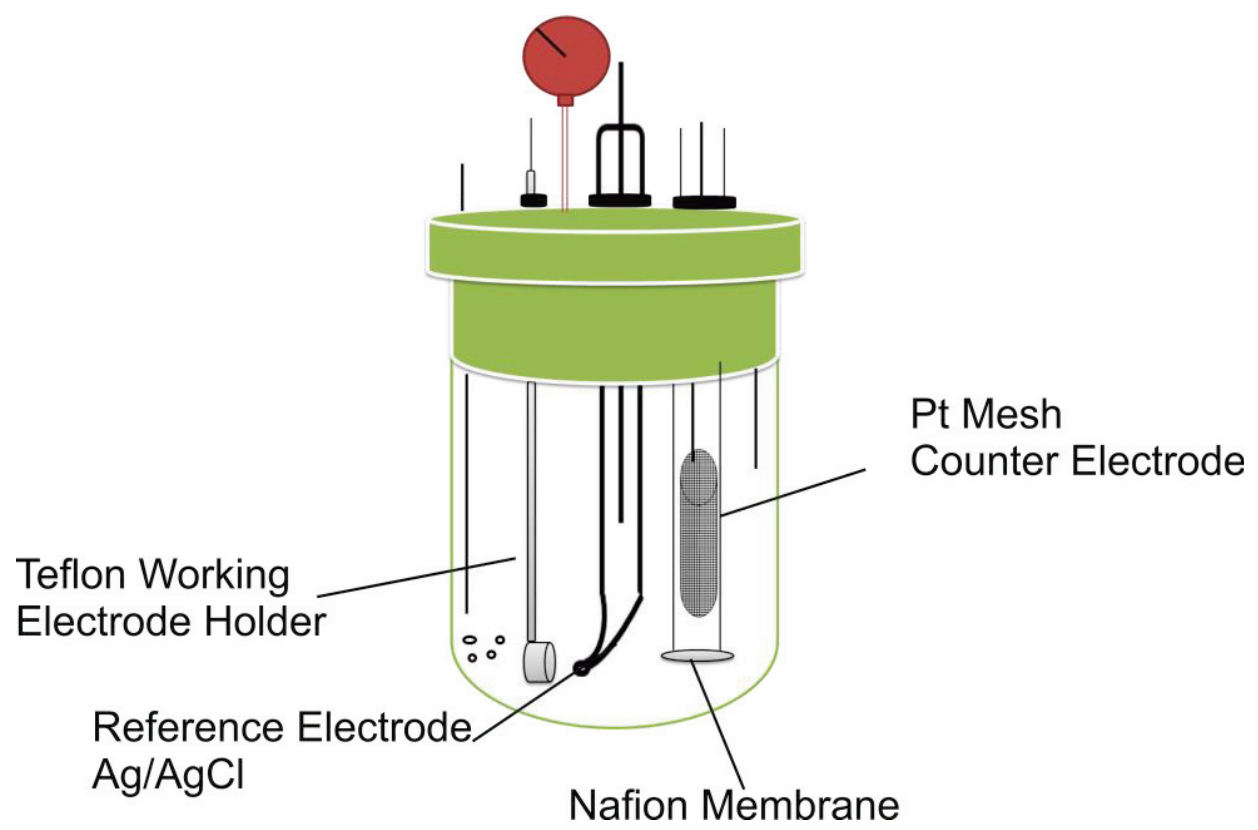

Figure 2: Sketch of the experimental setup used for ambient pressure electrochemical $\mathrm{CO}_{2}$ reduction experiments 
approximately $45 \mathrm{ml}$ and the reactor effluent sampled directly via gas chromatography (GC) once every $6 \mathrm{~min}$. The GC was equipped with two different columns (ShinCarbon $2 \mathrm{~m}$ micropacked column and Rtx-1) for simultaneous separation of CO, $\mathrm{CO}_{2}, \mathrm{H}_{2}$ and hydrocarbons. A thermal conductivity detector (TCD) and flame ionization detector (FID) were used to perform the quantitative analysis of the gas phase products. The time needed to reach the steady state concentration was approximately 40 minutes, so all experiments were conducted for at least 1 hour before gas phase measurement. A control cathodic experiment was conducted at -1.1 V vs. RHE by purging $\mathrm{N}_{2}$ through the reactor since the decomposition of organics associated with the electrodeposition can also yield hydrocarbons. No hydrocarbon or $\mathrm{CO}$ formation were detected in the absence of $\mathrm{CO}_{2}$. Liquid products formed during the electrolysis were analyzed off line using High Performance Liquid Chromatography (HPLC) (Prominence HPLC, Shimadzu; Aminex HPX 87-H column, Biorad).

\subsection{Electrochemical $\mathrm{CO}_{2}$ reduction experiments at high pressures}

Cuprous oxide films were electrodeposited onto copper plates (Alfa Aesar, $99.99 \%$ ) from aqueous $\mathrm{Cu}^{2+}$ containing solutions prepared using $0.4 \mathrm{M} \mathrm{CuSO}_{4}$ (Sigma Aldrich, $\geq 99 \%$ ) and $4 \mathrm{M}$ lactic acid (Sigma Aldrich) at $60{ }^{\circ} \mathrm{C}$. The $\mathrm{pH}$ of the solution was carefully adjusted to $\mathrm{pH} 12$ using solid $\mathrm{NaOH}$ pellets (Sigma Aldrich, 98\%) and a $1 \mathrm{M}$ $\mathrm{NaOH}$ solution. After the electrodeposition the oxide films were reduced back to copper at an applied potential of $-1.2 \mathrm{~V}$ vs $\mathrm{Ag} / \mathrm{AgCl}$ in $\mathrm{CO}_{2}$ saturated $0.1 \mathrm{M} \mathrm{KHCO}_{3}$ (99.99\%, Sigma Aldrich). The potential ( $0.6 \mathrm{~V}$ vs. $\mathrm{RHE}$ ) is enough to reduce $\mathrm{Cu}_{2} \mathrm{O}$ back to copper which starts around $0.3 \mathrm{~V}$ vs. RHE. Continuous electrochemical reduction experiments were carried out in a stainless steel autoclave under continuous stirring at $600 \mathrm{rpm}$ with a magnetic stirrer where the complete operation system is given in Figure 3. Pt mesh was used as counter electrode and was separated from the working electrode using a proton exchange Nafion 112 membrane (Sigma Aldrich). A homemade $\mathrm{Ag} / \mathrm{AgCl}$ in $3 \mathrm{M} \mathrm{KCl}$ was used as a reference electrode which was refreshed and calibrated each week against a reversible hydrogen electrode (RHE). The potentials were corrected after the experiment for IR-drop caused by the uncompensated resistances of the electrolyte. A $50 \mathrm{ml} / \mathrm{min}$ flow rate of $\mathrm{CO}_{2}$ (Linde Gas Benelux 99.99\%) was used before and during the reduction process. The reactor effluent was sampled by Gas Chromatography (GC) every 6 minutes. A thermal conductivity detector (TCD) and flame ionization detector (FID) were used to quantitatively analyze the gas phase products. The time needed to reach the steady state concentration was varying in the range of $25-45$ minutes depending on the 


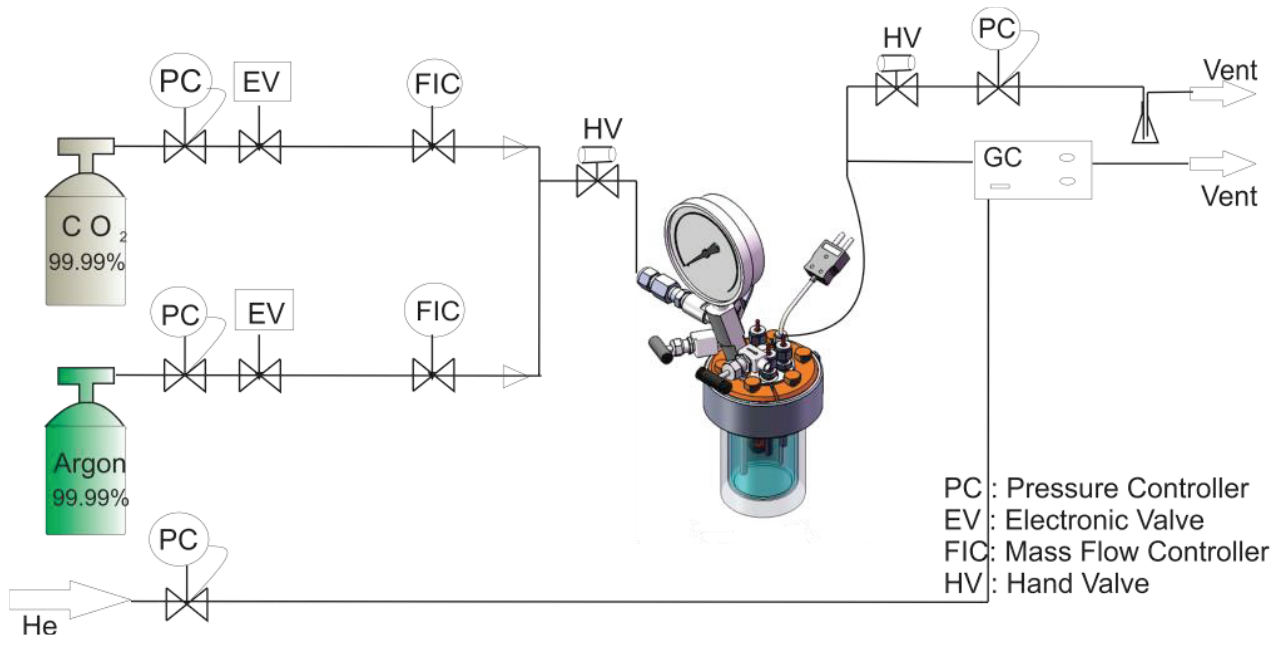

Figure 3: Schematic depiction of the pressurized reactor and additional equipment used for continuous electrochemical reduction of $\mathrm{CO}_{2}$

pressure, so all experiments were conducted for at least 90 minutes. Liquid products formed during the electrolysis were analyzed by extracting samples of the electrolyte after reaction, and using High Performance Liquid Chromatography (HPLC) (Prominence HPLC, Shimadzu; Aminex HPX 87-H column, Biorad).

\subsection{Online electrochemical mass spectroscopy measurements}

Online electrochemical mass spectroscopy (OLEMS) was used to evaluate onset potentials of volatile products formed during $\mathrm{CO}_{2}$ reduction. Using OLEMS, the formation and consumption of stable intermediates were monitored while sweeping the potential. A schematic drawing of the OLEMS setup is given in Figure 4. The products were collected with a small hydrophobic tip that was positioned close to the electrode (about $10 \mu \mathrm{m}$ ). A Polyether ether ketone (PEEK) capillary is used to connect the mass spectrometry chamber to the tip which is made of a porous cylinder. The tip was constructed as a porous Teflon cylinder with a diameter of $0.5 \mathrm{~mm}$ and an average pore size of 10-14 $\mu \mathrm{m}$ in a Kel-F holder. Before each experiment the tip was cleaned in a solution of $0.2 \mathrm{M} \mathrm{K}_{2} \mathrm{Cr}_{2} \mathrm{O}_{7}$ in $2 \mathrm{M} \mathrm{H}_{2} \mathrm{SO}_{4}$ and rinsed thoroughly with water. A secondary electron multiplier voltage of $2,400 \mathrm{~V}$ was used for detection of products in a Balzers quadrupole mass spectrometer, except for hydrogen where a secondary electron multiplier voltage of $1,200 \mathrm{~V}$ was used. The products were measured while changing the potential of the electrode from $0.0 \mathrm{~V}$ to $-1.5 \mathrm{~V}$ vs. RHE and back at $1 \mathrm{mV}$ 


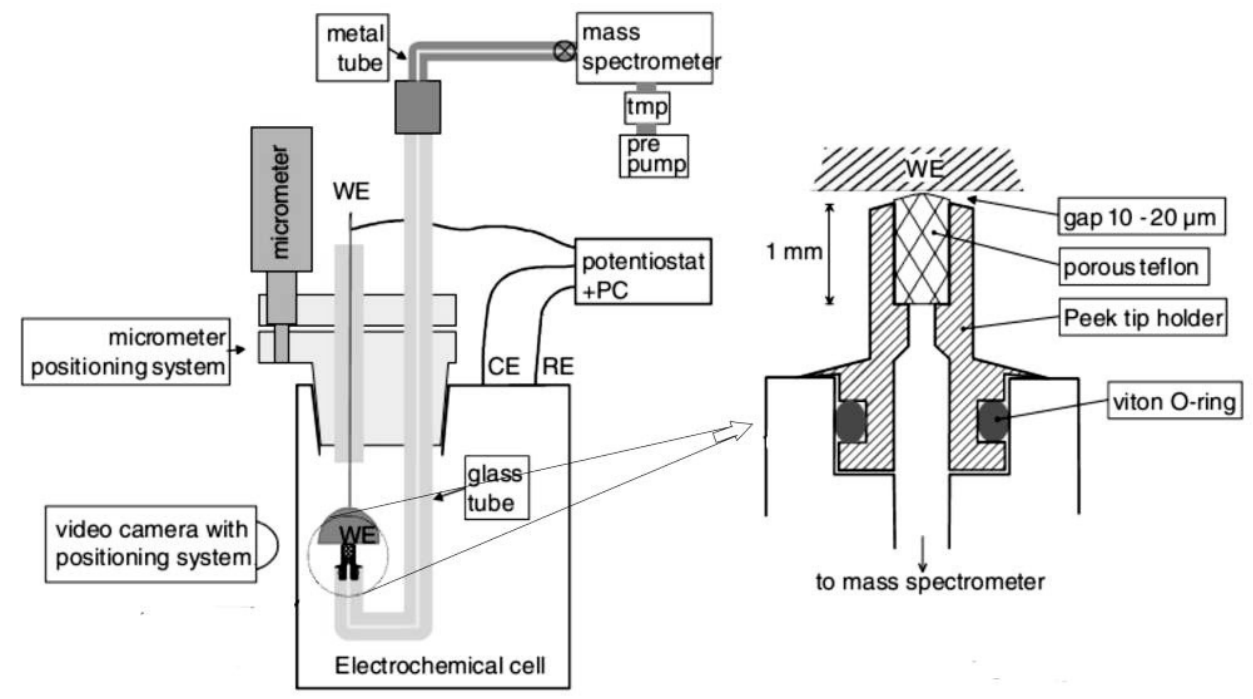

Figure 4: Schematic drawing of the OLEMS setup. The inset figure shows the tip of the mass spectrometer in detail. WE, CE, and RE stand for working, counter and reference electrode respectively. Tmp stands for turbo molecular pump. Picture adapted from reference.[1]

$\mathrm{s}^{-}$. In addition to formic acid detected by HPLC, mass fragments corresponding to aldehydes and alcohols could be detected by OLEMS.

\subsection{Preparation of Cu Hollow Fibers}

Commercial available copper powder (Skyspring nanomaterials, 99\%) with particle size of 1-2 $\mu \mathrm{m}$ was used as catalyst precursor. N-methylpyrrolidone (NMP, 99.5 WT\%, Sigma Aldrich), and Polyetherimide (PEI, Ultem 1000, General Electric) were used as solvent and polymer respectively. Copper powder (71.09 wt \%) was added to the NMP (22.14 wt \%) followed by stirring and ultrasonic treatment for $30 \mathrm{~min}$. After addition of $\operatorname{PEI}(6.76 \mathrm{wt} \%)$ this mixture was heated and kept at $50{ }^{\circ} \mathrm{C}$ and $60^{\circ} \mathrm{C}$ for 30 minutes and 2 hours, respectively. Next, the solution was allowed to cool down by stirring overnight which is followed by degassing. Vacuum was applied for $90 \mathrm{~min}$ and the mixture was left overnight.

Spinning was carried out at room temperature $\left(21 \pm 3^{\circ} \mathrm{C}\right)$ using a stainless steel vessel, that was pressurized to 1 bar using nitrogen. The mixture was pressed through a spinneret (inner and outer diameters of $0.8 \mathrm{~mm}$ and $2.0 \mathrm{~mm}$, respectively) into a coagulation bath containing tap water. Deionized water was pumped through the bore of the spinneret with a speed of $30 \mathrm{ml} \mathrm{min}^{-1}$ and the air gap was set to $1 \mathrm{~cm}$. 
After spinning the fibers were kept in the coagulation bath for 1 day to remove traces of NMP, followed by drying for 1 day. The green copper hollow fibers were thermally treated at $600^{\circ} \mathrm{C}$ for 3 hours (heating rate and cooling rates: $1^{\circ} \mathrm{C} \mathrm{min}-1$ ) in air to remove the PEI and induce sintering of the copper particles. The oxidized hollow fibers were reduced by hydrogenation at $280{ }^{\circ} \mathrm{C}$ for 1 hour $\left(\mathrm{H}_{2}\right.$ in Argon: $4 \%$, heating rate and cooling rate: $100^{\circ} \mathrm{C} / \mathrm{min}$ ). X-ray diffraction patterns were collected by using a Bruker D2 Phaser $\mathrm{x}$-ray diffractometer, equipped with a $\mathrm{Cu}-\mathrm{Ka}$ radiation source and operated at $30 \mathrm{kV}$ and $10 \mathrm{~mA}$. SEM images were taken using a Phillips FEI XL30 FEG-ESEM or FEI Sirion HR-SEM.

\subsection{Electrochemical $\mathrm{CO}_{2}$ reduction setup for Copper hollow}

\section{fibers}

All solutions were prepared and all glassware were cleaned by using deionized water (Millipore MilliQ, 18.2 M $\Omega$ ). Electrochemical $\mathrm{CO}_{2}$ reduction activity of $\mathrm{Cu} \mathrm{HF}$ 's was measured by using a three electrode assembly in a glass cell at room temperature and pressures (Figure 5). A Princeton Applied Research versaSTAT 3 potentiostat was

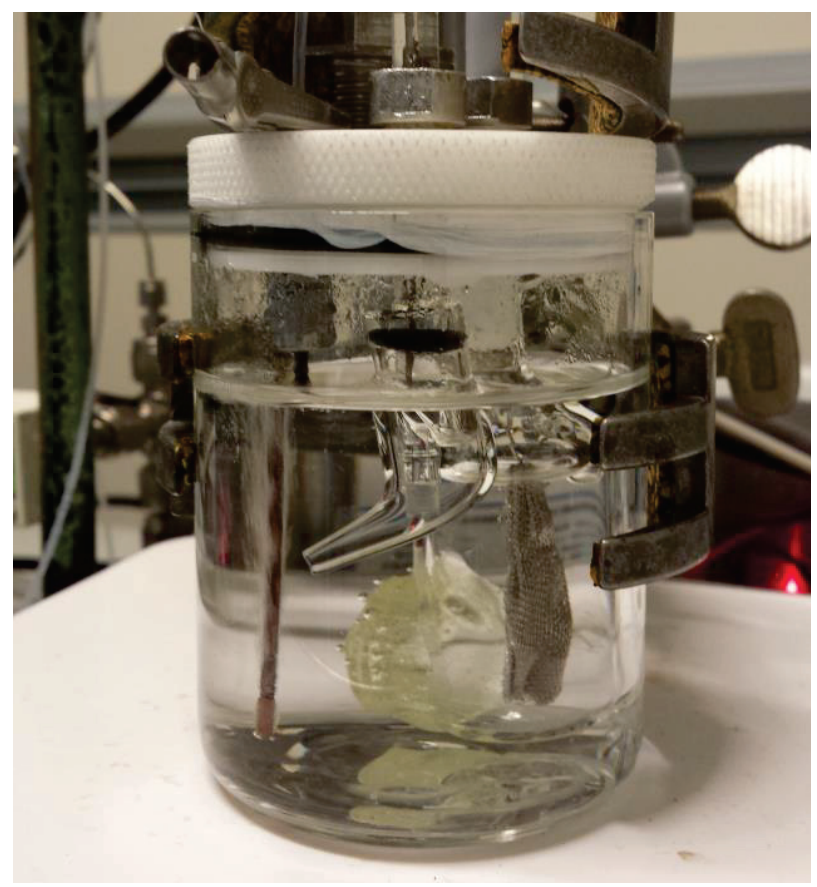

Figure 5: Experimental setup and glassware used to evaluate the electrochemical performance of the $\mathrm{Cu}$ hollow fibers. 
used to control the potentials. The counter electrode, Pt mesh, was separated by using a Nafion 112 membrane (Sigma Aldrich). $\mathrm{Ag} / \mathrm{AgCl}$ (3 M NaCl BASI) reference electrode was placed near the working electrode by using a Luggin capillary and all the potentials were converted to RHE scale afterwards (Figure 5). IR drops were measured before the electrolysis and compensated manually after the experiments. $4 \pm 0.5 \mathrm{~cm}$ long $\mathrm{Cu} \mathrm{HF}$ samples were used as both working electrode and as gas diffuser. The fibers were sealed from the bottom by using epoxy glue and connected to the gas inlet of the cell. The cathodic compartment was filled with $100 \mathrm{ml}, 0.3 \mathrm{M} \mathrm{KHCO}_{3}$ (99.95\%, Sigma Aldrich) and purged with $\mathrm{CO}_{2}$ at least 20 minutes before the experiments. During the electrolysis the $\mathrm{CO}_{2}$ was purged continuously through the fiber with $20 \mathrm{ml} \mathrm{min}^{-1}$ unless otherwise indicated, and sampled via gas chromatography (GC) each 6 minutes. $\mathrm{CO}$, $\mathrm{CO}_{2}, \mathrm{H}_{2}$ and hydrocarbons were analyzed with a GC, equipped with two different columns (ShinCarbon $2 \mathrm{~m}$ micropacked column and Rtx-1). A thermal conductivity detector (TCD) and flame ionization detector (FID) were used to perform the quantitative analysis of the gas phase products. The time needed to reach steady state concentration was approximately 10 minutes so all the reaction conditions were kept constant for at least 20 minutes. A control experiment was conducted at $-0.5 \mathrm{~V}$ vs RHE under Argon atmosphere. No $\mathrm{CO}$ was detected that might associated with the organic residues remaining from polymers used during preparation of the hollow fibers. Liquid products formed during the electrolysis were analyzed by using High Performance Liquid Chromatography (HPLC) (Prominence HPLC, Shimadzu; Aminex HPX 87H column, Biorad).

\subsection{Faradaic efficiency calculation}

The Faradaic efficiency (FE) of the electrochemical production was calculated as

$$
F E(\%)=\frac{n_{i} F \phi_{i} F_{m}}{I}
$$

Where $n_{i}$ is the number of the electrons needed for $\mathrm{CO}_{2}$ reduction, $\mathrm{F}$ is the Faraday constant, $\phi_{\mathrm{i}}$ is the volume fraction of the gases, $\mathrm{I}$ is the current obtained and $\mathrm{F}_{\mathrm{m}}$ is the molar $\mathrm{CO}_{2}$ gas flow rate. The number of electrons associated with reduction are 2, 8 , 12 , and 14 for formation of $\mathrm{CO}$, methane, ethylene, and ethane, respectively. The volume fraction of the gases was calculated by calibrating the gas chromatogram (GC) using a diluted mixture of gases of known concentrations. 


\subsection{Electrochemical surface area measurements}

The relative surface roughness factors were estimated by measuring the relative capacitance values in $0.5 \mathrm{M} \mathrm{H}_{2} \mathrm{SO}_{4}$. In a three electrode arrangement, Pt mesh and $\mathrm{Ag} / \mathrm{AgCl}$ electrodes served as counter and reference electrodes respectively. After reducing the cuprous oxide film in $0.1 \mathrm{M} \mathrm{KHCO}_{3}$, cyclic voltammetry (CV) curves were obtained by sweeping the potential in a range where non-faradaic processes occur. The relative surface factor of the nanoparticulate surface compared to bare copper was calculated from the slope of the current density vs the scan rate.

\subsection{Calculations for the concentration of species near the electrode surface}

For the calculation of the local concentration of the species near the electrode surface a numerical approach used by Gupta et al. was adapted.[3] When $\mathrm{CO}_{2}$ is introduced into the solution, the following series of equilibrium reactions takes place:

$$
\begin{gathered}
\mathrm{CO}_{2(a q)} \stackrel{\mathrm{H}_{2} \mathrm{O}}{\longrightarrow} \mathrm{H}_{2} \mathrm{CO}_{3(a q)} \stackrel{\mathrm{H}_{2} \mathrm{O}}{\longrightarrow} \mathrm{HCO}_{3(a q)}^{-}+\mathrm{H}_{3} \mathrm{O}^{+} \\
\mathrm{HCO}_{3(a q)}^{-} \stackrel{\mathrm{H}_{2} \mathrm{O}}{\longrightarrow} \mathrm{CO}_{3(a q)}^{2-}+\mathrm{H}_{3} \mathrm{O}^{+}
\end{gathered}
$$

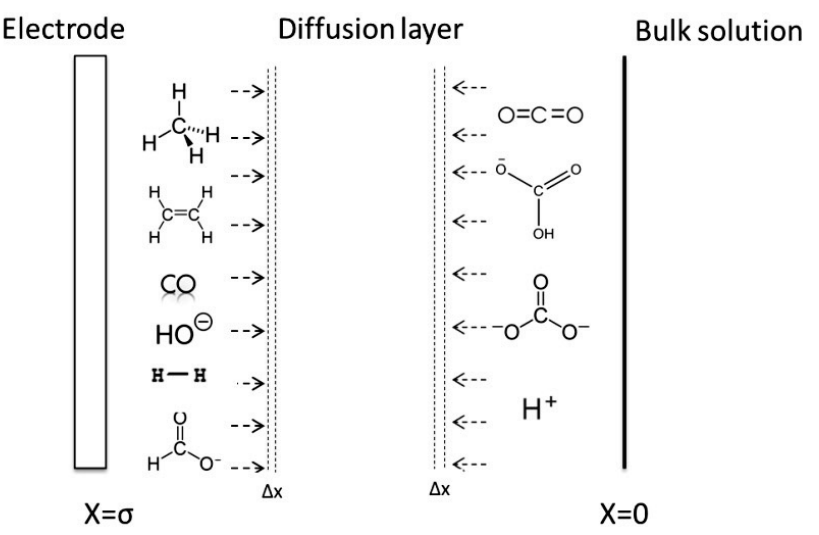

Figure 6: Molecules produced and consumed within the diffusion layer and across the electrode solution interface 
Schematic representation of the electrode solution interface for electrochemical $\mathrm{CO}_{2}$ reduction in bicarbonate solution is given in Figure 6. As the electrolysis starts, $\mathrm{CO}_{2}$ and water react at the electrode surface and form hydroxide ions in the following reactions.

$$
\begin{gathered}
\mathrm{CO}_{2}+\mathrm{H}_{2} \mathrm{O}+2 e^{-} \longrightarrow \mathrm{CO}+2 \mathrm{OH}^{-} \\
\mathrm{CO}_{2}+\mathrm{H}_{2} \mathrm{O}+2 e^{-} \longrightarrow \mathrm{HCOO}^{-}+\mathrm{OH}^{-} \\
\mathrm{CO}_{2}+6 \mathrm{H}_{2} \mathrm{O}+8 e^{-} \longrightarrow \mathrm{CH}_{4}+8 \mathrm{OH}^{-} \\
2 \mathrm{CO}_{2}+8 \mathrm{H}_{2} \mathrm{O}+12 e^{-} \longrightarrow \mathrm{C}_{2} \mathrm{H}_{4}+12 \mathrm{OH}^{-}
\end{gathered}
$$

As $\mathrm{CO}_{2}$ reacts on the electrode, the products diffuse away from the surface to the bulk solution and the reactants diffuse from the bulk solution to the electrode. The reactions with water and bicarbonate ions in solution are relatively slow when compared to the reaction of hydroxyl ions with $\mathrm{CO}_{2}$ and bicarbonate ion. So the following reactions dominates the overall $\mathrm{pH}$ near the electrode surface.

$$
\mathrm{CO}_{2(a q)}+\mathrm{OH}^{-} \underset{k 1}{\longleftrightarrow} \mathrm{HCO}_{3(a q)}^{-}+\mathrm{OH}^{-} \underset{k 2}{\longleftrightarrow} \mathrm{CO}_{3(a q)}^{2-}+\mathrm{H}_{2} \mathrm{O}
$$

By considering a purely diffusional model and rate constant of the forward $\left(k 1_{f}\right.$ and $\left.k 2_{f}\right)$ and backward $\left(k 1_{b}\right.$ and $\left.k 2_{b}\right)$ reactions, the following differential equations can be written.

$\frac{\partial\left[\mathrm{CO}_{2}\right]}{\partial t}=D_{\mathrm{CO}_{2}} \frac{\partial^{2}\left[\mathrm{CO}_{2}\right]}{\partial x^{2}}-\left[\mathrm{CO}_{2}\right]\left[\mathrm{OH}^{-}\right] k 1_{f}+\left[\mathrm{HCO}_{3}^{-}\right] k 1_{r}$

$\frac{\partial\left[\mathrm{HCO}_{3}^{-}\right]}{\partial t}=D_{\mathrm{HCO}_{3}^{-}} \frac{\partial^{2}\left[\mathrm{HCO}_{3}^{-}\right]}{\partial x^{2}}+\left[\mathrm{CO}_{2}\right]\left[\mathrm{OH}^{-}\right] k 1_{f}-\left[\mathrm{HCO}_{3}^{-}\right] k 1_{r}-$ $\left[\mathrm{HCO}_{3}^{-}\right]\left[\mathrm{OH}^{-}\right] k 2_{f}+\left[\mathrm{CO}_{3}^{2-}\right] k 2_{r}$

$\frac{\partial\left[\mathrm{CO}_{3}^{2-}\right]}{\partial t}=D_{\mathrm{CO}_{3}^{2-}} \frac{\partial^{2}\left[\mathrm{CO}_{3}^{2-}\right]}{\partial x^{2}}+\left[\mathrm{HCO}_{3}^{-}\right]\left[\mathrm{OH}^{-}\right] k 2_{f}-\left[\mathrm{CO}_{3}^{2-}\right] k 2_{r}$

$\frac{\partial\left[\mathrm{OH}^{-}\right]}{\partial t}=D_{O H^{-}} \frac{\partial^{2}\left[\mathrm{OH}^{-}\right]}{\partial x^{2}}-\left[\mathrm{CO}_{2}\right]\left[\mathrm{OH}^{-}\right] k 1_{f}+\left[\mathrm{HCO}_{3}^{-}\right] k 1_{r}-$ $\left[\mathrm{HCO}_{3}^{-}\right]\left[\mathrm{OH}^{-}\right] k 2_{f}-\left[\mathrm{CO}_{3}^{2-}\right] k 2_{r}$

Where the boundary conditions can be written as $(t>0)$

$$
D_{\mathrm{CO}_{2}} \frac{\partial^{2}\left[\mathrm{CO}_{2}\right]}{\partial x^{2}}=\mathrm{CO}_{2}^{\text {consumption }}, \quad \mathrm{D}_{\mathrm{HCO}_{3}^{-}} \frac{\partial^{2}\left[\mathrm{HCO}_{3}^{-}\right]}{\partial x^{2}}=0
$$




$$
D_{\mathrm{CO}_{3}^{2-}} \frac{\partial^{2}\left[\mathrm{CO}_{3}^{2-}\right]}{\partial x^{2}}=0, \quad D_{\mathrm{OH}^{-}} \frac{\partial^{2}\left[\mathrm{OH}^{-}\right]}{\partial x^{2}}=O H_{\text {consumption }}^{-}
$$

The boundary conditions are based on the assumption that bicarbonate and carbonate ions are always in equilibrium and the initial values are corresponding bulk concentrations. The concentration of $\mathrm{CO}_{2}$ at 9 atm is calculated by using the Henry's Constant $\left(0.0342 \mathrm{~mol} \mathrm{~L}^{-1} \mathrm{~atm}^{-1}\right)$. The effect of the pressure on the equilibrium constants of the reactions is assumed to be negligible. A diffusion layer thickness of 100 $\mu \mathrm{m}$ is used for all the calculations. It is important to note that the product distribution has a relatively minor effect on local $\mathrm{pH}$ compared to current density and electrolyte concentration.

\subsection{References}

1. Wonders, A., et al., On-line mass spectrometry system for measurements at singlecrystal electrodes in hanging meniscus configuration. Journal of applied electrochemistry, 2006. 36(11): p. 1215-1221.

2. Golden, T.D., et al., Electrochemical Deposition of Copper(I) Oxide Films. Chemistry of Materials, 1996. 8(10): p. 2499-2504.

3. Gupta, N., M. Gattrell, and B. MacDougall, Calculation for the cathode surface concentrations in the electrochemical reduction of $\mathrm{CO}_{2}$ in $\mathrm{KHCO}_{3}$ solutions. Journal of applied electrochemistry, 2006. 36(2): p. 161-172. 



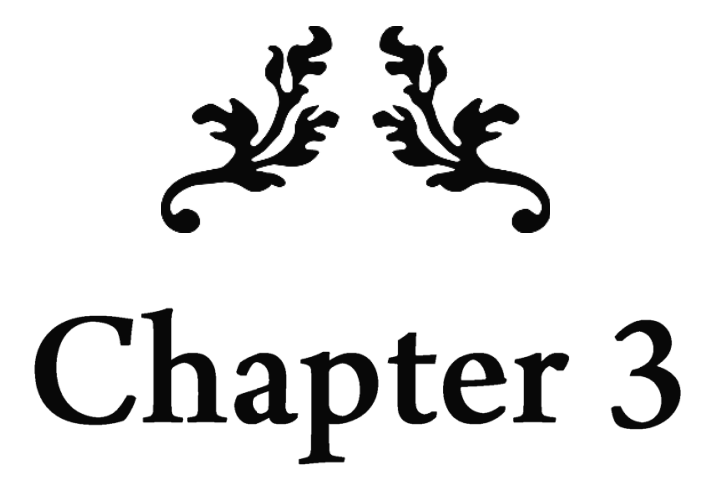

Controlling the catalytic selectivity of copper nanoparticles during $\mathrm{CO}_{2}$ electroreduction

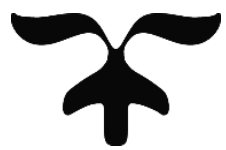




\begin{abstract}
The catalytic activity and hydrocarbon selectivity in electrochemical carbon dioxide $\left(\mathrm{CO}_{2}\right)$ reduction on copper nanoparticles is discussed. Cuprous oxide films with [100], [110] and [111] orientation and variable thickness were electrodeposited by reduction of copper (II) lactate on commercially available copper plates. After initiation of the electrochemical $\mathrm{CO}_{2}$ reduction by these oxide structures, the selectivity of the process was found to largely depend on the parent $\mathrm{Cu}_{2} \mathrm{O}$ film thickness, rather than on the initial crystal orientation. Starting with thin $\mathrm{Cu}_{2} \mathrm{O}$ films, besides $\mathrm{CO}$ and hydrogen, selective formation of ethylene is observed with very high ethylene-to-methane ratios ( $\approx 8$ to 12$)$. In addition to these products, thicker $\mathrm{Cu}_{2} \mathrm{O}$ films yield a remarkably large amount of ethane. Long term Faradaic efficiency analysis of hydrocarbons shows no sign of deactivation of the electrodes after 5 hours of continuous experiment. Online mass spectroscopy studies combined with $\mathrm{X}$-ray diffraction data suggest reduction of the $\mathrm{Cu}_{2} \mathrm{O}$ films in the presence of $\mathrm{CO}_{2}$ occurs, generating a nanoparticulate $\mathrm{Cu}$ morphology, prior to the production of hydrogen, $\mathrm{CO}$, and hydrocarbons. Optimizing coverage, number density and size of the copper nanoparticles, as well as local surface $\mathrm{pH}$, may allow highly selective formation of the industrially important product ethylene.
\end{abstract}




\subsection{Introduction}

Carbon dioxide $\left(\mathrm{CO}_{2}\right)$ is the thermodynamically stable product of most hydrocarbon feedstock combustion processes and a significant contributor to the greenhouse effect.[1] The accumulation of $\mathrm{CO}_{2}$ in the atmosphere has an impact on climate change and could threaten the environment and eventually the worldwide economy. [2,3] The conversion of $\mathrm{CO}_{2}$ into useful products and chemicals is thus a very attractive research area. $[4,5]$ A currently proposed approach is the electrocatalytic reduction of $\mathrm{CO}_{2}$ where the electrons are supplied from renewable energy sources, such as photovoltaics, wind and blue energy. [6-8] However, $\mathrm{CO}_{2}$ reduction into fuels is anticipated to be very challenging, due to the necessary multiple number of proton-coupled electron transfer steps.[9]

Many polycrystalline metals have been analyzed for their activity towards electrocatalytic $\mathrm{CO}_{2}$ reduction.[10] Among the metal electrodes, copper is the most extensively studied since it is the only metal capable of producing hydrocarbons from $\mathrm{CO}_{2}$ with reasonable Faradaic efficiencies $(\mathrm{FE})$ in aqueous solutions at ambient conditions of temperature and pressure.[11, 12] However, high overpotentials required for the activation of $\mathrm{CO}_{2}$ and rapid degradation of the catalytic activity are the major obstacles for commercializing the process. [13, 14] Even though the deactivation of the catalytic activity is reported to be suppressed by preparing electrolytes via preelectrolysis or applying anodic pulses, $[14,15]$ the reproducibility and compatibility of these preparation steps are not appropriate for large scale application. The key issue in the current state of electrocatalytic $\mathrm{CO}_{2}$ reduction is to find a stable and robust cathode material that could selectively convert $\mathrm{CO}_{2}$ and $\mathrm{H}_{2} \mathrm{O}$ to useful products at low overpotentials.[16] Energy efficient processes at low overpotentials were reported using ionic liquids as solvent [17] or pyridine as additive[18]. Besides low current densities reported in these studies, the effects of the solvents on the electrolyzer are unknown. The modification of polycrystalline copper surfaces with different structures might allow for a stable electrode performance in aqueous solutions and energy efficient transformation routes towards energy dense products. [19]

Growing oxide films on top of a metallic surface is a widely used method of producing structured electrode surfaces. [20,21] Methanol was anticipated to form on cuprous oxide $\left(\mathrm{Cu}_{2} \mathrm{O}\right)$ coated $\mathrm{Cu}$ surfaces.[22, 23] However, deactivation of these electrodes for methanol production after short reaction times suggests conversion of the oxide films in the process. Recently, thermally produced thick oxide films were reported to decrease the overpotential of product formation without losing activity for extended electrolysis time.[19, 24-26] The $\mathrm{CO}_{2}$ electrocatalytic reduction process on 
these copper oxide films was proposed to take place on in-situ produced copper nanoparticles during cathodic reconstruction of the $\mathrm{Cu}_{2} \mathrm{O}$ oxide films. The selectivity of the thick films was predominantly towards carbon monoxide ( $\mathrm{CO}$ ) and formic acid at low potentials, contrary to thin oxide films which mainly produced methanol.[19] Although several aspects of the thermal-oxide derived electrodes have been validated by Kanan and coworkers, the selectivity towards hydrocarbons, and mechanistic pathways explaining formation thereof, have not been extensively described.

In this study, the performance of electrochemically produced $\mathrm{Cu}_{2} \mathrm{O}$ coated copper substrates towards $\mathrm{CO}_{2}$ reduction was evaluated in terms of selectivity, activity and long term stability. $\mathrm{Cu}_{2} \mathrm{O}$ films with surfaces exposing different crystal facets were prepared via controllable, facile, well established electrochemical methods, and the resulting catalytic performance was evaluated using gas chromatography and online electrochemical mass spectroscopy (OLEMS). The effects of the crystal orientation, oxidation state and thickness of the films on the resulting $\mathrm{CO}_{2}$ electrocatalytic reduction product selectivity will be extensively discussed, with focus on the formation of methane, ethylene and ethane.

\subsection{Results and Discussion}

\subsubsection{Electrodeposition of $\mathrm{Cu}_{2} \mathrm{O}$ Films.}

SEM images and the corresponding XRD patterns of as prepared $\mathrm{Cu}_{2} \mathrm{O}$ films are shown in Figures 1a-d. The XRD patterns acquired clearly indicate that the crystals obtained are preferentially oriented in either [100], [110] or [111] directions, depending on the applied synthesis conditions. The films grown at $\mathrm{pH} 12$ with a current density of $0.8 \mathrm{~mA} / \mathrm{cm}^{2}$ exhibit triangular pyramids oriented in the [110] direction where the (100) and (010) facets are exposed.[27] Increasing the current density to $2 \mathrm{~mA} / \mathrm{cm}^{2}$ at $\mathrm{pH} 12$ favors the growth in [100] directions with three-faced pyramids, where the sides of the pyramids expose (111) facets.[28] At $\mathrm{pH} 9$ the morphology of the crystals evolved to four sided pyramids oriented in the [100] direction exposing (111) facets.[29]

Electrodeposition of $\mathrm{Cu}_{2} \mathrm{O}$ films has been extensively studied and well established from $\mathrm{Cu}^{2+}$ solutions in the presence of the surfactants and complexing agents, such as sodium dodecyl sulfate, or lactic acid.[30-32] Formation of [111] and [100] oriented films was studied previously extensively,[28, 33-35] whereas [110] oriented films were reported in a couple of studies and were found to be stable in a very narrow $\mathrm{pH}$ range.[27] Our attempts to reproduce [110] oriented films were successful, 
a)

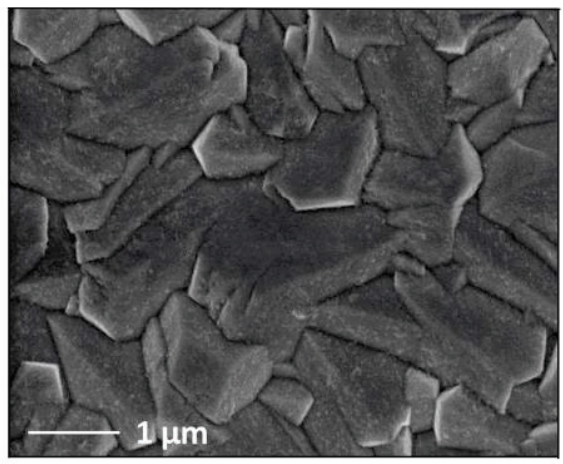

c)

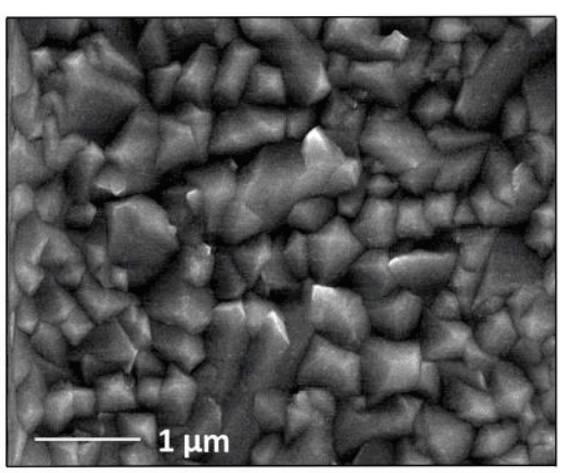

b)

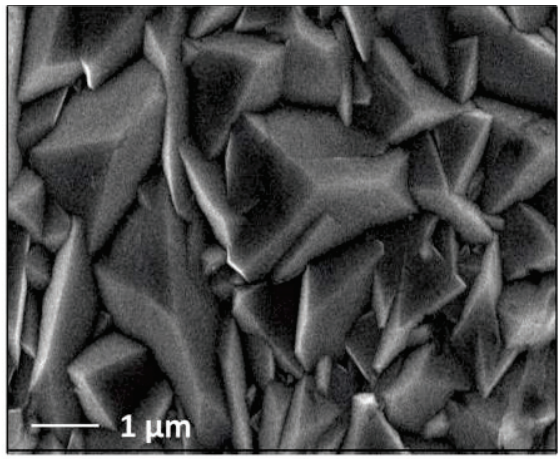

d)

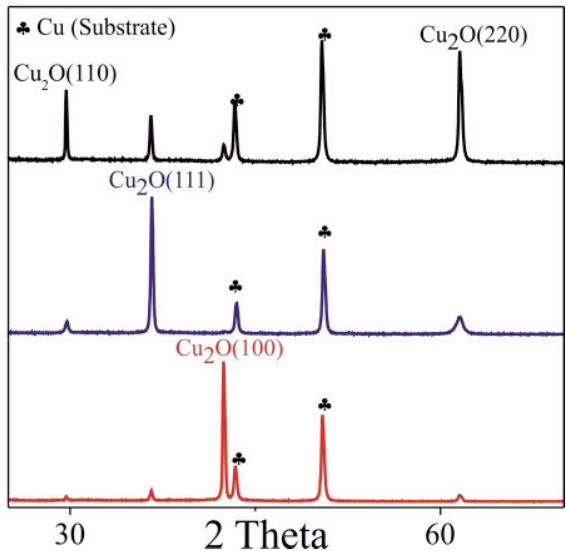

Figure 1: SEM images of as deposited $\mathrm{Cu}_{2} \mathrm{O}$ films with predominant a) [110], b) [111] and c) $[100]$ orientations. d) $\mathrm{X}$-ray diffraction patterns of $\mathrm{Cu}_{2} \mathrm{O}$ films electrochemically deposited on copper substrates.

but the orientation of the films was found to be different at increasing thickness, which is most likely due to a change in $\mathrm{pH}$ and copper concentration during the electrodeposition.[28] Nevertheless, we found that increasing the amount of lactic acid at $\mathrm{pH} 12$ yields [110] oriented films with low current densities in a reproducible way.

\subsubsection{Electrochemical $\mathrm{CO}_{2}$ reduction in $0.1 \mathrm{M} \mathrm{KHCO}_{3}$ on different facets of $\mathrm{Cu}_{2} \mathrm{O}$ films.}

The distribution of the gaseous products obtained during the $\mathrm{CO}_{2}$ electrochemical reduction at a cathodic potential of $-1.1 \mathrm{~V}$ vs RHE is presented in Figure 2a. It can be seen that only minor differences exist in the FE of the gaseous products between the different predominant crystal oriented films. In particular, $\mathrm{CO}$, methane, ethylene and some ethane were gaseous products observed of $\mathrm{CO}_{2}$ 
electrochemical reduction. $\mathrm{CO}$ desorbs from the surface and is a well-known intermediate for the formation of ethylene and methane.[10] Ethylene was the major product among the hydrocarbons for all of the samples with a small variation in ethylene/methane ratio observed. Ethane formation was detected with low FE for all of the samples investigated. Unfortunately, we were not able to compare the data to the performance of polycrystalline copper electrodes: complete deactivation of polycrystalline copper was observed, before steady state was reached.

XRD patterns obtained of the samples after the $\mathrm{CO}_{2}$ experiments were acquired and show that only diffraction lines due to metallic copper are present (not shown here). Thus, in the potential range applied here for $\mathrm{CO}_{2}$ electrochemical reduction $(-0.2 \mathrm{~V}$ to $-1.1 \mathrm{~V}$ vs $\mathrm{RHE})$, none of the $\mathrm{Cu}_{2} \mathrm{O}$ films were stable, and reduced to metallic copper. The SEM images of the samples shown in Figure $2 \mathrm{~b}-\mathrm{d}$ signify

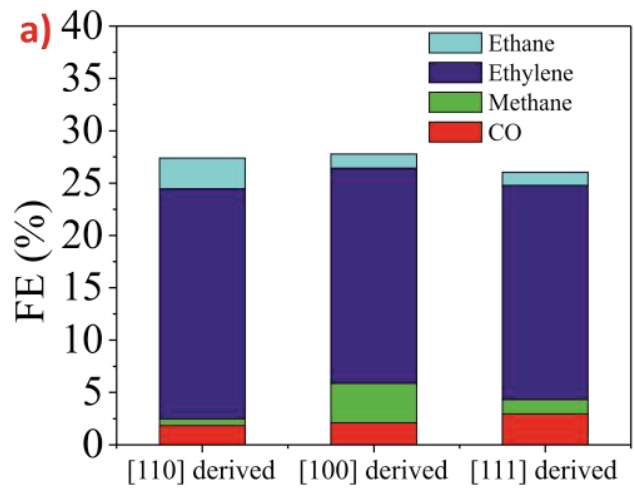

b)

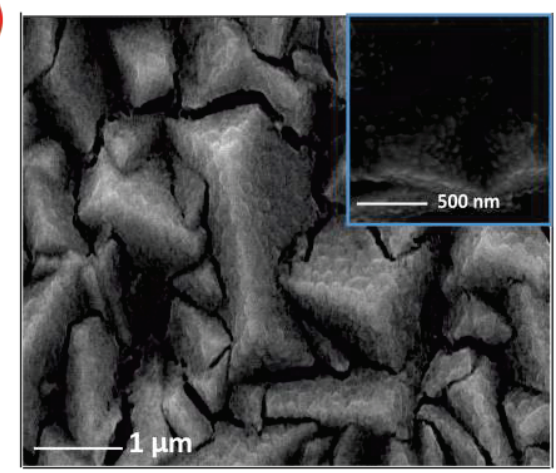

c)
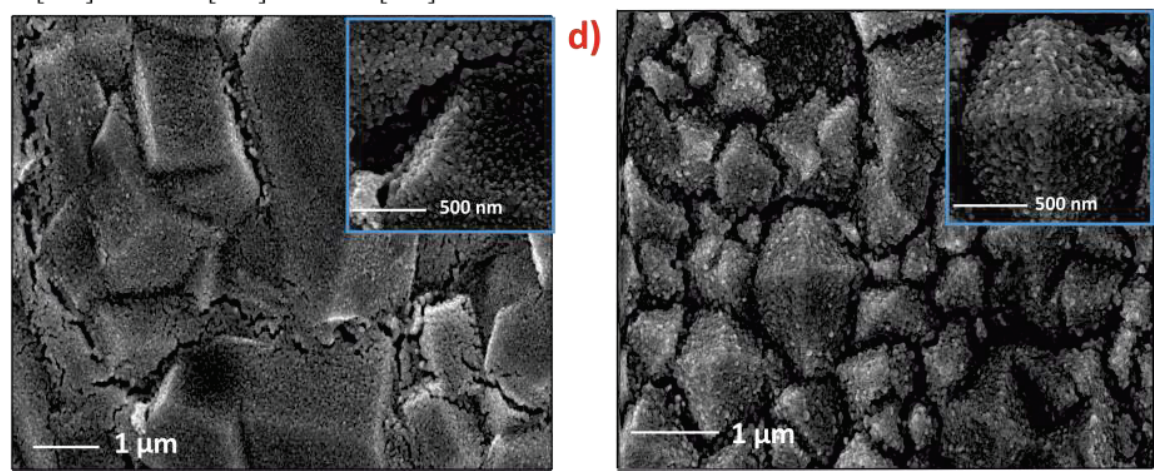

Figure 2. a) FE of gaseous products from $\mathrm{CO}_{2}$ reduction at $-1.1 \mathrm{~V}$ vs RHE in $0.1 \mathrm{M} \mathrm{KHCO}_{3}$ solution for oxides having different crystal orientation. SEM images of copper nanoparticles obtained after reduction of oxides in the b) [110], c) [111] and d) [100] orientations. Corresponding SEM images are also shown with high resolution images in the inset. 
different microscopic morphology of the films obtained after the reduction process, when compared to that before the reduction. When compared to those in Figure 1, the smooth surfaces of the pyramids roughened and the films cracked at the intersection of the pyramids. The higher magnification insets in Figure 2 show that pyramids are now composed of spherical nanometer sized copper domains. As it will be established further using OLEMS studies, $\mathrm{CO}_{2}$ reduction apparently did not proceed on $\mathrm{Cu}_{2} \mathrm{O}$, but rather on in situformed metallic copper nanoparticles. Even though there is no distinct difference between the samples in terms of their corresponding product selectivity as a function of initial $\mathrm{Cu}_{2} \mathrm{O}$ orientation, suggesting the structure of the in situ formed copper nanoparticles is not much different, the observed high ethylene selectivity of the electro-catalytically active copper surfaces is distinctly different from the selectivities previously reported for polycrystalline copper, and oxide derived copper nanoparticles.[12, 19, 26] Electro-polished polycrystalline copper is well known to produce methane as the major product within the investigated potential range,[13] while ethane was reported to be a dominant product on copper derived from thermally formed oxide films.[19] Further, in agreement with our product distribution, anodically created oxide films were found to lead to formation of predominantly ethylene, but for these films ethane formation was not observed.[26] To further analyze the effect of the structure of the oxide derived copper nanoparticle layer on hydrocarbon selectivity, layers with different thickness were prepared and evaluated in electrocatalytic $\mathrm{CO}_{2}$ reduction. 


\subsubsection{Electrochemical $\mathrm{CO}_{2}$ reduction in $0.1 \mathrm{M} \mathrm{KHCO}_{3}$ on $(110) \mathrm{Cu}_{2} \mathrm{O}$ films of increasing thickness.}

The XRD patterns of a series of [110] oriented $\mathrm{Cu}_{2} \mathrm{O}$ films prepared by passing a different amount of total electrical charge through the electrochemical cell, are shown in Figure 3a. It can be seen that the diffraction line due to the [110] plane becomes more predominant as the thickness of the films increases. Likewise, the intensity of the metallic copper diffraction lines from the substrate decreases, as the thickness of $\mathrm{Cu}_{2} \mathrm{O}$ films increases. Growth in the [100] and [111] directions has been reported to be restricted to a localized or spotty deposition, suggesting growth of our films is more homogeneous to explain the observed preferred [110] crystal orientation of our films. [34] $\mathrm{CO}_{2}$ reduction on the thus prepared electrodes was performed in the

a)
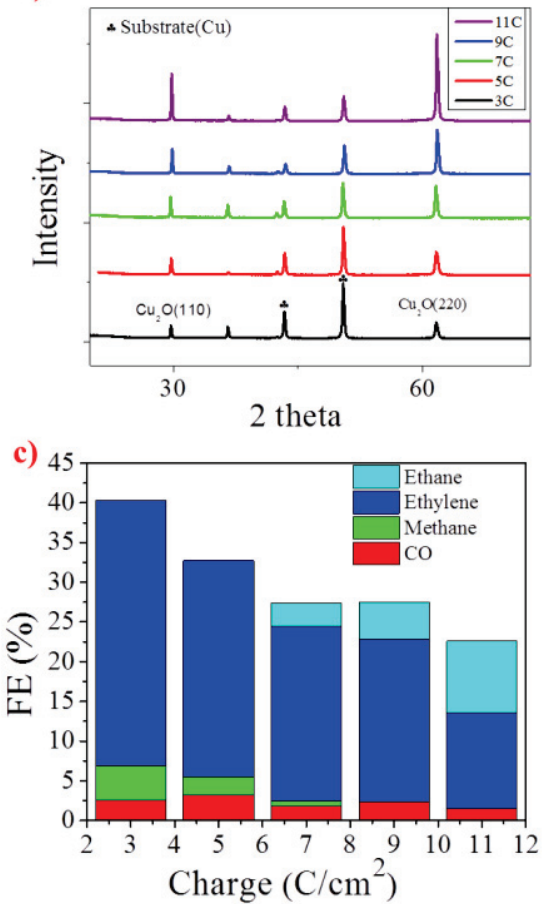

b)
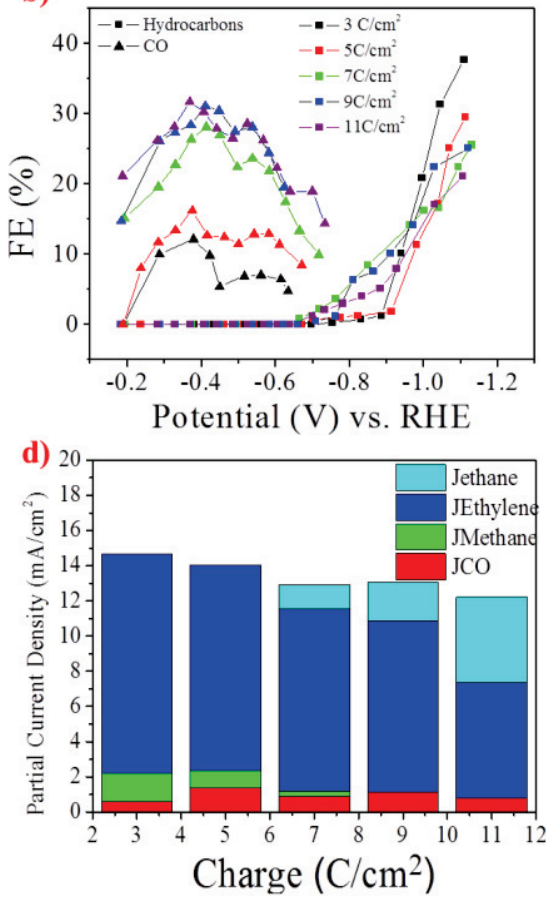

Figure 3: a) The X-ray diffraction patterns of the [110] oriented $\mathrm{Cu}_{2} \mathrm{O}$ films prepared by changing the total charge passed through the cell. b) FEs of $\mathrm{CO}$ and hydrocarbons at different potentials as a function of initial thickness of the films c) FE and d) partial geometric current density of gaseous products from $\mathrm{CO}_{2}$ reduction at $-1.1 \mathrm{~V}$ vs $\mathrm{RHE}$ in $0.1 \mathrm{M} \mathrm{KHCO}_{3}$ solution as a function of initial thickness of the films (FEs of $\mathrm{CO}$ are given in a limited potential range for clarity). 
potential range between -0.2 and $-1.1 \mathrm{~V}$ vs RHE. A plot of CO and hydrocarbon FE (\%) vs. the applied cathodic potential is shown in Figure $3 \mathrm{~b}$. For the samples having higher initial oxide thicknesses, CO formation starts at very low overpotentials $(\sim-0.1 \mathrm{~V})$ and reaches a maximum between -0.3 and $-0.5 \mathrm{~V}$ vs RHE. These observations are consistent with findings on thermally induced oxide derived films of copper.[19] At higher applied potentials, the FE towards $\mathrm{CO}$ decreases, and hydrocarbon products start to evolve with onset potentials between -0.65 and $-0.75 \mathrm{~V}$ vs RHE. The change in hydrocarbon product distribution (FE (\%)) at cathodic potential of $-1.1 \mathrm{~V}$ vs RHE as a function of thickness is given at Figure $3 \mathrm{c}$. A major observation is that the distribution of the hydrocarbon products changes distinctively from methane to ethane, $\mathrm{CO}$ being relatively constant, and ethylene continuously decreasing. Further, the FE of the hydrocarbon products clearly decreases for increasing layer thickness, and hence the decrease in partial current density values (Figure $3 \mathrm{~d}$ ). In other words, the production rate of hydrocarbons (and $\mathrm{CO}_{2}$ conversion rate) only slightly decreases. No deactivation towards the hydrocarbon production was observed for the thinnest samples over the course of 5 hours, as compared to polycrystalline copper which was found to rapidly deactivate within 40 minutes.[14]

SEM images of the thinnest $\left(3 \mathrm{C} / \mathrm{cm}^{2}\right)$ and the thickest $\left(11 \mathrm{C} / \mathrm{cm}^{2}\right) \mathrm{Cu}_{2} \mathrm{O}$ samples after the electrochemical $\mathrm{CO}_{2}$ reduction process are shown in Figures $4 \mathrm{a}$ and $\mathrm{b}$, respectively. The morphology of the thinnest [110] oriented films is not well pronounced, whereas thicker films show characteristic triangular pyramid morphology. It can be seen that the increase in the initial oxide films thickness increases the coverage of the pyramids, which are again composed of the aggregated copper

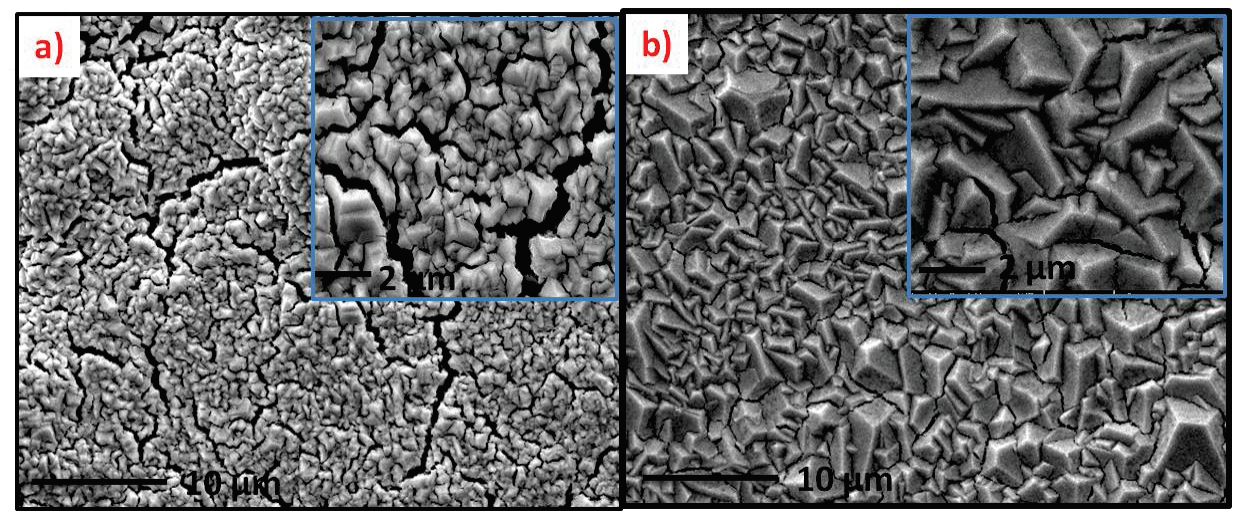

Figure 4: SEM image of the [110] oriented a) thinnest $\left(3 \mathrm{C} / \mathrm{cm}^{2}\right)$ and the b) thickest $\left(11 \mathrm{c} / \mathrm{cm}^{2}\right)$ $\mathrm{Cu}_{2} \mathrm{O}$ samples after the electrochemical reduction. 
nanoparticles after reduction. As the thickness of the initial oxide films increases, the size of the cracks between the overlapping pyramids decreases and the individual pyramids start to form continuous films.

Sample surface roughness, relative to that of bare copper, was measured by using double layer capacitance of the surfaces (Figure 5a and 5b). Charging of the double layer creates a certain current, due to the migration of charges. This current can be described with the equation below;

$$
I_{c}=\frac{d Q_{m}}{d t}=C_{d}(E) \frac{d E}{d t}
$$
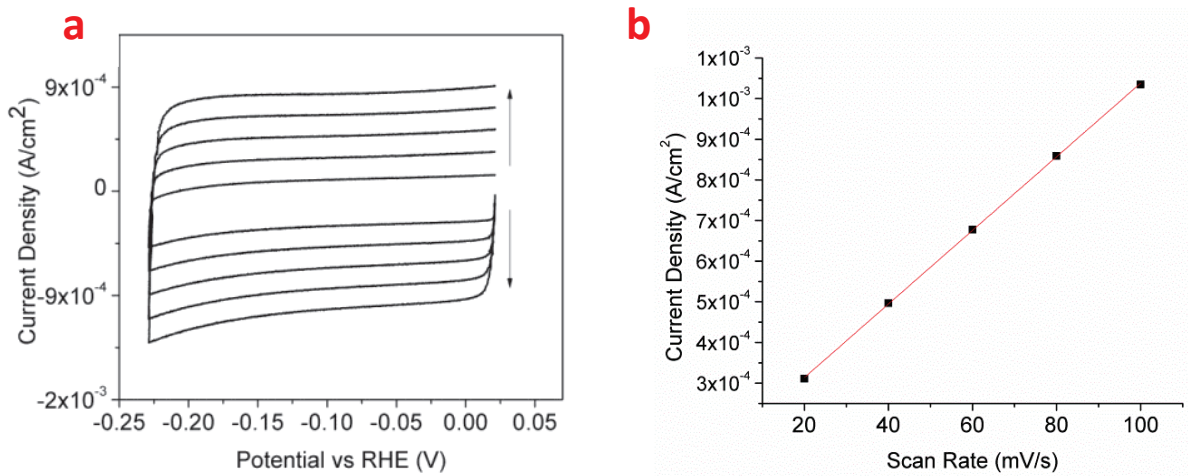

Figure 5: a) CV curves of a nano-particulate $\mathrm{Cu}$ surface derived from an oxide film prepared at $11 \mathrm{C} / \mathrm{cm}^{2}$. The arrows indicate the trends induced by an increase in scan rate. b) the current density vs. scan rate plot for the corresponding film.

\begin{tabular}{ccc}
\hline $\begin{array}{c}\text { Charge passed } \\
\text { through }\end{array}$ & Capacitance & $\begin{array}{c}\text { Surface } \\
\text { Roughness Factor }\end{array}$ \\
\hline Bare Copper & $0.14 \mathrm{mF}$ & 1 \\
$3 \mathrm{C} / \mathrm{cm}^{2}$ & $1.6 \mathrm{mF}$ & 11 \\
$5 \mathrm{C} / \mathrm{cm}^{2}$ & $2.4 \mathrm{mF}$ & 17 \\
$7 \mathrm{C} / \mathrm{cm}^{2}$ & $5.1 \mathrm{mF}$ & 36 \\
$9 \mathrm{C}^{2} \mathrm{~cm}^{2}$ & $6.1 \mathrm{mF}$ & 44 \\
\hline $11 \mathrm{C} / \mathrm{cm}^{2}$ & $9.1 \mathrm{mF}$ & 65 \\
\hline
\end{tabular}

Table 1: The capacitance values and surface roughness factors of the films as a function of initial thickness of the films. 
Where $I_{c}$ is the current, $Q_{m}$ the migrated charge, $E$ the potential, $t$ the time and $C_{d}$ is the double layer capacity. The charges associated with movement of electrolyte ions, the current flow, at low potentials can be measured by cyclic voltammetry. When plotting the current against the scan rate $(\mathrm{dE} / \mathrm{dt})$, the double layer capacitance can be obtained. This double layer capacitance can now be used to calculate the relative roughness of the electrode compared to smooth electrodes. We measured double layer capacitance of the surfaces in $0.5 \mathrm{M} \mathrm{H}_{2} \mathrm{SO}_{4}$ solutions. Sample surface roughness, relative to that of bare copper, is tabulated in Table 1. As the oxide layer thickness increases, the roughness factors of the in situ formed nano-particulate copper surface increase as well, ranging from 11 for an oxide derived layer produced at $3 \mathrm{C} / \mathrm{cm}^{2}$ to 65 for an oxide derived layer produced at $3 \mathrm{C} / \mathrm{cm}^{2}$. Therefore, the initial oxide layer can be viewed alternatively as catalyst loading which is commonly used in supported heterogeneous catalysts.

Extensive research on the relation between the structure of Copper surfaces and the product composition exists. Single crystal copper electrodes by Hori et al. showed that stepped surfaces result in higher selectivity towards ethylene.[36] Introducing (111) steps on to the (100) basal plane increases the formation of ethylene over methane with the highest ethylene/methane ratio of $\sim 14$ observed on $\mathrm{Cu}(711)$.[37] On the other hand, the width of the $\mathrm{Cu}(100)$ terraces is suggested to be a decisive factor towards ethylene formation on stepped copper surfaces.[38] Recently Schouten et al. proposed that ethylene formation takes place at low overpotentials on $\mathrm{Cu}(100)$ through adsorption of $\mathrm{CO}$ dimers, whereas at higher potentials both ethylene and methane formation takes place on (100) and (111) facets via a shared intermediate.[39] Although we appreciate the effect of surface exposed planes on selectivity, we conclude on the basis of the very similar results obtained for the different $\mathrm{Cu}_{2} \mathrm{O}$ morphologies that the structure of the $\mathrm{Cu}$ nanoparticles in situ formed in electrochemical $\mathrm{CO}_{2}$ reduction are not profoundly different. To explain the dramatic changes in selectivity due to increasing layer thickness thus has to have an alternative origin.

More importantly, the $\mathrm{CO}$ dimerization mechanism on $\mathrm{Cu}(100)$ is enhanced in alkaline media.[40] Therefore, ethylene formation is suggested to take place at conditions of high (local) pH.[38] The trend of product selectivity towards hydrocarbons observed here with increasing oxide layer thickness is then explained by local changes in $\mathrm{pH}$ during the electrolysis. Gupta et al. modeled the local $\mathrm{pH}$ changes during the electrochemical $\mathrm{CO}_{2}$ reduction in $\mathrm{KHCO}_{3}$ solutions. [41] The local $\mathrm{pH}$ near the electrode surface during electrolysis is higher than the bulk value and depends on 
the applied current density, electrolyte concentration, and stirring speed. The increase in surface roughness and the geometrical current density of the $\mathrm{Cu}$ films investigated here, likely lead to an increase in local $\mathrm{pH}$ due to the increase in overall consumption of $\mathrm{H}^{+}$. The increasing geometrical current density as a function of film thickness (not shown here) is in agreement with the presence of the higher surface area, providing additional surface sites for the reaction. The formation of methane and ethylene have been reported to have a distinctly different $\mathrm{pH}$ dependence due to the difference in the involvement of protons in their rate limiting step.[38, 42] As a result, at higher (local) $\mathrm{pH}$, the formation of ethylene from the $\mathrm{CO}$ intermediate is preferred over the formation of methane. The increase in the geometrical current density and local $\mathrm{pH}$ changes could therefore possibly explain the decrease and disappearance of methane with the increasing catalyst loading (see Chapter 4).

Ethane formation so far has only been observed on very rough surfaces, such as electrodeposited foam-like structures,[43] as well as thermally produced oxide films reduced by hydrogenation or electrochemically.[19, 42] Recent calculations on C-C coupling on $\mathrm{Cu}(211)$ surfaces suggest the kinetic barriers for the coupling are strongly influenced by the degree of the adsorbed CO hydrogenation.[44] These kinetic barriers tend to decrease with increasing degree of the surface bound $\mathrm{CO}$ hydrogenation, which can favor ethane. However, the absence of methane formation on the electrodes where ethane is formed suggest the formation is unlikely to occur via the formation of adsorbed $-\mathrm{CH}_{3}$, which is proposed as an intermediate for methane formation.[45] The hydrogenation appears to take place after the C-C coupling, such as further reduction of ethylene, in agreement with ethane being formed at the expense of ethylene (see Chapter 5).

In order to obtain deeper insight into the role of the cuprous oxide on $\mathrm{CO}_{2}$ electrochemical reduction, OLEMS studies were conducted on the [111] and [100] oriented films of different thickness. All of the samples prepared by passing 1 to 5 $\mathrm{C} / \mathrm{cm}^{2}$ showed similar catalytic behavior, when analyzed with OLEMS. Therefore, only the $5 \mathrm{C} / \mathrm{cm}^{2}$ sample is discussed in detail. The $\mathrm{CV}$ graphs obtained are shown in Figure 6, together with the corresponding mass spectroscopy data. Specifically, the very first cathodic sweep is shown in Figure 6a, whereas the following, second sweep, is shown in Figure 6b. A clear reductive wave can be observed in Figure 6a, which is absent in Figure 6b. This is due to the decomposition of electrodeposited cuprous oxide, which starts around $-0.3 \mathrm{~V}$ vs RHE. Since this process always proceeds during the initial cathodic sweep, all electrochemical $\mathrm{CO}_{2}$ reduction proceeds on the newly in situ formed metallic copper particles and not on as-deposited $\mathrm{Cu}_{2} \mathrm{O}$, in agreement with 
a)

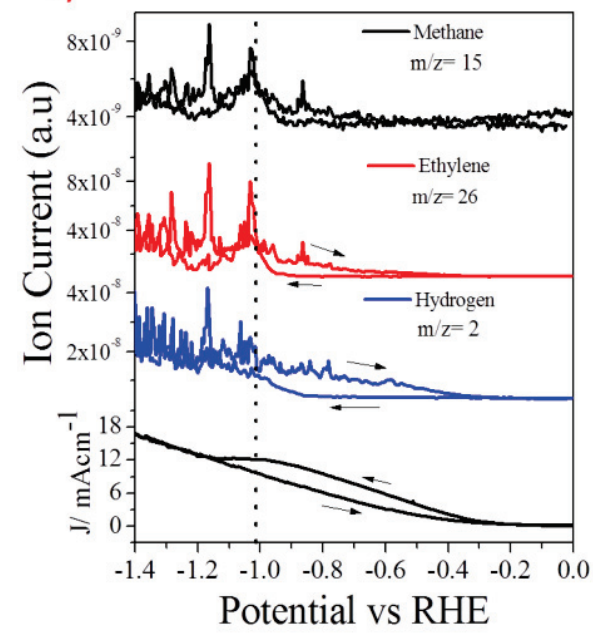

b)

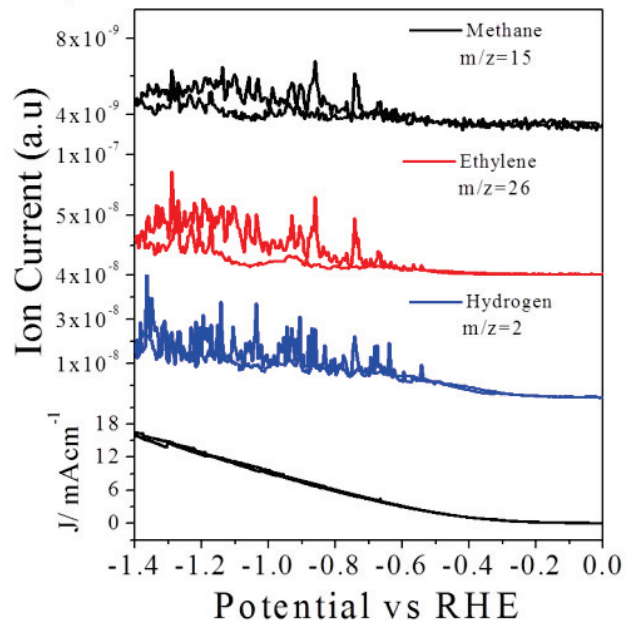

Figure 6: Ion currents for methane, ethylene, and hydrogen probed by OLEMS as a function of applied potential. Cyclic voltammetry curve of oxide films on copper in $\mathrm{CO}_{2}$ saturated 0.1 $\mathrm{M} \mathrm{KHCO}_{3}$ solution a) first scan b) second scan (scan rate $1 \mathrm{mV} \mathrm{s}^{-1}$ ). Arrows indicate the forward and backward scans for clarity.

our data presented earlier. The dashed vertical line in Figure 6a corresponds to the potential where a total charge of $5 \mathrm{C} / \mathrm{cm}^{2}$ was passed through the electrode for the reduction of the films. Importantly, in the first and the consecutive forward scans no mass fragments corresponding to hydrogen and ethylene were detected, until reaching the conditions needed for the reduction of the films. At the same potentials, appreciable amount of hydrogen and ethylene is produced during the reverse scan, as well as the second and the following sweep cycles.

Copper oxides are known to form spontaneously on copper when exposed to air or electrolyte solution. [46] Intentionally formed $\mathrm{Cu}_{2} \mathrm{O}$ films on copper have been reported to yield methanol with very high FE.[23, 47] However, the catalytic activity of these degrades quickly, which is attributed to the decomposition of cuprous oxide to copper, and methanol is considered to be only formed during the reduction of these oxide films. Further, the final composition of the copper oxide electrocatalyst surface and its transformations during the reduction process are not exactly known. Spectroscopic analysis of spent $\mathrm{CO}_{2}$ electroreduction electrodes indicate the presence of $\mathrm{Cu}(\mathrm{I})$ and $\mathrm{Cu}(\mathrm{II})$ oxides after the reaction,[47] but in situ analysis is required to verify the existence of the oxide films during the electrocatalytic process. Using OLEMS, no noteworthy amount of methanol was detected from the samples evaluated 
here. This once again suggests that gaseous $\mathrm{CO}_{2}$ electrocatalytic reduction products is governed by the copper metal formed from the $\mathrm{Cu}_{2} \mathrm{O}$ films during in situ transformations.

This research highlights the selectivity in electrocatalytic $\mathrm{CO}_{2}$ reduction of copper nanoparticles derived from different $\mathrm{Cu}_{2} \mathrm{O}$ morphologies and thicknesses. The orientation of electrodeposited $\mathrm{Cu}_{2} \mathrm{O}([110],[111]$ and $[100])$ has only a minor effect on the product selectivity. The initial oxide thickness, however, strongly influences the selectivity of the electrocatalytic process. Specifically, OLEMS studies show that the $\mathrm{Cu}_{2} \mathrm{O}$ reduction itself seems to be highly favored, when compared to $\mathrm{CO}_{2}$ reduction or water splitting, since no products were detected by online mass spectroscopy on as deposited $\mathrm{Cu}_{2} \mathrm{O}$. Further, the catalytic behavior is predominantly determined by roughness associated local $\mathrm{pH}$ changes, impacting the hydrocarbon selectivities. The optimum number density of nanoparticles with the combination of the right electrolyte $(\mathrm{pH}) \mathrm{can}$ open up routes for highly selective ethylene formation via electrochemical reduction of $\mathrm{CO}_{2}$ in reactors where mass transport is improved i.e. using gas diffusion electrodes.

\subsection{References}

1. D'Alessandro, D.M., B. Smit, and J.R. Long, Carbon Dioxide Capture: Prospects for New Materials. Angewandte Chemie International Edition, 2010. 49(35): p. 6058-6082.

2. Solomon, S., et al., Cambridge University Press: Cambridge. UK and New York, NY, USA, 2007.

3. Halmann, M.M. and M. Steinberg, Greenhouse gas carbon dioxide mitigation: science and technology1999: CRC press.

4. Ritter, S.K., What can we do with carbon dioxide. Chemical and Engineering News, 2007. 85(18): p. 11-17.

5. Olah, G.A., G.S. Prakash, and A. Goeppert, Anthropogenic chemical carbon cycle for a sustainable future. Journal of the American Chemical Society, 2011. 133(33): p. 12881-12898.

6. Blankenship, R.E., et al., Comparing photosynthetic and photovoltaic efficiencies and recognizing the potential for improvement. Science, 2011. 332(6031): p. 805-9.

7. Graves, C., et al., Sustainable hydrocarbon fuels by recycling $\mathrm{CO}_{2}$ and $\mathrm{H}_{2} \mathrm{O}$ with renewable or nuclear energy. Renewable and Sustainable Energy Reviews, 2011. 15(1): p. 1-23. 
8. Mul, G., et al., Functioning devices for solar to fuel conversion. Chemical Engineering and Processing: Process Intensification, 2012. 51: p. 137-149.

9. Kumar, B., et al., Photochemical and Photoelectrochemical Reduction of $\mathrm{CO}_{2}$. Annual Review of Physical Chemistry, 2012. 63: p. 541-569.

10. Hori, Y., Electrochemical $\mathrm{CO}_{2}$ reduction on metal electrodes, in Modern aspects of electrochemistry2008, Springer. p. 89-189.

11. Shibata, H., J.A. Moulijn, and G. Mul, Enabling electrocatalytic Fischer-Tropsch synthesis from carbon dioxide over copper-based electrodes. Catalysis Letters, 2008. 123(3-4): p. 186-192.

12. Hori, Y., et al., Electroreduction of carbon monoxide to methane and ethylene at a copper electrode in aqueous solutions at ambient temperature and pressure. Journal of the American Chemical Society, 1987. 109(16): p. 5022-5023.

13. Gattrell, M., N. Gupta, and A. Co, A review of the aqueous electrochemical reduction of $\mathrm{CO}_{2}$ to hydrocarbons at copper. Journal of Electroanalytical Chemistry, 2006. 594(1): p. 1-19.

14. Hori, Y., et al., "Deactivation of copper electrode" in electrochemical reduction of $\mathrm{CO}_{2}$. Electrochimica Acta, 2005. 50(27): p. 5354-5369.

15. Shiratsuchi, R., Y. Aikoh, and G. Nogami, Pulsed Electroreduction of $\mathrm{CO}_{2}$ on Copper Electrodes. Journal of the Electrochemical Society, 1993. 140(12): p. 3479-3482.

16. Whipple, D.T. and P.J.A. Kenis, Prospects of $\mathrm{CO}_{2}$ Utilization via Direct Heterogeneous Electrochemical Reduction. Journal of Physical Chemistry Letters, 2010. 1(24): p. 3451-3458.

17. Rosen, B.A., et al., Ionic Liquid-Mediated Selective Conversion of $\mathrm{CO}_{2}$ to $\mathrm{CO}$ at Low Overpotentials. Science, 2011. 334(6056): p. 643-644.

18. Seshadri, G., C. Lin, and A.B. Bocarsly, A new homogeneous electrocatalyst for the reduction of carbon dioxide to methanol at low overpotential. Journal of Electroanalytical Chemistry, 1994. 372(1): p. 145-150.

19. Li, C.W. and M.W. Kanan, $\mathrm{CO}_{2}$ reduction at low overpotential on $\mathrm{Cu}$ electrodes resulting from the reduction of thick $\mathrm{Cu}_{2} \mathrm{O}$ films. Journal of the American Chemical Society, 2012. 134(17): p. 7231-4.

20. Jiang, X., T. Herricks, and Y. Xia, CuO Nanowires Can Be Synthesized by Heating Copper Substrates in Air. Nano Letters, 2002. 2(12): p. 1333-1338.

21. Chen, Y. and M.W. Kanan, Tin oxide dependence of the $\mathrm{CO}_{2}$ reduction efficiency on tin electrodes and enhanced activity for tin/tin oxide thin-film catalysts. Journal of the American Chemical Society, 2012. 134(4): p. 1986-1989.

22. Chang, T.Y., et al., Electrochemical reduction of $\mathrm{CO}_{2}$ by $\mathrm{Cu}_{2} \mathrm{O}$-catalyzed carbon clothes. Materials Letters, 2009. 63(12): p. 1001-1003. 
23. Le, M., et al., Electrochemical reduction of $\mathrm{CO}_{2}$ to $\mathrm{CH}_{3} \mathrm{OH}$ at copper oxide surfaces. Journal of the Electrochemical Society, 2011. 158(5): p. E45-E49.

24. Chen, Y., C.W. Li, and M.W. Kanan, Aqueous $\mathrm{CO}_{2}$ Reduction at Very Low Overpotential on Oxide-Derived Au Nanoparticles. Journal of the American Chemical Society, 2012. 134(49): p. 19969-19972.

25. Qiao, J., et al., Formation of $\mathrm{Cu}$ nanostructured electrode surfaces by an annealing-electroreduction procedure to achieve high-efficiency $\mathrm{CO}_{2}$ electroreduction. Electrochemistry Communications, 2014. 38: p. 8-11.

26. Tang, W., et al., The importance of surface morphology in controlling the selectivity of polycrystalline copper for $\mathrm{CO} 2$ electroreduction. Physical Chemistry Chemical Physics, 2012. 14(1): p. 76-81.

27. Wang, L., et al., Electrodeposited copper oxide films: Effect of bath $\mathrm{pH}$ on grain orientation and orientation-dependent interfacial behavior. Thin Solid Films, 2007. 515(5): p. 3090-3095.

28. Joseph, S. and P.V. Kamath, Electrodeposition of $\mathrm{Cu}_{2} \mathrm{O}$ Coatings on Stainless Steel Substrates. Journal of the Electrochemical Society, 2007. 154(7): p. E102E106.

29. Golden, T.D., et al., Electrochemical deposition of copper (I) oxide films. Chemistry of Materials, 1996. 8(10): p. 2499-2504.

30. Julie K. Barton, A.A.V., Eric W. Bohannan, and Jay A. Switzer, Epitaxial Electrodeposition of Copper(I) Oxide on Single-Crystal Copper. Chemistry of Materials, 2001. 13(3): p. 952-959.

31. Joseph, S. and P.V. Kamath, Electrochemical deposition of $\mathrm{Cu}_{2} \mathrm{O}$ on stainless steel substrates: Promotion and suppression of oriented crystallization. Solid State Sciences, 2008. 10(9): p. 1215-1221.

32. Siegfried, M.J. and K.S. Choi, Electrochemical Crystallization of Cuprous Oxide with Systematic Shape Evolution. Advanced Materials, 2004. 16(19): p. 17431746.

33. Teresa D. Golden, M.G.S., Yanchun Zhou, Rachel A. VanderWerf, Robert A. Van Leeuwen, and Jay A. Switzer, Electrochemical Deposition of Copper(I) Oxide Films. Chemistry of Materials, 1996. 8(10): p. 2499-2504.

34. Rakhshani, A.E. and J. Varghese, Galvanostatic deposition of thin films of cuprous oxide. Solar Energy Materials, 1987. 15(4): p. 237-248.

35. Septina, W., et al., Potentiostatic electrodeposition of cuprous oxide thin films for photovoltaic applications. Electrochimica Acta, 2011. 56(13): p. 4882-4888.

36. Hori, Y., et al., Selective Formation of C2 Compounds from Electrochemical Reduction of $\mathrm{CO}_{2}$ at a Series of Copper Single Crystal Electrodes. The Journal of Physical Chemistry B, 2001. 106(1): p. 15-17. 
37. Hori, Y., et al., Adsorption of $\mathrm{CO}$ accompanied with simultaneous charge transfer on copper single crystal electrodes related with electrochemical reduction of $\mathrm{CO}_{2}$ to hydrocarbons. Surface Science, 1995. 335(0): p. 258-263.

38. Schouten, K.J.P., E. Pérez Gallent, and M.T.M. Koper, Structure Sensitivity of the Electrochemical Reduction of Carbon Monoxide on Copper Single Crystals. ACS Catalysis, 2013. 3(6): p. 1292-1295.

39. Schouten, K.J.P., et al., Two Pathways for the Formation of Ethylene in CO Reduction on Single-Crystal Copper Electrodes. Journal of the American Chemical Society, 2012. 134(24): p. 9864-9867.

40. Calle-Vallejo, F. and M.T.M. Koper, Theoretical Considerations on the Electroreduction of $\mathrm{CO}$ to $\mathrm{C} 2$ Species on $\mathrm{Cu}(100)$ Electrodes. Angewandte Chemie International Edition, 2013. 52(28): p. 7282-7285.

41. Gupta, N., M. Gattrell, and B. MacDougall, Calculation for the cathode surface concentrations in the electrochemical reduction of $\mathrm{CO} 2$ in $\mathrm{KHCO} 3$ solutions. Journal of Applied Electrochemistry, 2006. 36(2): p. 161-172.

42. Hori, Y., et al., Electrochemical Reduction of $\mathrm{CO}$ at a Copper Electrode. The Journal of Physical Chemistry B, 1997. 101(36): p. 7075-7081.

43. Gonçalves, M.R., et al., Electrochemical conversion of $\mathrm{CO}_{2}$ to $\mathrm{C} 2$ hydrocarbons using different ex situ copper electrodeposits. Electrochimica Acta, 2013. 102: p. 388-392.

44. Montoya, J.H., A.A. Peterson, and J.K. Nørskov, Insights into C-C Coupling in $\mathrm{CO}_{2}$ Electroreduction on Copper Electrodes. ChemCatChem, 2013. 5(3): p. 737-742.

45. Schouten, K.J.P., et al., A new mechanism for the selectivity to $C 1$ and $C 2$ species in the electrochemical reduction of carbon dioxide on copper electrodes. Chemical Science, 2011.2(10): p. 1902-1909.

46. Pourbaix, M., Atlas of electrochemical equilibria in aqueous solutions1974: National Association of Corrosion Engineers.

47. Frese, K.W., Electrochemical Reduction of $\mathrm{CO}_{2}$ at Intentionally Oxidized Copper Electrodes. Journal of the Electrochemical Society, 1991. 138(11): p. 3338-3344. 



\section{事啭 \\ Chapter 4}

How ethylene is formed preferentially over methane on copper nanoparticles in carbon dioxide electroreduction

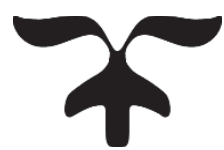




\begin{abstract}
The formation of predominantly ethylene in $\mathrm{CO}_{2}$ electroreduction on rough copper electrodes is often explained by the presence of specific surface crystal steps, edges and defects. We demonstrate that an identical electrode covered with copper nanoparticles can yield either predominantly ethylene or methane, depending on the electrolyte concentration and applied $\mathrm{CO}_{2}$ pressure. Calculations of the $\mathrm{pH}$ near the electrode surface suggest that ethylene formation is favored by a relatively high (local) $\mathrm{pH}$. Furthermore, the conditions leading to the formation of significant amounts of methane, result in rapid deterioration of hydrocarbon production rates, whereas electrode performance in conditions favoring ethylene production can be sustained for hours. This study substantially alters the mechanistic interpretation of abundant formation of ethylene over rough copper surfaces and implies that $\mathrm{pH}$ variations near the electrode surface and applied process conditions need to be taken into consideration.
\end{abstract}




\subsection{Introduction}

The electrochemical $\mathrm{CO}_{2}$ reduction to $\mathrm{CO}$, formic acid, hydrocarbons and alcohols is currently extensively investigated, with the aim of achieving efficient temporary storage of electricity produced by renewable energy sources[1-3]. Many polycrystalline metal electrodes have been analysed in aqueous, organic, and ionic liquid electrolytes for the conversion of $\mathrm{CO}_{2}$ to valuable products.[4, 5] Electroreduction to $\mathrm{CO}$ and formic acid is achieved with high selectivity at low overpotentials in ionic liquids using nanocrystalline metal electrodes, albeit with low current densities. $[6,7]$ Recent theoretical and experimental findings demonstrate that also in aqueous phase electrolytes high $\mathrm{CO}_{2}$ over proton reduction selectivity can be obtained.[8-12]

Copper is a unique electrocatalyst in that hydrocarbons can be produced at ambient pressure with reasonable faradaic efficiency (FE). [13] Although long chain hydrocarbons and a variety of products in minor quantities have been reported, the dominant products are methane and ethylene.[14, 15] Various studies have demonstrated that the product distribution of electrochemical reduction processes over copper electrodes varies remarkably, depending on the preparation of the copper electrode[16-18]. Recently oxide derived metal nanoparticles have received a lot of attention due to a higher energy efficiency, selectivity and stability compared to polycrystalline metal electrodes. $[18,19]$ Generally, copper nanoparticles have been reported to show high faradaic selectivity towards ethylene, as compared to smooth crystalline copper surfaces producing methane.[18] Furthermore, ethane formation was reported by Kanan and coworkers.[19] The selectivity differences observed in various studies discussing copper induced $\mathrm{CO}_{2}$ reduction, are usually correlated to crystal morphology or roughness of the electrodes, the latter associated with an abundance of specific crystal steps or defects.[18-21] Still, completely different selectivities have been observed on similar morphologies with variation in roughness $[16-18,22]$, which suggests that the selectivity might have an alternative origin than solely intrinsic catalytic properties. To validate this hypothesis, we studied the effects of electrolyte concentration and $\mathrm{CO}_{2}$ pressure on the selectivity of methane and ethylene on identical copper nanoparticles in a continuous, pressurized reactor. The selectivity differences experimentally observed are discussed on the basis of the calculated local $\mathrm{pH}$ near the electrode surface, and recent (theoretical) findings described in the literature. 


\subsection{Results and Discussion}

Copper nanoparticles on copper substrates were prepared by electrodeposition of cuprous oxide $\left(\mathrm{Cu}_{2} \mathrm{O}\right)$ from copper lactate solutions and subsequent reduction in $0.1 \mathrm{M} \mathrm{KHCO}_{3}$ (See Chapter 2 for details). SEM images of a typical electrode covered with aggregated copper nanoparticles are given in Figure 1. The performance of these electrodes was tested at an applied potential of $-1.8 \mathrm{~V}$ vs $\mathrm{Ag} / \mathrm{AgCl}$ in a pressurized autoclave under a continuous flow of $\mathrm{CO}_{2}$, while the gas phase products were analyzed by Gas Chromatography (GC). The local $\mathrm{pH}$ and concentration of species near the electrode surface were calculated using the numerical approach introduced by Gupta et al.[23] The model and equations used for the calculations are given at Chapter 2.

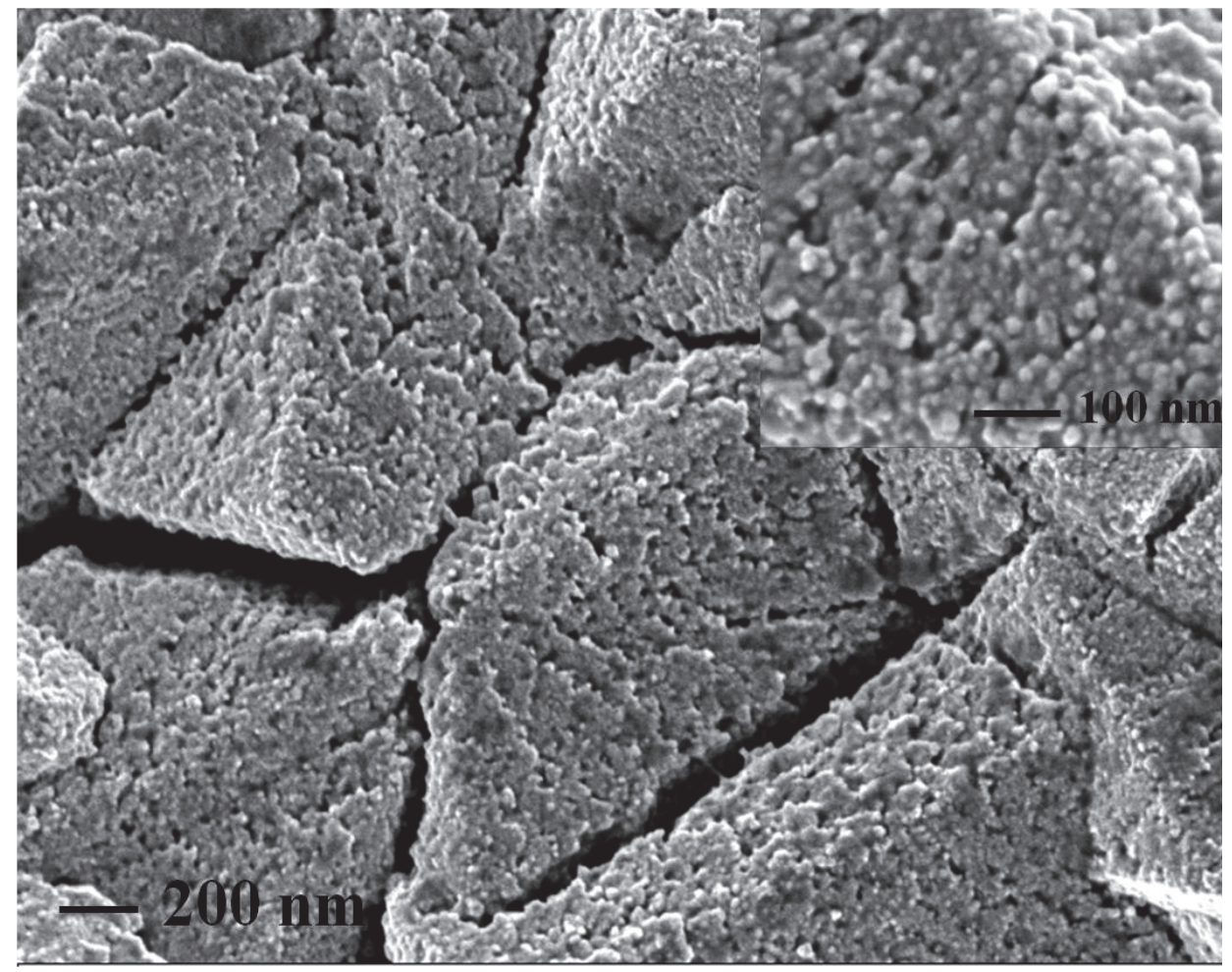

Figure 1: SEM images of copper nanoparticles prepared by reduction of $\mathrm{Cu}_{2} \mathrm{O}$ film at $-1.2 \mathrm{~V}$ vs $\mathrm{Ag} / \mathrm{AgCl}$. 

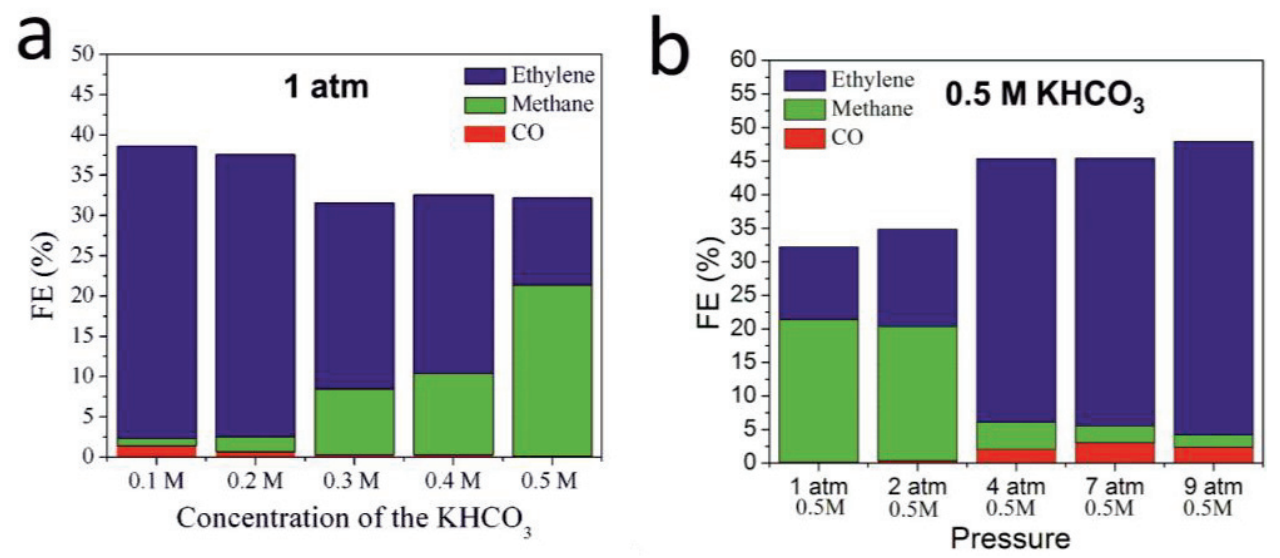

Figure 2: a) Product distributions of $\mathrm{CO}_{2}$ reduction as a function of electrolyte concentration at $1 \mathrm{~atm}, \mathrm{~b}$ ) as a function of $\mathrm{CO}_{2}$ pressure in $0.5 \mathrm{M} \mathrm{KHCO}_{3}$ at an applied potential of $0.5 \mathrm{M} \mathrm{KHCO}_{3}$ $(-1.8 \mathrm{Vvs} \mathrm{Ag} / \mathrm{AgCl})$.

In Figure 2a the Faradaic efficiency (FE) of hydrocarbons at $-1.8 \mathrm{~V}$ vs Ag/ $\mathrm{AgCl}$ as a function of electrolyte concentration is shown for similarly prepared electrodes with an initial oxide thickness of $6 \mu \mathrm{m}\left(5 \mathrm{C} / \mathrm{cm}^{2}\right)$. The high ethylene over methane ratio $(\approx 30)$ observed at low electrolyte concentration changes to methane being the dominant product at high electrolyte concentration. Figure $2 \mathrm{~b}$ shows the change in hydrocarbon selectivity as a function of pressure in $0.5 \mathrm{M} \mathrm{KHCO}_{3}$. At $9 \mathrm{~atm}$, the selectivity is comparable to that observed at $1 \mathrm{~atm}$ and $0.1 \mathrm{M} \mathrm{KHCO}_{3}$, with FE's of 44\% ethylene and $2 \%$ methane. Complete reversibility in selectivity, is demonstrated by experiments on one and the same electrode (not shown here). Based on the results, any permanent morphological changes that might occur as a result of exposure of the copper surface to high electrolyte concentrations, high currents, and high $\mathrm{CO}_{2}$ pressures, can be excluded.

Figure $3 \mathrm{a}$ and $3 \mathrm{~b}$ show the $\mathrm{FE}$ of hydrocarbons and hydrogen vs time at an applied voltage of $-1.8 \mathrm{~V}$ vs $\mathrm{Ag} / \mathrm{AgCl}$ in $0.1 \mathrm{M}$ and $0.5 \mathrm{M}$ of $\mathrm{KHCO}_{3}$, respectively. The electrode shows no sign of deactivation over the course of 4 hours at $0.1 \mathrm{M}^{\circ} \mathrm{KHCO}_{3}$, whereas the same electrode producing predominantly methane in $0.5 \mathrm{M} \mathrm{KHCO}_{3}$ deactivates significantly in time with respect to $\mathrm{CO}_{2}$ reduction efficiency. Hydrogen production is not affected, and in fact slowly increases as a function of reaction time. In Figure $3 c$, the change in quantity of hydrocarbons is given as a function of time for 

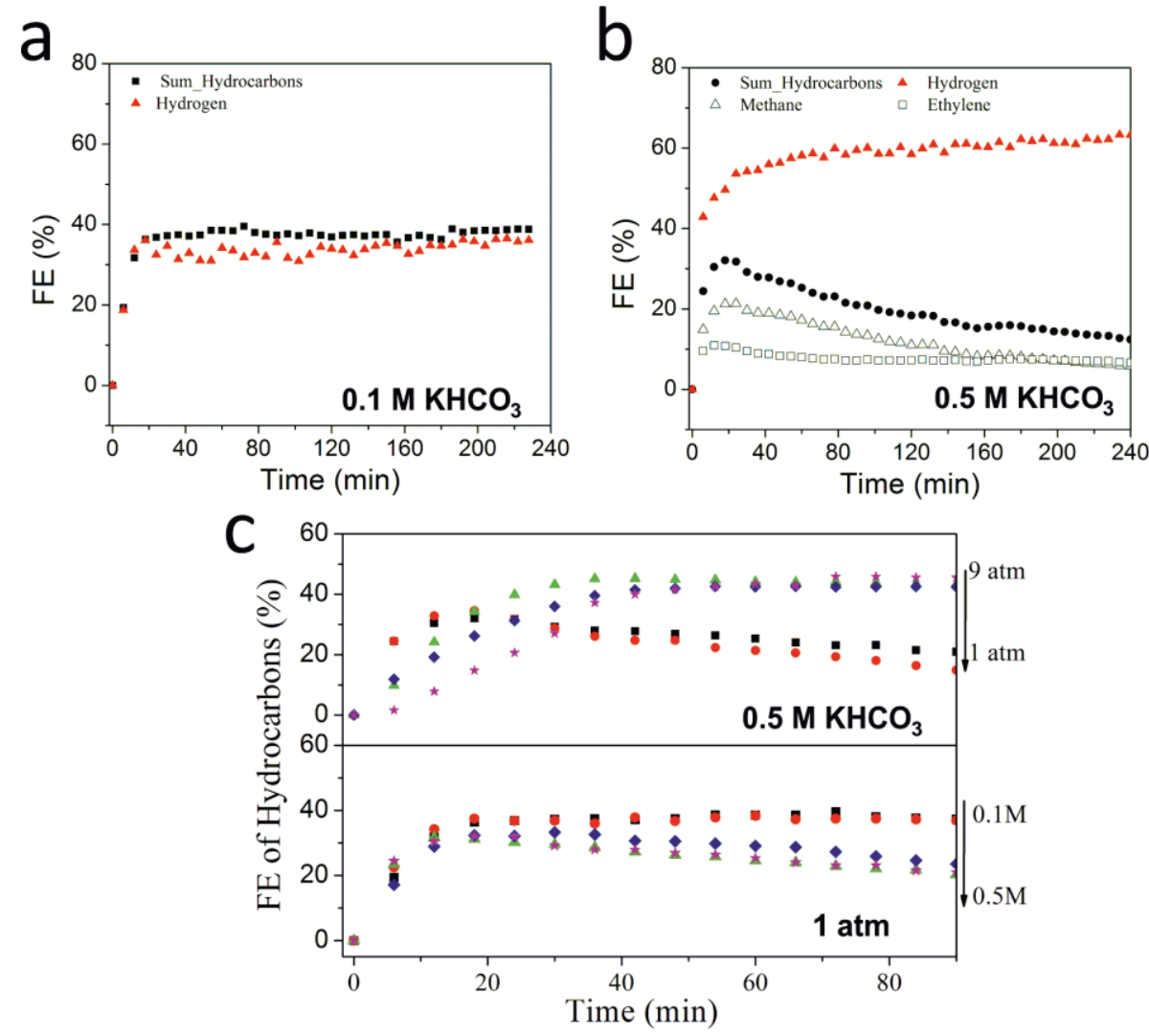

Figure 3: FE of hydrocarbons and hydrogen vs time in a) $0.1 \mathrm{M} \mathrm{KHCO}_{3}$ b) $0.5 \mathrm{M} \mathrm{KHCO}_{3}$ at an applied potential of $-1.8 \mathrm{~V} \mathrm{Ag} / \mathrm{AgCl}$. c) $\mathrm{FE}$ of hydrocarbons vs time for all experiments performed in Figure $2 \mathrm{a}$ and $2 \mathrm{~b}$.

different electrolyte concentrations (0.1-0.5 M) and pressures (1-9atm). Similar trends are consistently observed, where slow deactivation was observed when appreciable amounts of methane were produced. One can argue that this might be the result of an increase in the amount of impurities with the increasing electrolyte concentration. However, similar trends at higher pressures with $0.5 \mathrm{M}$ electrolyte concentration were consistently observed. The time needed to reach steady state increased with the increasing pressure and the slow deactivation of the electrodes before reaching the steady state might be the reason for the lower FE when methane is the dominant product. So the FE should not be taken too straightforward rather the ratios are important. No absolute relation has been observed with the amount of methane produced and the rate of deactivation. However the deactivation rate of methane was 
always found to be faster than that of ethylene. All the electrodes produces more or less methane therefore we don't exclude the probability of deactivation of all electrodes in very long time intervals.

The $\mathrm{pH}$ at the electrode surface during electrochemical reduction is computed as a function of electrolyte concentration for current densities of $5 \mathrm{~mA} / \mathrm{cm}^{2}, 10 \mathrm{~mA} / \mathrm{cm}^{2}$ and $15 \mathrm{~mA} / \mathrm{cm}^{2}$ at $1 \mathrm{~atm}$ and $9 \mathrm{~atm}$ (Figure 4). The reason for the high local $\mathrm{pH}$ near the electrode surface is the release of $\mathrm{OH}^{-}+$during $\mathrm{CO}_{2}$ reduction and hydrogen evolution, which increases with higher current density.[23] The $\mathrm{pH}$ variations at the electrode surface, compared to the bulk $\mathrm{pH}$, become less with higher bicarbonate concentrations as a result of the increasing buffer capacity of the solution. An increase in $\mathrm{CO}_{2}$ concentration at high pressures is expected to contribute to the buffer capacity of the solution, by forming bicarbonate though reaction with $\mathrm{OH}^{-}$, but also leads to higher local current densities. We will argue below that these strong variations in $\mathrm{pH}$ near the electrode surface can explain the different selectivities observed.[24, 25] In addition, the presence of nanoparticles at the surface increases the roughness (by a factor of $\approx 16$ ) and thus the corresponding local current density. When nanoparticles

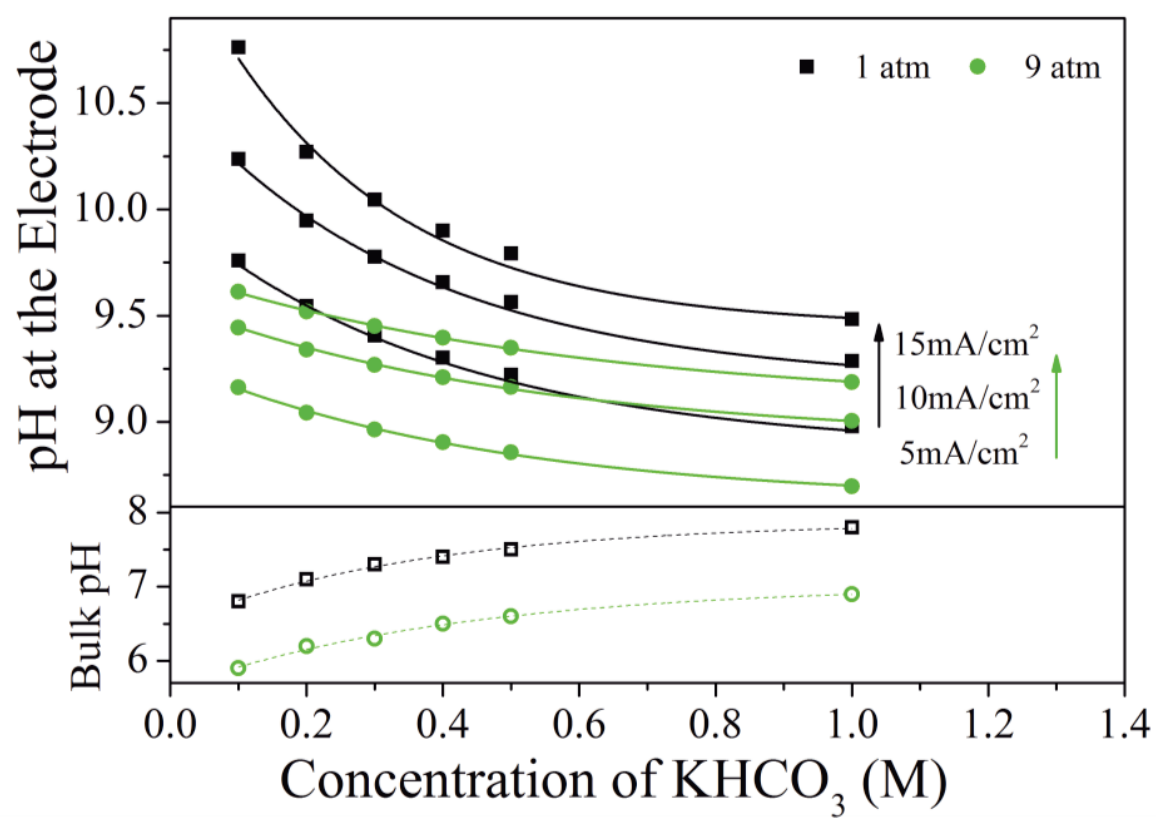

Figure 4: Estimated (local) $\mathrm{pH}$ at the electrode surface as a function electrolyte concentration at different current densities and pressures, and the corresponding bulk $\mathrm{pH}$ for different electrolyte concentrations. 
are present on the electrode surface, they individually form diffusion spheres. The overlap of these diffusion spheres result in formation of a continuous diffusion layer.[26] So the electrode can be considered as planar and the diffusion equations can be written accordingly.[27]

A proposed reaction scheme for electrochemical $\mathrm{CO}_{2}$ reduction is given in Scheme 1. Hori et al. reported that methane is the dominant product when electropolished polycrystalline copper is used at $-1.8 \mathrm{~V}$ vs $\mathrm{Ag} / \mathrm{AgCl}$ in bicarbonate solutions.[28] Concerning the pathway leading to the formation of methane, Density Functional Theory (DFT) calculations on $\mathrm{Cu}(211)$ and $\mathrm{Cu}(100)$ surfaces indicate that the protonation of $\mathrm{CO}$ to $\mathrm{CHO}$ on the electrode surface is the rate determining step for methane formation.[29] This is in agreement with experimental observations that methane formation from $\mathrm{CO}$ reduction involves a concerted proton-electron transfer,

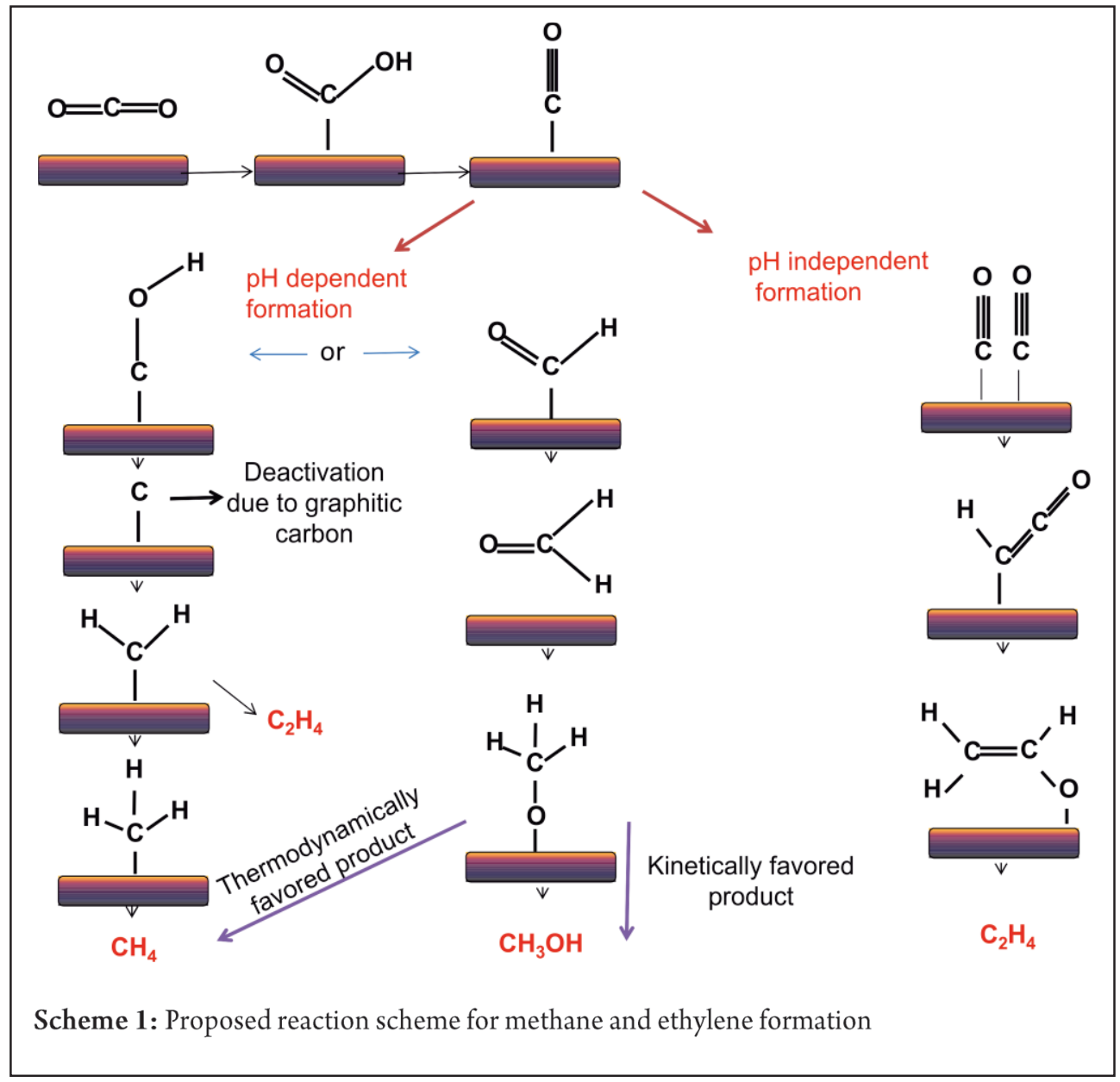


making its rate $\mathrm{pH}$ dependent on the NHE scale (but $\mathrm{pH}$ independent on the RHE scale).[30-32] Schouten et al. showed that at high potentials the formation of methane and ethylene from $\mathrm{CO}$ occur via a shared intermediate (presumably $\mathrm{HCO}$ or $\mathrm{COH}$ ) on $\mathrm{Cu}(111)$ and $\mathrm{Cu}(100)$ surfaces, with identical $\mathrm{pH}$ dependence. [30, 31]

An alternative route to ethylene, a rate-determining CO coupling mechanism, is proposed to take place on $\mathrm{Cu}(100)$ surfaces at low overpotential in alkaline media. [8] This step does not include simultaneous proton transfer, and is therefore $\mathrm{pH}$ independent on the NHE scale but $\mathrm{pH}$ dependent on the RHE scale, in the sense that the reaction is favored in alkaline media.[10,24] The RHE is the thermodynamically relevant potential scale to compare $\mathrm{pH}$ dependent reactions because it automatically corrects for the $\mathrm{pH}$ dependent equilibrium potential of the overall reaction. As a result, a reaction that involves electron transfer but no proton transfer is $\mathrm{pH}$ dependent on the RHE scale. The formation of ethylene has been found to be especially high in the presence of $\mathrm{Cu}(100)$ terrace sites, although there is no clear agreement between longterm electrolysis experiments and shorter-term voltammetry measurements on the optimal (100) terrace width. [33],[34]

The identification of two potential pathways for ethylene formation, i.e. through a $\mathrm{HCO} / \mathrm{COH}$ intermediate or $\mathrm{CO}$ dimerization, is in agreement with the results of the present study. The formation of ethylene through the $\mathrm{CO}$ coupling mechanism is favored at low concentrations of electrolyte due to the correspondingly high local $\mathrm{pH}$ near the electrode surface (Figure 2a). Such an effect was also emphasized in previous studies where electrolytes with low buffer capacity favor ethylene formation on smooth copper electrodes.[24, 25] In addition, very recently ethylene formation was reported be favored over methane in very dilute bicarbonate solutions ( $\left.0.05 \mathrm{M} \mathrm{KHCO}_{3}\right)$ on mechanically polished copper surfaces. [35] Increasing the buffer capacity of the solution favors the pathway towards methane, as a result of the lower $\mathrm{pH}$ at the electrode surface. The remaining ethylene FE (Fig. 1a) might now originate from either the $\mathrm{HCO} / \mathrm{COH}$ intermediate, or still $\mathrm{CO}$ dimerization.

Higher $\mathrm{CO}_{2}$ pressures, even though calculated to result in a lower local $\mathrm{pH}$ at equal concentration of $\mathrm{KHCO}_{3}$, lead to ethylene most likely because of an increase in local $\mathrm{CO}$ concentration and corresponding $\mathrm{CO}$ surface coverage. This is also reflected by the increase in the amount of desorbed $\mathrm{CO}$ from the surface with increasing pressure (see Fig.1c). In addition, voltammetry studies (Figures 5a and 5b) show a significant reduction peak around $-1.1 \mathrm{~V}$ vs $\mathrm{Ag} / \mathrm{AgCl}$ with an onset potential around $-0.7 \mathrm{~V}$ vs $\mathrm{Ag} / \mathrm{AgCl}$ in linear sweep voltammetry curves in $0.1 \mathrm{M}$ and $0.5 \mathrm{M} \mathrm{KHCO}_{3}$ solutions, 
respectively, specifically at $\mathrm{CO}_{2}$ pressures larger than $2 \mathrm{~atm}$. On polycrystalline copper, usually no such characteristic peak is observed for $\mathrm{CO}_{2}$ reduction at $1 \mathrm{~atm}$, and the cathodic current mostly due to hydrogen evolution.[24] Indeed, the peak was not observed at $1 \mathrm{~atm}$, which is consistent with these previous reports.[18] The reduction peak emerging at elevated $\mathrm{CO}_{2}$ pressure is at similar potential as reported for phosphate buffers and high bicarbonate concentrations, in which the $\mathrm{CO}_{2}$ reduction peak was attributed to bicarbonate reduction and $\mathrm{CO}$ adsorption.[36, 37]

To gain more insight, long term product analysis was performed at -1.1 vs $\mathrm{Ag} / \mathrm{AgCl}$ as a function of increasing pressure (Figure $5 \mathrm{c}$ ). At high pressures more time is needed to reach steady state reactor behavior, but more importantly the $\mathrm{FE}$ of $\mathrm{CO}$ is boosted to $71 \%$ at 9 atm, compared to $20 \%$ at $1 \mathrm{~atm}$ in steady state conditions. The evolution of the reduction peak as a function of pressure follows a very similar trend

a)

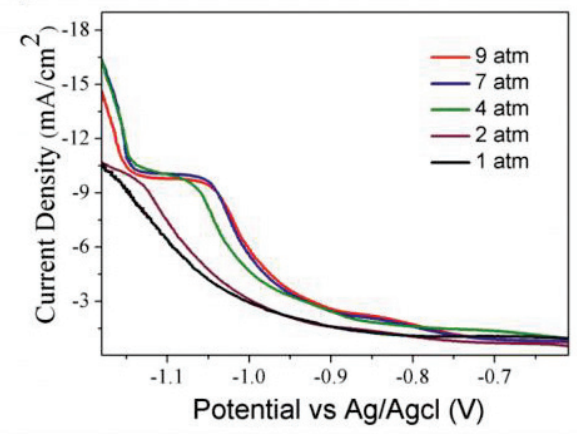

C) b)

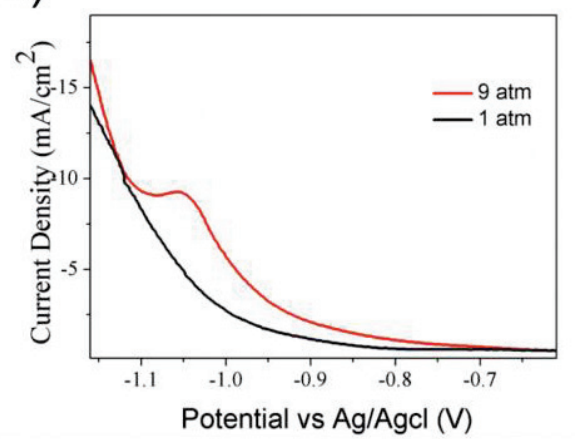

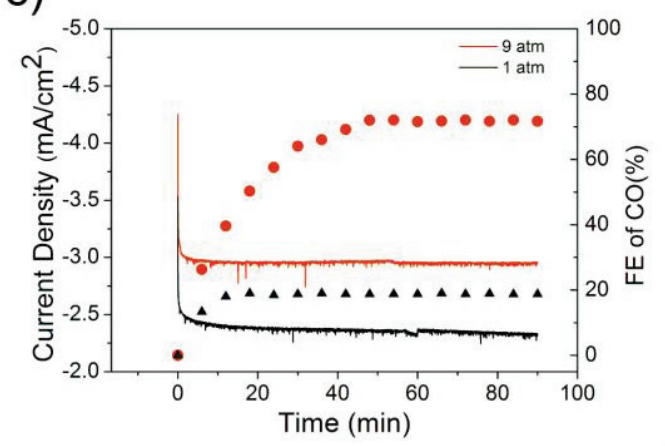

Figure 5: Linear polarization curves for copper nanoparticles in a) $0.1 \mathrm{MKHCO} 3$ and b) $0.5 \mathrm{M} \mathrm{KHCO} 3$ at different pressures with a scan rate of $50 \mathrm{mV} \mathrm{s}^{-1} . \mathrm{c}$ ) Change in current density (line) and $\mathrm{FE}$ (scattered) of $\mathrm{CO}$ production in $0.1 \mathrm{M} \mathrm{KHCO}_{3}$ at an applied of $-1.1 \mathrm{vs} \mathrm{Ag} / \mathrm{AgCl}$ for $1 \mathrm{~atm}$ and $9 \mathrm{~atm}$. 
with the selectivity in $\mathrm{CO}_{2}$ reduction (see Figure $2 b$ ). As the pressure goes up, ethylene formation is favored over methane at $-1.8 \mathrm{~V}$ (Figure $2 \mathrm{~b}$ ), in agreement with the reduction peak detected at these higher pressures at $-1.1 \mathrm{~V}$ attributed to the formation of $\mathrm{CO}$ (Figure $5 \mathrm{~b}$ ). The rate for $\mathrm{C}$-C coupling is likely influenced by the surface coverage and local $\mathrm{CO}$ concentration in addition to the energetics of the reaction.[15] The high $\mathrm{CO}$ selectivity of copper nanoparticle containing electrodes at elevated pressures and $-1.1 \mathrm{~V}$ vs $\mathrm{Ag} / \mathrm{AgCl}$ is thus consistent with the high ethylene selectivity observed at more negative potential $(-1.8 \mathrm{~V} \mathrm{Ag} / \mathrm{AgCl})$. From a practical point of view, these experiments show that nanoparticle covered $\mathrm{Cu}$ electrodes at moderate $\mathrm{CO}_{2}$ pressures might be an alternative candidate to $\mathrm{Ag}$, or $\mathrm{Au}$, if a high $\mathrm{CO}$ selectivity is desired.

The proposed mechanism for ethylene formation via $\mathrm{CO}$ dimerization raises the question why ethylene formation was not observed at low potentials. The onset potential for ethylene formation over nanoparticulate electrodes is around $-0.5 \mathrm{~V}$ vs reversible hydrogen electrode (RHE) from $\mathrm{CO}_{2}$ (See Chapter 3), whereas ethylene formation from $\mathrm{CO}$ is already observed at $-0.2 \mathrm{~V}$ vs $\mathrm{RHE}$ on $\mathrm{Cu}(100)$. [8] This suggests that the first electron transfer, converting $\mathrm{CO}_{2}$ into $\mathrm{CO}$ is the overall rate determining step, which involves a concerted proton-coupled electron transfer,[38] whereas the ethylene/methane ratio is determined by the thermodynamic and kinetic barriers associated with the different pathways and the reactant concentrations (protons, dissolved $\mathrm{CO}$ ) near the electrode surface. In addition, a high local $\mathrm{pH}$ may also affect the plots vs RHE scale, especially at high current densities or potentials. A local $\mathrm{pH}$ of 11 for example would bring an extra electrochemical potential difference of $\approx 0.25 \mathrm{~V}$ with respect to the bulk $\mathrm{pH}$ in a $0.1 \mathrm{M} \mathrm{KHCO}_{3}$ solution.

The observation that the deactivation of the electrodes depends on the product made, also suggests that methane and ethylene are formed via different pathways. Poisoning has been explained by cathodic deposition of metal impurities during electroreduction by Hori et al.[39] However, due to the very high electrochemically active area of our electrodes, the electrodes are likely not very sensitive to this type of poisoning. In addition to metal deposition, several research groups proposed the deactivation of copper electrodes by graphitic carbon species formed via decomposition of intermediates.[40-42] The product-selective deactivation repetitively observed in the present study, suggests that the $\mathrm{COH}$ intermediate, relevant in the $\mathrm{pH}$ dependent pathway towards methane on the NHE scale, may be the cause of the deactivation, since the $\mathrm{pH}$ independent $\mathrm{CO}$ dimerization mechanism appears to be less sensitive to electrode poisoning. $[3,42]$ There are various previous papers showing that electrodes producing ethylene are stable $[16,18,22,43]$ whereas 
slow deactivation is reported on roughened electrodes where methane is the major product. $[16,41,43]$

The fact that the selectivity is governed so sensitively by the process parameters not only clarifies the formation of ethylene on copper nanoparticles in the present study, but likely also the ethylene selectivity observed on roughened copper surfaces prepared ex-situ by copper electrodeposition, anodization, pulsed electrolysis, and thermal oxidation.[16-18, 20-22, 41, 44, 45] On roughened electrodes, the local current density is higher, leading to a very high local $\mathrm{pH}$ favoring ethylene formation, while methane production is relatively low. Further increasing the roughness also leads to ethane formation. [19, 22] The pathway towards ethane is currently under investigation, but likely related to ethylene hydrogenation.

In summary, we demonstrate that ethylene formation over copper oxide derived copper electrodes can be favored by i) a low electrolyte concentration and thus buffer capacity, ii) a high local current density (such as on rough electrodes), and iii) high $\mathrm{CO}_{2}$ pressures. In addition, the experiments show that poisonous species are formed primarily in the methane formation pathway. Local concentrations of reactants $\left(\mathrm{H}^{+}\right.$, $\mathrm{CO}$ ) should be taken into account when mechanistic interpretation of $\mathrm{CO}_{2}$ reduction results is addressed, in particular in the case of roughened copper surfaces.

\subsection{References}

1. Kumar, B., et al., Renewable and metal-free carbon nanofibre catalysts for carbon dioxide reduction. Nature Communications, 2013. 4.

2. DiMeglio, J.L. and J. Rosenthal, Selective Conversion of $\mathrm{CO}_{2}$ to $\mathrm{CO}$ with High Efficiency Using an Inexpensive Bismuth-Based Electrocatalyst. Journal of the American Chemical Society, 2013. 135(24): p. 8798-8801.

3. Nie, X., et al., Selectivity of $\mathrm{CO}_{2}$ Reduction on Copper Electrodes: The Role of the Kinetics of Elementary Steps. Angewandte Chemie International Edition, 2013. 52(9): p. 2459-2462.

4. Kondratenko, E.V., et al., Status and perspectives of $\mathrm{CO}_{2}$ conversion into fuels and chemicals by catalytic, photocatalytic and electrocatalytic processes. Energy \& Environmental Science, 2013. 6(11): p. 3112-3135.

5. Whipple, D.T. and P.J. Kenis, Prospects of $\mathrm{CO}_{2}$ utilization via direct heterogeneous electrochemical reduction. The Journal of Physical Chemistry Letters, 2010. 1(24): p. 3451-3458. 
6. Zhang, S., P. Kang, and T.J. Meyer, Nano-Structured Tin Catalysts for Selective Electrochemical Reduction of Carbon Dioxide to Formate. Journal of the American Chemical Society, 2014.

7. Rosen, B.A., et al., Ionic Liquid-Mediated Selective Conversion of $\mathrm{CO}_{2}$ to $\mathrm{CO}$ at Low Overpotentials. Science, 2011. 334(6056): p. 643-644.

8. Schouten, K.J.P., et al., Two pathways for the formation of ethylene in CO reduction on single-crystal copper electrodes. Journal of the American Chemical Society, 2012. 134(24): p. 9864-9867.

9. Li, C.W., J. Ciston, and M.W. Kanan, Electroreduction of carbon monoxide to liquid fuel on oxide-derived nanocrystalline copper. Nature, 2014. 508(7497): p. 504-507.

10. Calle-Vallejo, F. and M. Koper, Theoretical Considerations on the Electroreduction of $\mathrm{CO}$ to $\mathrm{C} 2$ Species on $\mathrm{Cu}$ (100) Electrodes. Angewandte Chemie, 2013. 125(28): p. 7423-7426.

11. Montoya, J.H., A.A. Peterson, and J.K. Nørskov, Insights into C-C Coupling in CO2 Electroreduction on Copper Electrodes. ChemCatChem, 2013. 5(3): p. 737-742.

12. Schouten, K.J.P., F. Calle-Vallejo, and M. Koper, A Step Closer to the Electrochemical Production of Liquid Fuels. Angew. Chem., Int. Ed., 2014.

13. Hori, Y., K. Kikuchi, and S. Suzuki, Production of $\mathrm{CO}$ and $\mathrm{CH} 4$ in electrochemical reduction of $\mathrm{CO}_{2}$ at metal electrodes in aqueous hydrogencarbonate solution. Chemistry Letters, 1985(11): p. 1695-1698.

14. Shibata, H., J.A. Moulijn, and G. Mul, Enabling electrocatalytic Fischer-Tropsch synthesis from carbon dioxide over copper-based electrodes. Catalysis Letters, 2008. 123(3-4): p. 186-192.

15. Kuhl, K.P., et al., New insights into the electrochemical reduction of carbon dioxide on metallic copper surfaces. Energy Environ. Sci., 2012. 5(5): p. 70507059 .

16. Goncalves, M., et al., Selective electrochemical conversion of $\mathrm{CO}_{2}$ to $\mathrm{C} 2$ hydrocarbons. Energy Conversion and Management, 2010. 51(1): p. 30-32.

17. Gonçalves, M., et al., Electrochemical conversion of $\mathrm{CO}<\mathrm{sub}>2</$ sub $>$ to $\mathrm{C} 2$ hydrocarbons using different ex situ copper electrodeposits. Electrochimica Acta, 2013. 102: p. 388-392.

18. Tang, W., et al., The importance of surface morphology in controlling the selectivity of polycrystalline copper for $\mathrm{CO}_{2}$ electroreduction. Physical Chemistry Chemical Physics, 2012. 14(1): p. 76-81.

19. $\mathrm{Li}, \mathrm{C} . \mathrm{W}$. and M.W. Kanan, $\mathrm{CO}_{2}$ reduction at low overpotential on $\mathrm{Cu}$ electrodes resulting from the reduction of thick $\mathrm{Cu}_{2} \mathrm{O}$ films. Journal of the American Chemical Society, 2012. 134(17): p. 7231-7234. 
20. Sen, S., D. Liu, and G.T.R. Palmore, Electrochemical Reduction of $\mathrm{CO}_{2}$ at Copper Nanofoams. ACS Catal., 2014. 4: p. 3091-3095.

21. Baturina, O., et al., $\mathrm{CO}_{2}$ electroreduction to hydrocarbons on carbon-supported $\mathrm{Cu}$ nanoparticles. ACS Catal., 2014.

22. Kas, R, et al., Electrochemical $\mathrm{CO}_{2}$ reduction on $\mathrm{Cu}_{2} \mathrm{O}$-derived copper nanoparticles: controlling the catalytic selectivity of hydrocarbons. Physical Chemistry Chemical Physics, 2014. 16(24): p. 12194-12201.

23. Gupta, N., M. Gattrell, and B. MacDougall, Calculation for the cathode surface concentrations in the electrochemical reduction of $\mathrm{CO}_{2}$ in $\mathrm{KHCO}_{3}$ solutions. Journal of Applied Electrochemistry, 2006. 36(2): p. 161-172.

24. Gattrell, M., N. Gupta, and A. Co, A review of the aqueous electrochemical reduction of $\mathrm{CO}_{2}$ to hydrocarbons at copper. Journal of Electroanalytical Chemistry, 2006. 594(1): p. 1-19.

25. Hori, Y., A. Murata, and R. Takahashi, Formation of hydrocarbons in the electrochemical reduction of carbon dioxide at a copper electrode in aqueous solution. J. Chem. Soc., Faraday Trans. 1, 1989. 85(8): p. 2309-2326.

26. Wickman, B., et al., Fabrication of $P t / R u$ Nanoparticle Pair Arrays with Controlled Separation and their Electrocatalytic Properties. ACS Nano, 2011. 5(4): p. 2547-2558.

27. Kleijn, S.E., et al., Electrochemistry of nanoparticles. Angewandte Chemie International Edition, 2014. 53(14): p. 3558-3586.

28. Hori, Y., Electrochemical CO2 reduction on metal electrodes, in Modern aspects of electrochemistry 2008, Springer. p. 89-189.

29. Peterson, A.A., et al., How copper catalyzes the electroreduction of carbon dioxide into hydrocarbon fuels. Energy Environ. Sci., 2010. 3(9): p. 1311-1315.

30. Schouten, K.J.P., E. Pérez Gallent, and M.T.M. Koper, The influence of $p H$ on the reduction of $\mathrm{CO}$ and $\mathrm{CO}_{2}$ to hydrocarbons on copper electrodes. Journal of Electroanalytical Chemistry, 2013.

31. Hori, Y., et al., Electrochemical reduction of $\mathrm{CO}$ at a copper electrode. Journal of Physical Chemistry B, 1997. 101(36): p. 7075-7081.

32. Koper, M.T.M., Theory of multiple proton-electron transfer reactions and its implications for electrocatalysis. Chem. Sci., 2013. 4(7): p. 2710-2723.

33. Hori, Y., et al., Electrochemical reduction of carbon dioxide at various series of copper single crystal electrodes. Journal of Molecular Catalysis A: Chemical, 2003. 199(1): p. 39-47.

34. Schouten, K.J.P., E. Perez Gallent, and M.T.M. Koper, Structure Sensitivity of the Electrochemical Reduction of Carbon Monoxide on Copper Single Crystals. ACS Catal., 2013. 3(6): p. 1292-1295. 
35. Varela, A.S., et al., Controlling the selectivity of $\mathrm{CO}_{2}$ electroreduction on copper: The effect of the electrolyte concentration and the importance of the local $\mathrm{pH}$. Catalysis Today.

36. Kortlever, R, et al., Electrochemical carbon dioxide and bicarbonate reduction on copper in weakly alkaline media. Journal of Solid State Electrochemistry, 2013. 17(7): p. 1843-1849.

37. Hori, Y., et al., Enhanced formation of ethylene and alcohols at ambient temperature and pressure in electrochemical reduction of carbon dioxide at a copper electrode. Journal of the Chemical Society, Chemical Communications, 1988(1): p. 17-19.

38. Peterson, A.A., et al., How copper catalyzes the electroreduction of carbon dioxide into hydrocarbon fuels. Energy \& Environmental Science, 2010. 3(9): p. 13111315.

39. Hori, Y., et al., "Deactivation of copper electrode" in electrochemical reduction of $\mathrm{CO}_{2}$. Electrochimica Acta, 2005. 50(27): p. 5354-5369.

40. DeWulf, D.W., T. Jin, and A.J. Bard, Electrochemical and surface studies of carbon dioxide reduction to methane and ethylene at copper electrodes in aqueous solutions. Journal of the Electrochemical Society, 1989. 136(6): p. 1686-1691.

41. Kyriacou, G. and A. Anagnostopoulos, Electroreduction of $\mathrm{CO}_{2}$ on differently prepared copper electrodes: The influence of electrode treatment on the current efficiences. Journal of Electroanalytical Chemistry, 1992. 322(1): p. 233-246.

42. Xie, J.-F., et al., Efficient electrochemical $\mathrm{CO}_{2}$ reduction on a unique chrysanthemum-like $\mathrm{Cu}$ nanoflower electrode and direct observation of carbon deposite. Electrochimica Acta, 2014.

43. Chen, C.S., et al., Stable and selective electrochemical reduction of carbon dioxide to ethylene on copper mesocrystals. Catal. Sci. Technol., 2014.

44. Bugayong, J. and G.L. Griffin, Electrochemical Reduction of $\mathrm{CO}_{2}$ Using Supported Cu2O Nanoparticles. ECS Trans., 2013. 58(2): p. 81-89.

45. Griffin, G.L. and J. Bugayong. Electrochemical Reduction of $\mathrm{CO}_{2}$ using Copper Oxide Nanoparticles supported on Glassy Carbon Electrodes. in MRS Online Proc. Libr. 2014. Cambridge Univ Press. 



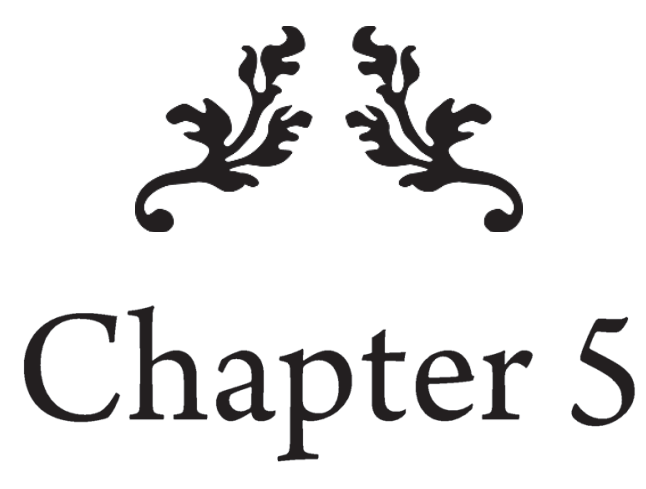

On the formation of ethane over rough copper electrodes

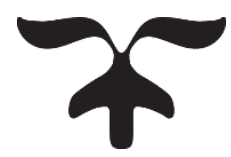




\begin{abstract}
Ethane is a significant hydrocarbon product from carbon dioxide electroreduction on rough copper electrodes, regardless of preparation method and morphology. We demonstrate that ethane is formed by electrochemical hydrogenation of ethylene. Voltammetry studies indicate that ethylene hydrogenation takes place simultaneously with hydrogen evolution whereas online electrochemical mass spectrometry studies confirm the formation of ethane on both smooth and rough surfaces in ethylene saturated solutions. Carbon dioxide reduction experiments in the presence of iodide, a strongly absorbing ion on copper surfaces, results in higher ethylene desorption rates, and thus reduced formation of ethane. Scanning electron microscopy and atomic force microscopy revealed that the surface is composed of an almost continuous film of highly packed nanoparticles when the catalyst loading is high, i.e. thicker oxide films, were used. We propose the origin for the formation of ethane might be mesoscopic, rather than catalytic, where re-adsorption of ethylene on very rough surfaces leads to hydrogenation, rather than conversion of surface bound intermediates.
\end{abstract}




\subsection{Introduction}

Highly energy efficient $\mathrm{CO}_{2}$ reduction to hydrocarbons is necessary to compete with the current technologies used in the chemical industry based on fossil resources. A high energy efficiency would bring along the requirement of a high selectivity as well.[1] However, the product distribution of smooth or rough copper electrodes at high potentials are quite broad. Up to 16 different products were reported on electropolished smooth copper electrodes when very sensitive methodologies were used.[2] Even though the distribution of the products were significantly different, a broad range of molecules, mostly $\mathrm{C}_{2}$ products, were also reported on rough copper electrodes.[3-5] Most of these compounds have low faradaic efficiency (FE) $(<1 \%)$ so they might be tolerable for large scale production. Ethane, on the other hand, is increasingly reported recently as one of the major products of electrochemical $\mathrm{CO}_{2}$ reduction on rough copper surfaces. [5] Ethane formation $(<0.1 \%)$ on copper surfaces was first reported by Hori et al. when the surface of the electrodes was roughened by thermal oxidation and subsequent hydrogenation at elevated temperatures[6]. With the recent development of nanostructured metal electrodes, appreciable amounts of ethane ( $>10 \%)$ were reported to be formed, depending on the degree of roughness. [5, 7] Independent studies showed ethane was formed at the expense of ethylene, when the roughness increased, regardless of the preparation method.[8-10] This is intriguing in the sense that ethane was never reported for smooth polycrystalline copper, or any single crystals of copper.[11,12] To the best of our knowledge, detailed investigations of ethane formation on copper surfaces have as of yet not been reported in the literature.

The production of ethane, particularly at the expense of ethylene, obviously has very little industrial interest. Ethylene is one of the most important raw chemicals of the chemical industry, for example in the production of common polymers and molecules by using versatile double bond chemistry. Besides, many researchers around the world aim to find a suitable catalyst for dehydrogenation of ethane to ethylene, since the currently used steam cracking method consumes a lot of energy.[13] Recently, Schouten et al. showed it is possible to produce ethylene at low potentials albeit by starting with $\mathrm{CO}$ which is a well-recognized intermediate for oxygenates and hydrocarbons.[14] Inspired by this, Li et al. showed it is possible to produce ethanol up to a faradaic efficiency (FE) of $57 \%$ by $\mathrm{CO}$ electroreduction, while ethylene and ethane were formed as co-product.[15] Any industrial electrocatalyst to be used in the future in electrochemical $\mathrm{CO}_{2}$ or $\mathrm{CO}$ reduction most likely will need to have a very high 
electrochemically active surface area, associated with a high surface roughness. Hence, it is very important to fundamentally understand how ethane is formed on rough surfaces to be able to enhance selectivity to ethylene.

Recent calculations on $\mathrm{C}-\mathrm{C}$ coupling from $\mathrm{CO}$ on $\mathrm{Cu}(211)$ surfaces suggest the kinetic barriers for coupling are strongly influenced by the degree of hydrogenation of the adsorbed CO.[16] These kinetic barriers tend to decrease with increasing degree of the surface bound $\mathrm{CO}$ hydrogenation, which can favor ethane. However, the absence of methane formation on the electrodes where ethane is formed suggest the formation is unlikely to occur via the formation of adsorbed $-\mathrm{CH}_{3}$, which is proposed as an intermediate for methane formation.[17] The hydrogenation appears to take place after the $\mathrm{C}-\mathrm{C}$ coupling, for example by further reduction of ethylene. By using voltammetry techniques and online mass spectroscopy, we verified the hypothesis of ethylene reduction on rough and smooth copper electrodes in the present study. Moreover, to gain insight on the formation of ethane directly from $\mathrm{CO}_{2}$, we performed long term electrolysis experiments in the presence of a strongly adsorbing anion, and at variable flow rate of $\mathrm{CO}_{2}$.

\subsection{Results and Discussion}

\subsubsection{Electrochemical Reduction of Ethylene to Ethane}

Cyclic voltammetry curves of nanoparticle covered surfaces in ethylene or nitrogen saturated solutions of $0.1 \mathrm{M} \mathrm{KHCO}_{3}$ are given in Figure 1a. The voltammetry curves in nitrogen or ethylene purged solutions are similar. By using a Pourbaix diagram of copper, the peaks can be assigned to oxidation and reduction of copper and its oxides, respectively, which is in agreement with previous studies on copper electrodes.[18] Scanning to sufficiently high anodic potentials $(>0.7 \mathrm{~V})$ copper oxidation and $\mathrm{Cu}^{2+}$ dissolution takes place simultaneously. As the potential is scanned to less positive potentials, the relatively weak first peak centered at $0.5 \mathrm{~V}$ vs RHE can be assigned to the transformation of copper oxide $(\mathrm{CuO})$ to cuprous oxide $\left(\mathrm{Cu}_{2} \mathrm{O}\right)$. Then $\mathrm{Cu}_{2} \mathrm{O}$ decomposes to form metallic copper at slightly negative potentials, which has a standard reduction potential of $0.47 \mathrm{~V}$ vs RHE.[18] The absence of additional peaks in these scans can be explained by i) ethylene oxidation or reduction is insignificant on rough copper surfaces, or ii) ethylene reduction takes place simultaneously with hydrogen evolution or oxide reduction. 

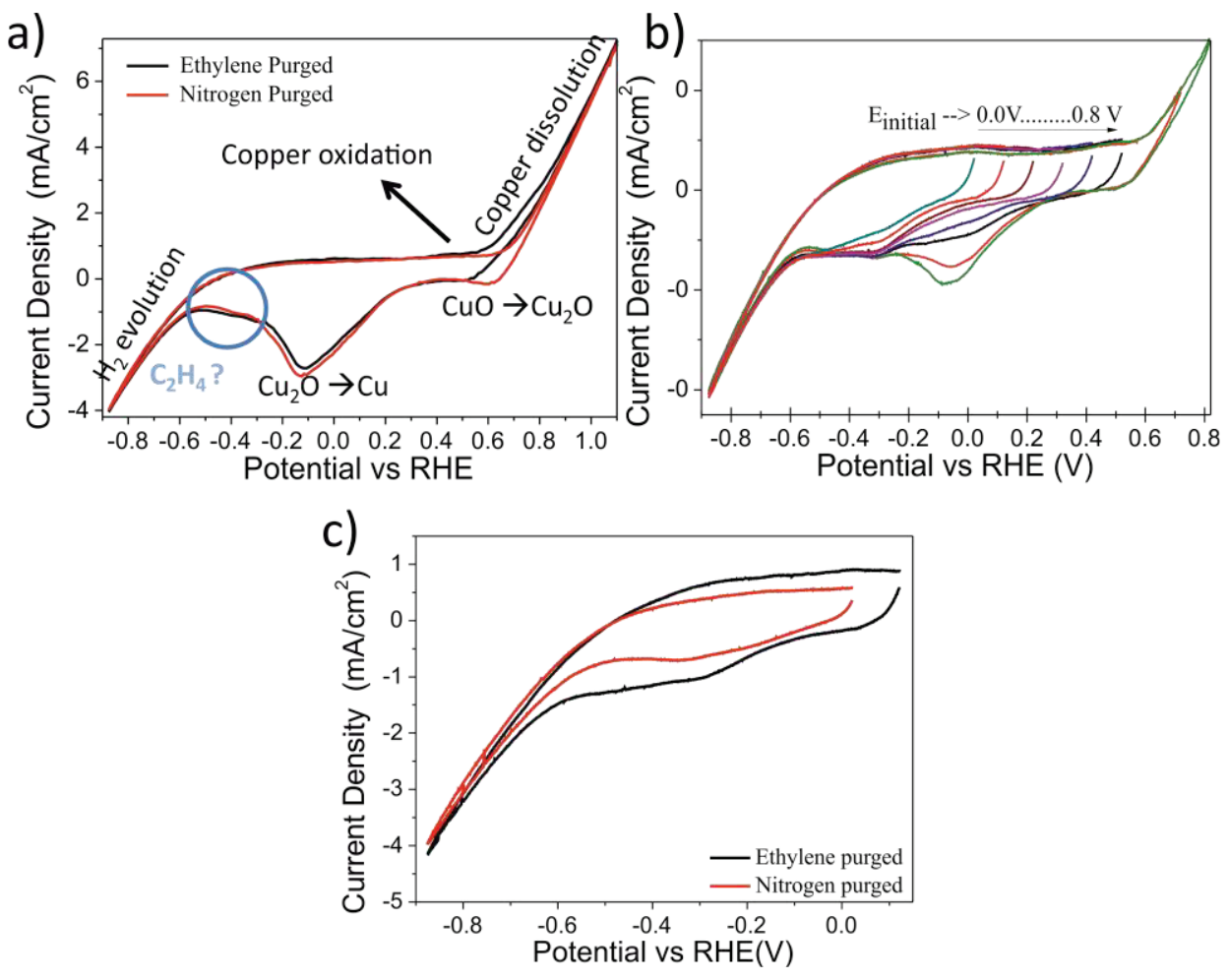

Figure 1: a) Cyclic voltammetry curves of nanoparticle covered surfaces in ethylene and nitrogen saturated $0.1 \mathrm{M} \mathrm{KHCO}_{3}$ solutions. b) Cyclic voltammetry curves of nanoparticle covered surfaces in ethylene saturated $0.1 \mathrm{M} \mathrm{KHCO}_{3}$ solutions by changing the initial potentials of the forward scan (correspondingly the final potentials).c) Cyclic voltammetry curves of nanoparticle covered surfaces in ethylene and nitrogen saturated $0.1 \mathrm{M} \mathrm{KHCO}_{3}$ solutions in the cathodic region. (Scan rates $50 \mathrm{mVs}^{-1}$ )

To investigate the second hypothesis, we varied the initial potentials of the voltammetric scans as shown in Figure $1 \mathrm{~b}$. Evidently, the intensity of the $\mathrm{Cu}_{2} \mathrm{O}$ decomposition peak dramatically declined as the initial potential was decreased to less positive potentials. The scans from less positive potentials in ethylene or nitrogen purged solutions are compared in Figure 1c. A very broad shoulder at low potentials can be seen in both ethylene or nitrogen purged solutions. The higher currents monitored in ethylene saturated solutions are an indication of simultaneous ethylene reduction with proton reduction. Attempts to analyze the reduction of ethylene on the electrode at constant potential by Gas Chromatography (GC) were unsuccessful, due to the broadening and saturation of the ethylene peak in the gas chromatogram, which 
eventually overlapped with the peak position of ethane. Therefore, we characterized the surfaces with online electrochemical mass spectrometry (OLEMS) which detects the volatile products desorbed from an electrode surface as a function of the applied potential.

In Figure 2a, ion currents of the mass fragments associated with volatile products are presented, definitively showing the feasibility of electrochemical reduction of ethylene on copper nanoparticles and polycrystalline copper. Two different products were detected, i.e. hydrogen $(\mathrm{m} / \mathrm{z}=2)$ and ethane $(\mathrm{m} / \mathrm{z}=29$ and 30$)$ to the expense of ethylene $(\mathrm{m} / \mathrm{z}=26)$. The ethane and hydrogen formation start at
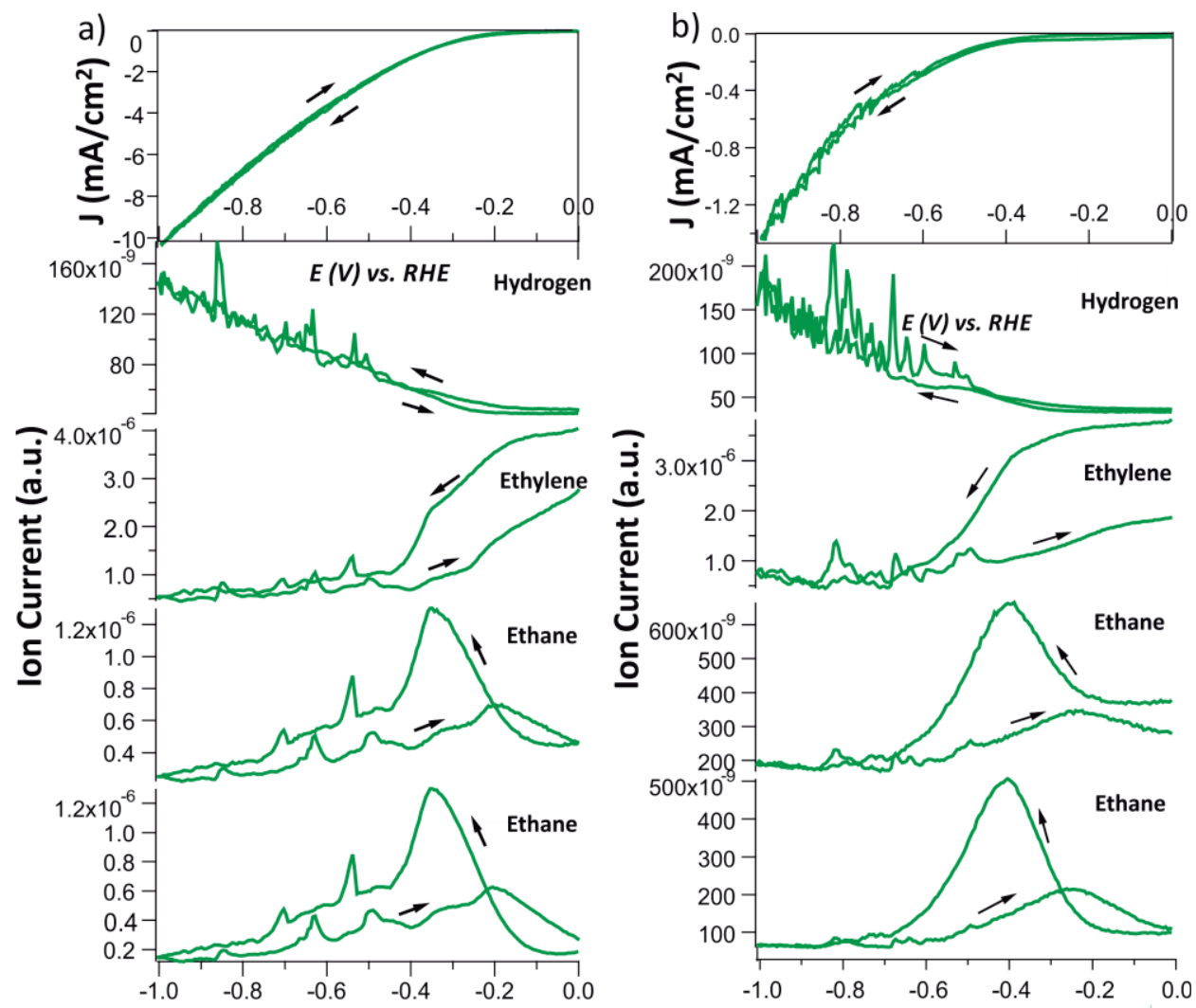

Figure 2: Reduction of ethylene in $0.1 \mathrm{M} \mathrm{KHCO}_{3}$ on a) Copper nanoparticles b) Polycrystalline copper. The top panels show the current density recorded during the potential scan $\left(1 \mathrm{mVs}^{-1}\right)$. Bottom panels show the associated mass fragments measured with OLEMS for the formation of hydrogen, ethane and consumption of ethylene. 
potentials around $-0.2 \mathrm{~V}$ vs RHE which is in agreement with the conclusions based on the voltammetry studies. Unfortunately, the concurrent hydrogen evolution makes it nearly impossible to extract the kinetic parameters such as exchange current density, Tafel constant, or order of reaction with respect to ethylene.

In catalysis, it is a common method to start with a stable (proposed) intermediate to elucidate the mechanism of the reaction.[19] If the reaction is considered to be composed of consecutive simple reactions, starting one of the stable intermediates must give the same product. So we can conclude that ethane is formed with the further hydrogenation of ethylene on rough copper surfaces. However, the hydrogenation of ethylene is also catalyzed by smooth copper surfaces as shown in Figure $2 b$, albeit with much lower efficiency. The intensity of mass fragments associated with ethane were much lower on smooth copper, which is attributed to the low electrochemically active surface area and evidenced by the lower current densities recorded. There is no significant change in onset potentials when the ion currents are normalized to the corresponding currents (not shown here). However, no ethane formation is reported on smooth copper surfaces from $\mathrm{CO}_{2}$ electroreduction even extremely sensitive methods are used.[2] In other words, both smooth and copper surfaces can catalyze ethylene hydrogenation by starting from ethylene, whereas ethane formation is observed only on sufficiently rough copper electrodes when $\mathrm{CO}_{2}$ is used as precursor. 


\subsubsection{Electrochemical $\mathrm{CO}_{2}$ reduction to Ethane}

To gain more insight in how ethane is formed when $\mathrm{CO}_{2}$ is used as precursor, we performed $\mathrm{CO}_{2}$ reduction experiments in the presence of a strongly adsorbing iodide ion. Iodide ion is known to severely reduce the hydrogenation rate of ethylene on metal electrodes by preventing the adsorption of ethylene.[20] First, we prepared even more rough surfaces by increasing the initial thickness of the oxide film in order to produce more ethane. Then we performed $\mathrm{CO}_{2}$ reduction experiments by changing the amount of $\mathrm{KI}$ in the solution. In Figure 3, the steady state concentrations of ethylene and ethane are given at constant applied current $\left(50 \mathrm{~mA} / \mathrm{cm}^{2}\right)$ in $0.1 \mathrm{M}$ $\mathrm{KHCO}_{3}$ solutions mixed with different amounts of potassium iodide. Remarkably, as a function of increasing iodide concentration, the amount of ethane decreases while the amount of ethylene increases. Increasing iodide concentration also decreases overall FE of hydrocarbons. However, the increase in the amount of ethylene indicates that the drop in ethane formation is not a result of overall decrease in hydrocarbon formation. Instead, more ethylene can desorb from the electrode surface before further hydrogenation to ethane occurs. The decrease in overall hydrocarbon production,

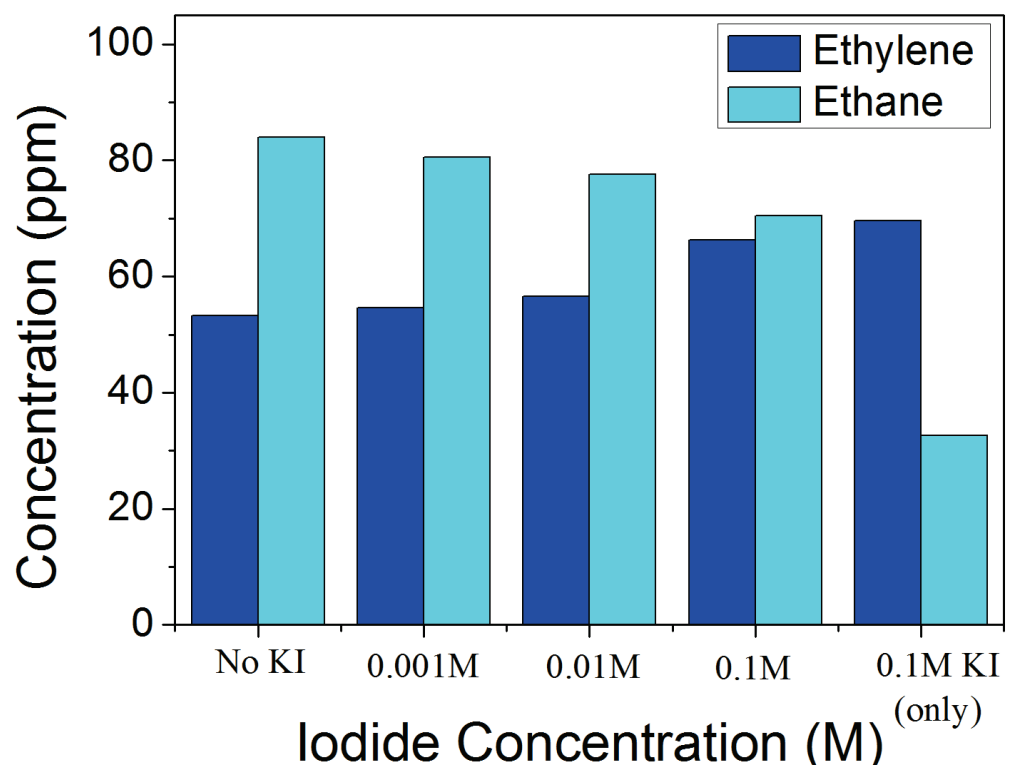

Figure 3: Steady state concentration of ethylene and ethane in the reactor at an applied current density of $50 \mathrm{~mA} / \mathrm{cm}^{2}$. The iodide concentration was varied, while the concentration of $\mathrm{KHCO}_{3}$ was fixed at $0.1 \mathrm{M} \mathrm{KHCO}_{3}$. (Except in the last experiment, which was performed in only $\mathrm{KI}$ as electrolyte. The $\mathrm{CO}_{2}$ flow rate was fixed at $50 \mathrm{ml} \mathrm{min}^{-1}$ in all experiments.) 
especially in pure $\mathrm{KI}$, suggests the iodide might also prevent the adsorption $\mathrm{CO}_{2}$. The color change of the electrode surface after the experiments also suggest the formation of copper iodide, particularly when there is no applied cathodic potential.

The experiments performed at the presence of iodide suggest that the ethylene molecules might spend sufficient time in the reactor, and re-adsorb on to the electrode surface to further hydrogenate to ethylene. To explore such a mechanism, we performed experiments by changing the flow rate of $\mathrm{CO}_{2}$ which eventually will influence the residence time of ethylene in the reactor. In Figure 4a the total concentrations of hydrocarbons in the reactor is given as a function of flow rate when a constant current of $50 \mathrm{~mA} \mathrm{~cm}^{-2}$ was applied. The time needed for to reach steady state clearly increases as the flow rate of $\mathrm{CO}_{2}$ was decreased from 65 to $20 \mathrm{ml} \mathrm{min}$. Furthermore, the steady state concentration increased, as anticipated, at low flow rates. Eventually, the average time that an ethylene molecule spent in the reactor increases with the decreasing flow rate. However, as shown in Figure $4 \mathrm{~b}$, this has only a small effect on the amount of ethane that is formed. This is consistent with the fact that no ethane was reported even in batch reactors, where ethylene concentration in the reactor might be very high at high conversions. [18]

These results than can be discussed based on the molecular scale or mesoscopic scale. We propose a mechanism that has been introduced very recently for electrocatalytic reactions by Behm et al.[21] According to this mechanism, stable intermediates, formed during an electrochemical oxidation or a reduction, can desorb,

a)

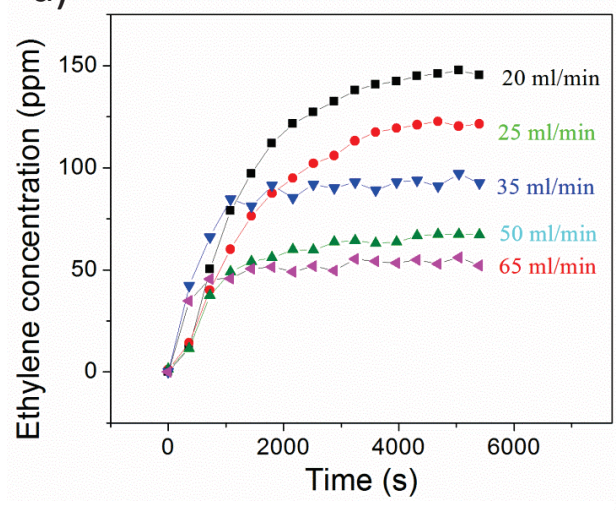

b)

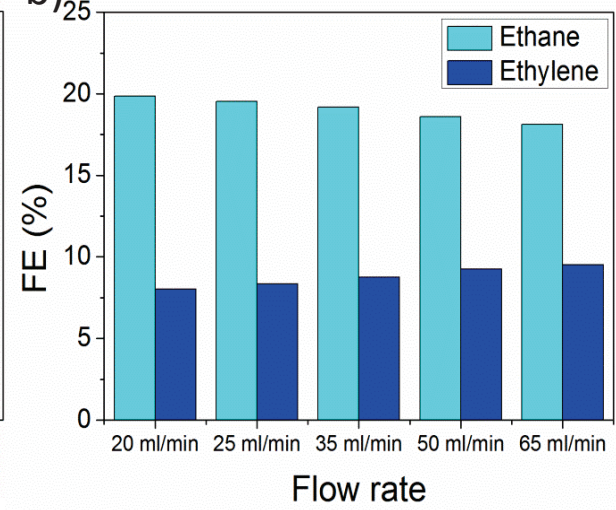

Figure 4: a) Total concentration and b) FE of ethylene and ethane in the reactor as a function of flow rate of $\mathrm{CO}_{2}$ in $0.1 \mathrm{M} \mathrm{KHCO}_{3}$ at an applied current density of $50 \mathrm{~mA} \mathrm{~cm}^{-2}$. 


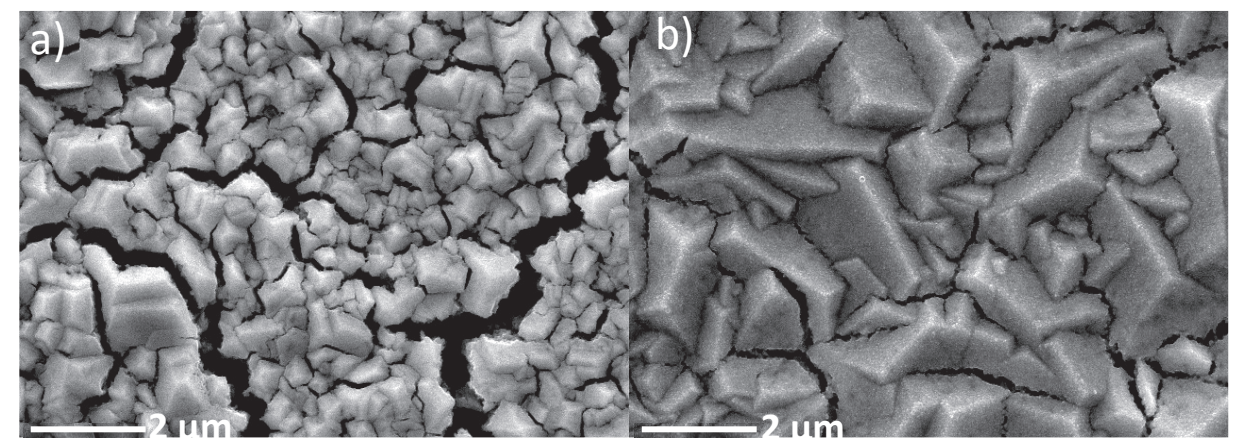

Figure 5: Low magnification SEM images of a) low and b) high roughness copper surfaces prepared by starting with thin and thick oxide layers respectively.

and re-adsorb to further react to a stable intermediate or final products. Thus, by changing the catalyst loading or flow rate of the liquid, the relative amount of the stable intermediates desorbed from surface can be changed. In methanol oxidation, the amount of incomplete oxidation products, formaldehyde and formic acid, was shown to be influenced dramatically. Formaldehyde, as a stable intermediate, was produced predominantly at low catalyst loadings whereas the complete oxidation to $\mathrm{CO}_{2}$ was observed at high catalyst loadings. [22] Similarly, in the oxygen reduction reaction, the hydrogen peroxide yield was increased exceptionally relative to the final product, water, by decreasing the density of Pt disks on glassy carbon which was prepared by lithographic methods.[21] Similar trends were also observed in CO and ethanol oxidation.[23]

For copper nanoparticles, concurrently with an initial parent oxide thickness, the roughness of the electrodes was increased as emphasized in Chapter 3. SEM images of the two different $\mathrm{Cu}_{2} \mathrm{O}$ samples $\left(5\right.$ and $13 \mathrm{C} \mathrm{cm}^{-2}$ ) after the electrochemical reduction of the thin films are shown in Figures $5 \mathrm{a}$ and $5 \mathrm{~b}$, respectively. The morphology of the thinner [110] oriented films is not well pronounced, whereas thicker films show characteristic triangular pyramid morphology. It can be seen that the increase in the initial oxide films thickness increases the coverage of the pyramids, which are again composed of aggregated copper nanoparticles. As the thickness of the initial oxide films increases, the size of the cracks between the overlapping pyramids decreases and the individual pyramids start to form continuous films. So, the parent oxide layer can be viewed as catalyst loading which affects the number density of the 74 
a)

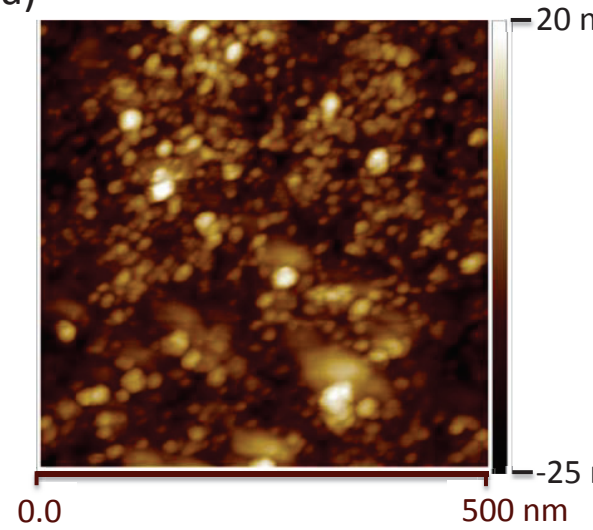

b)

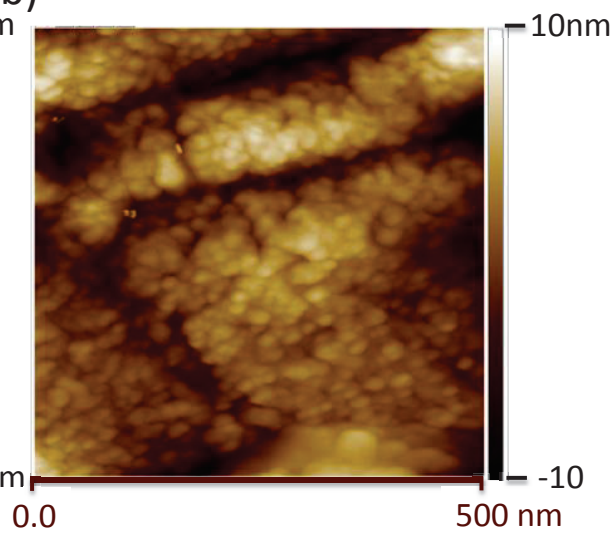

Figure 6: AFM images of a) low and b) high roughness copper surfaces prepared by starting with thin and thick oxide layers respectively.

nanoparticles and correspondingly the distance between them. This is also evident by the atomic force microcopy (AFM) image of the thin and thick samples (Figure 6a and $6 \mathrm{~b})$. So the trends that is observed by the variation of thickness (Chapter 3 ), is very similar to the "desorption-re-adsorption-reaction" concept described above. As the roughness and corresponding catalyst loading was increased, the full reduction of $\mathrm{CO}_{2}$ to ethane was observed whereas the low catalyst loadings predominantly forms ethylene as a stable intermediate. Ethylene re-adsorbs on the surface of the electrode before it leaves the diffusion layer and is reduced further to ethane. The increase in readsorption probability of ethylene as the roughness of the electrodes was increased is a possible explanation for the formation of ethane on very rough surfaces. This proposed mechanism is consistent with the experiments above however further experiments in liquid flow cells can be performed to further validate this hypothesis.

Apart from this, another explanation might be the adsorption strength and corresponding catalytic performance of roughened copper surfaces. Even though ethylene hydrogenation has little industrial interest, fundamentally it has been studied intensively, especially in heterogeneous catalysis, as a model reaction for hydrogenation reactions. Adsorption of ethylene on to metal surfaces can be considered as both geometrically and electronically. The two modes of adsorption, $\pi$ ethylene and di-sigma ethylene are considered as physisorption and chemisorption respectively.[24] Therefore, di-sigma bounded ethylene is usually considered as suitable for catalytic activation. Geometrical effects are very useful especially when there are multiple carbon bonds as in the case of $\mathrm{CO}$ coupling proposed for the 
formation of ethylene.[25] The energetics of the di-sigma bounded ethylene molecule will strictly depend on the distance between two metal atoms, since this would affect the angle $(\beta)$ between the metal--carbon bond (shown in Figure 7). An angle of 109.5, for example, would be very close to tetrahedral geometry and thus forming a fairly strong and stable bond. Large deviations from this angle would bring ring strain which will at the end destabilize and would not activate ethylene catalytically.[26] There will be an optimum angle where a maximum reaction rate will be observed. Therefore, one would expect this reaction to be structure sensitive.

Ethylene hydrogenation was reported to be structure sensitive on nickel surfaces, whereas on platinum and rhodium single crystals, foils or supported catalyst, the reaction proceeds with similar rates implying other dominant factors.[27] The activity of a heterogeneous copper catalyst was very low compared to rhodum or platinum, and the activity of Ni-Cu alloys was reported to be decreased dramatically when the surface of the catalyst was enriched by copper.[28] However, this might be due to the low amount of adsorbed hydrogen on copper surfaces rather than the adsorption strength of ethylene.[29, 30] Hori et al. attributed the formation of ethane to the abundance of adsorbed hydrogen on rough copper surfaces prepared by oxidation and followed by reduction. However, no experiments were designed to validate this hypothesis so far.[6] The adsorption of ethylene to low index copper surfaces is weak and reversible in a $\pi$ bounded state,[31,32] whereas di- $\sigma$-bounded ethylene was observed on high index copper surfaces.[33] Additionally, the adsorption strength of ethylene was found to be higher on roughened copper surfaces, which is attributed to the better stabilization of defects, steps etc. So we don't rule out the possibility of increased ethylene adsorption on our rough copper surfaces. This would also explain the increased amount of ethane formation as the surface of the electrode gets rougher. However, it is important to note that the mechanism of ethylene hydrogenation, or mechanisms in general, differ in heterogeneous catalysis and electrocatalysis.[20] Nevertheless, the adsorption strength or geometric stabilization always helps for the interpretation for both catalytic fields. The
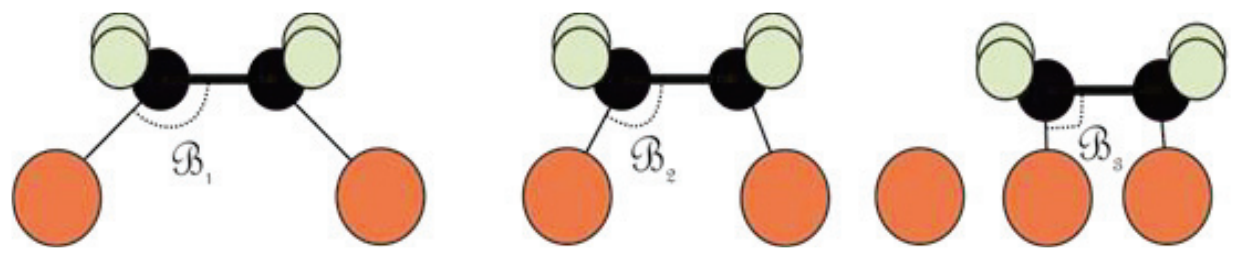

Figure 7 : Di-sigma bounded ethylene to metal crystal with different bond lengths 
electrochemical hydrogenation of ethylene unfortunately hasn't been performed on copper surfaces to the best of our knowledge, while many studies on other metals, especially on platinum, exist. Even though we showed that ethylene hydrogenation is feasible on even on smooth copper surfaces by OLEMS studies, it is important to note the technique is very sensitive and the activity of the copper might be very low.

In summary, for the first time we showed ethane is formed on copper surface by ethylene hydrogenation. The amount of ethylene produced can be increased by iodide addition which prevents ethylene re-adsorption, however this reduced the overall hydrocarbon formation as well. Surfaces with higher roughness are composed of nearly continuous nanoparticulate films with a relatively high number censity of nanoparticles. The formation of ethane on copper nanoparticles in $\mathrm{CO}_{2}$ reduction conditions can likely be attributed to the re-adsorption of ethylene, before it leaves the diffusion layer. Due to the high number density of the nanoparticles at high catalyst loadings, hydrogenation of ethylene can become significant.

\subsection{References}

1. Whipple, D.T. and P.J. Kenis, Prospects of $\mathrm{CO}_{2}$ utilization via direct heterogeneous electrochemical reduction. The Journal of Physical Chemistry Letters, 2010. 1(24): p. 3451-3458.

2. Kuhl, K.P., et al., New insights into the electrochemical reduction of carbon dioxide on metallic copper surfaces. Energy \& Environmental Science, 2012. 5(5): p. 7050-7059.

3. Ren, D., et al., Selective Electrochemical Reduction of Carbon Dioxide to Ethylene and Ethanol on Copper (I) Oxide Catalysts. ACS Catalysis, 2015. 5(5): p. 2814-2821.

4. Sen, S., D. Liu, and G.T.R. Palmore, Electrochemical reduction of $\mathrm{CO}_{2}$ at copper nanofoams. ACS Catalysis, 2014. 4(9): p. 3091-3095.

5. $\mathrm{Li}, \mathrm{C} . \mathrm{W}$. and M.W. Kanan, $\mathrm{CO}_{2}$ reduction at low overpotential on $\mathrm{Cu}$ electrodes resulting from the reduction of thick $\mathrm{Cu}_{2} \mathrm{O}$ films. Journal of the American Chemical Society, 2012. 134(17): p. 7231-7234.

6. Hori, Y., et al., Electrochemical reduction of $\mathrm{CO}$ at a copper electrode. The Journal of Physical Chemistry B, 1997. 101(36): p. 7075-7081.

7. Lu, Q.J. Rosen, and F. Jiao, Nanostructured Metallic Electrocatalysts for Carbon Dioxide Reduction. ChemCatChem, 2015. 7(1): p. 38-47.

8. Kas, R, et al., Electrochemical $\mathrm{CO}_{2}$ reduction on $\mathrm{Cu}_{2} \mathrm{O}$-derived copper nanoparticles: controlling the catalytic selectivity of hydrocarbons. Physical Chemistry Chemical Physics, 2014. 16(24): p. 12194-12201. 
9. Gonçalves, M., et al., Selective electrochemical conversion of $\mathrm{CO}_{2}$ to $\mathrm{C2}$ hydrocarbons. Energy Conversion and Management, 2010. 51(1): p. 30-32.

10. Goncalves, M., et al., Electrochemical conversion of $\mathrm{CO}_{2}$ to $\mathrm{C} 2$ hydrocarbons using different ex situ copper electrodeposits. Electrochimica Acta, 2013. 102: p. 388-392.

11. Hori, Y., et al., Selective formation of C2 compounds from electrochemical reduction of $\mathrm{CO}_{2}$ at a series of copper single crystal electrodes. The Journal of Physical Chemistry B, 2002. 106(1): p. 15-17.

12. Hori, Y., Electrochemical $\mathrm{CO}_{2}$ reduction on metal electrodes, in Modern aspects of electrochemistry 2008, Springer. p. 89-189.

13. Gärtner, C.A., A.C. van Veen, and J.A. Lercher, Oxidative Dehydrogenation of Ethane: Common Principles and Mechanistic Aspects. ChemCatChem, 2013. 5(11): p. 3196-3217.

14. Schouten, K.J.P., et al., Two pathways for the formation of ethylene in CO reduction on single-crystal copper electrodes. Journal of the American Chemical Society, 2012. 134(24): p. 9864-9867.

15. Li, C.W., J. Ciston, and M.W. Kanan, Electroreduction of carbon monoxide to liquid fuel on oxide-derived nanocrystalline copper. Nature, 2014. 508(7497): p. 504-507.

16. Montoya, J.H., A.A. Peterson, and J.K. Nørskov, Insights into C-C Coupling in $\mathrm{CO}_{2}$ Electroreduction on Copper Electrodes. ChemCatChem, 2013. 5(3): p. 737-742.

17. Schouten, K., et al., A new mechanism for the selectivity to C1 and C2 species in the electrochemical reduction of carbon dioxide on copper electrodes. Chemical Science, 2011. 2(10): p. 1902-1909.

18. Protopopoff, E. and P. Marcus, Potential-pH diagrams for hydroxyl and hydrogen adsorbed on a copper surface. Electrochimica Acta, 2005. 51(3): p. 408-417.

19. Roduner, E., Understanding catalysis. Chemical Society Reviews, 2014. 43(24): p. 8226-8239.

20. Wieckowski, A, et al., A comparison of gas-phase and electrochemical hydrogenation of ethylene at platinum surfaces. Journal of the American Chemical Society, 1985. 107(21): p. 5910-5920.

21. Seidel, Y., et al., Mesoscopic mass transport effects in electrocatalytic processes. Faraday discussions, 2009. 140: p. 167-184.

22. Seidel, Y., et al., Transport effects in the electrooxidation of methanol studied on nanostructured Pt/glassy carbon electrodes. Langmuir, 2009. 26(5): p. 35693578 . 
23. Wang, H., Z. Jusys, and R. Behm, Ethanol electrooxidation on a carbon-supported Pt catalyst: reaction kinetics and product yields. The Journal of Physical Chemistry B, 2004. 108(50): p. 19413-19424.

24. Watwe, R.M., et al., Density functional theory studies of the adsorption of ethylene and oxygen on Pt (111) and Pt3Sn (111). Journal of Chemical Physics, 2001. 114(10): p. 4663-4668.

25. Calle-Vallejo, F. and M. Koper, Theoretical considerations on the electroreduction of $\mathrm{CO}$ to $\mathrm{C} 2$ species on $\mathrm{Cu}$ (100) electrodes. Angewandte Chemie, 2013. 125(28): p. 7423-7426.

26. Richardson, J.T., Principles of catalyst development2013: Springer.

27. Wijngaarden, R.I., et al., Industrial catalysis: optimizing catalysts and processes2008: John Wiley \& Sons.

28. Takeuchi, T., et al., Catalytic activities of copper-nickel alloys for hydrogenating reactions. Bulletin of the Chemical Society of Japan, 1962. 35(8): p. 1390-1394.

29. Anderson, J., Chemisorption and reactions on metallic films. Vol. 1. 2012: Elsevier.

30. Masel, R.I., Principles of adsorption and reaction on solid surfaces. Vol. 3. 1996: John Wiley \& Sons.

31. Linke, R, et al., Adsorption of ethene on $\mathrm{Cu}$ (111). Surface Science, 1997. 377: p. 655-658.

32. Nyberg, C., et al., Vibrational excitations and structure of $\mathrm{C} 2 \mathrm{H} 4$ adsorbed on $\mathrm{Cu}(100)$. Chemical Physics Letters, 1982. 87(1): p. 87-91.

33. Kravchuk, T., et al., Ethene Adsorption and Decomposition on the $\mathrm{Cu}(410)$ Surface. The Journal of Physical Chemistry C, 2009. 113(49): p. 20881-20889. 


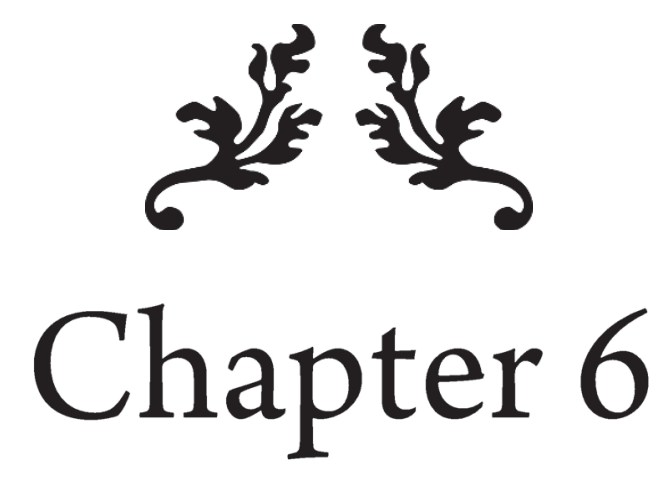

3-D porous hollow fiber electrodes for efficient and highrate electrochemical carbon dioxide reduction

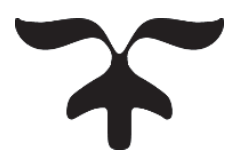




\begin{abstract}
Aqueous conversion of carbon dioxide not only requires an efficient and stable electrocatalyst, but also improved mass transport of carbon dioxide to the electrode surface as a result of limited solubility. Herein, we prepared hollow copper fibers via facile and industrially feasible spinning method and employed the fibers both as an electrode and a gas diffuser in a very simple and compact 3-D geometry. Initiating electrochemical carbon dioxide reduction on these fibers leads to faradaic efficiencies of up to $\approx 85 \%$ at overpotentials between $200 \mathrm{mV}$ and $400 \mathrm{mV}$. Moreover, we achieved more than one to two orders of magnitude enhancement in $\mathrm{CO}$ formation rate at similar potentials, when compared to copper nanoparticles or polycrystalline copper, respectively. The results of this study may inspire the development of new type of electrodes for ambient temperature and pressure electrochemical processes where one or more reactants are present in the gas phase, as e.g. in fuel cell applications.
\end{abstract}




\subsection{Introduction}

The accumulation of carbon dioxide $\left(\mathrm{CO}_{2}\right)$ in the atmosphere and its impact on climate change has already started to affect natural life.[1-3] Immediate measures must be taken to minimize carbon emissions. [4] A promising way is to convert $\mathrm{CO}_{2}$ to useful chemicals by using electricity generated by renewable energy sources.[5-7] Nevertheless, the development of an efficient and stable electrocatalyst that can reduce $\mathrm{CO}_{2}$ at high current densities, remains a challenge.[8] In recent years, researchers achieved to produce $\mathrm{CO}$ at low potentials in aqueous solutions albeit with limited current densities or using noble metals.[9-11] Reasonable current densities at low overpotentials towards $\mathrm{CO}$ were achieved by using ionic liquids. $[12,13]$ However, considering ionic liquids, several issues remain challenging such as cost, recycling, stability and electrolyzer performance in practical applications.[9, 14] Aqueous conversion of $\mathrm{CO}_{2}$ is still more attractive if high selectivity towards $\mathrm{CO}_{2}$ over water splitting can be achieved at low overpotentials and high current densities.

Copper electrodes are well known for producing hydrocarbons from $\mathrm{CO}_{2}$ with variable onset potentials ( $-0.5 \mathrm{~V}$ to $-0.7 \mathrm{~V}$ vs $\mathrm{RHE})$ depending on the preparation method.[15-17] Generally, high overpotentials $(\approx 0.8-1 \mathrm{~V})$ are necessary to obtain reasonable faradaic efficiency (FE). Although less expensive than other $\mathrm{CO}$ evolving catalysts such as e.g. silver and gold, poor activity, selectivity and stability towards CO and formic acid have been reported for polycrystalline copper. $[18,19]$ Recently, Li et al. reported production of $\mathrm{CO}$ and formic acid with reasonable $\mathrm{FE}$ at low overpotentials on copper nanoparticles, when formed by electrochemical reduction of cuprous oxides.[20] At a potential of $-0.5 \mathrm{~V}$ vs. RHE, a copper surface covered with nanoparticles delivered a $\mathrm{CO}_{2}$ reduction current density of $2.1 \mathrm{~mA} / \mathrm{cm}^{2}$, with a $\mathrm{FE}$ of $35 \%$ and $32 \%$ for $\mathrm{CO}$ and formic acid respectively. Even though such a selectivity can be considered as low, this was the first publication showing $\mathrm{CO}$ and formic acid formation is feasible over copper electrodes. Additionally, production of energy dense products such as ethylene, ethanol and methane might require selective conversion to $\mathrm{CO}$ first, since $\mathrm{CO}$ is a common intermediate for nearly all hydrocarbons and oxygenates.[21,22]

Inorganic hollow fibers are of potential significance for solid oxide fuel cells (SOFC) due to their high surface area to volume ratio, higher power outputs and lower fabrication costs[23-25] but utilization in room temperature solution based electrochemistry is quite rare. Several examples exist using nickel and carbon hollow 
fibers with dual functionality, where they served as both membrane for effluent purification and as cathode for proton and oxygen reductions, respectively.[26, 27] Here, for the first time we demonstrate that hollow fiber electrodes can be a potential candidate for low pressure and room temperature electrolysis of $\mathrm{CO}_{2}$, due to their excellent mass transport capabilities when used as gas diffuser and cathode. Not only the hydrogen evolution reaction is suppressed on these electrodes to levels not reached previously on copper surfaces, but also the overall $\mathrm{CO}_{2}$ reduction current density is unprecedentedly high.

\subsection{Results and Discussion}

The preparation of the metal hollow fibers i.e. nickel and stainless steel has been described in the literature previously. $[28,29]$ The preparation of Cu hollow fiber, on the other hand, has not been reported to the best of our knowledge. We adapted a similar method and prepared $\mathrm{Cu}$ hollow fibers by spinning a polymer solution containing copper powder. Compact, porous and hollow copper oxide fibers were obtained after sintering. Hydrogenation of these precursor fibers at elevated temperatures was applied to obtain metallic copper fibers (See Chapter 2 for details). The XRD diagram of the precursor copper powder, calcined and hydrogenated fibers are given in Figure 1. Calcination of copper for sintering and removing organics generated a thick oxide layer on the surface $(\mathrm{CuO})$. The subsequent hydrogenation of calcined fibers apparently lead to formation of metallic fibers. Typical scanning electron microscope (SEM) images of the Cu hollow fibers are shown in Figure 2. The low and higher magnification images of the external surface of the fibers show that the

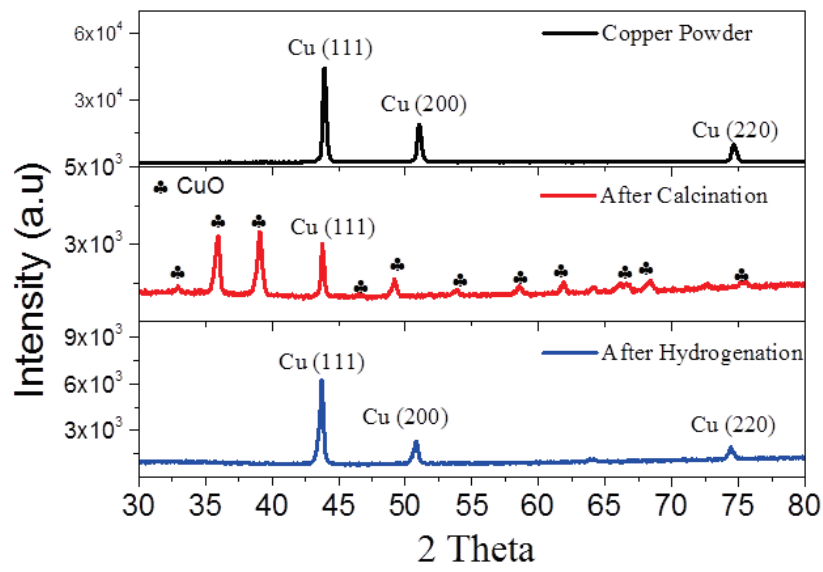

Figure 1: XRD diagram of precursor copper powder, $\mathrm{Cu}$ hollow fiber after calcination at $600^{\circ} \mathrm{C}$ and the copper fiber after hydrogenation. 
fiber is composed of aggregated copper particles forming an interconnected 3-D porous structure (Figure $2 \mathrm{a}$ and $2 \mathrm{~b}$ ). The cross-sectional images of the deliberately broken fibers exhibit fingerlike voids perpendicular to the surface which are terminated by a $10-15 \mu \mathrm{m}$ thick sponge- like porous outer layer (Figures $2 \mathrm{c}$ and $2 \mathrm{~d}$ ). Cu hollow fibers have outer and inner diameters ranging from $1.55 \pm 0.1 \mathrm{~mm}$ to $1.3 \pm 0.05 \mathrm{~mm}$ respectively (Figure $2 \mathrm{e}$ ). $\mathrm{CO}_{2}$ was pushed from the inside out of the fiber, creating an overpressure around $1.70 \pm 0.1$ bars due to the resistance of the porous structure. Gas bubbles emerging out of the fiber can be clearly seen in Figure $2 \mathrm{f}$. The pressure is considered to spread out the finger-like holes without resistance and to drop across the porous outer layer to 1.05 bar. When a potential is applied, electrochemical reduction likely takes place both at the interface of $\mathrm{CO}_{2}(\mathrm{~g})$ and water $(\mathrm{l})$ in contact with copper (s), as well as near the electrode surface with dissolved $\mathrm{CO}_{2}$.

For monitoring the electrochemical activity of the fibers, linear sweep voltammetry experiments were performed in $\mathrm{CO}_{2}$ saturated electrolyte, while $\mathrm{Ar}$ or

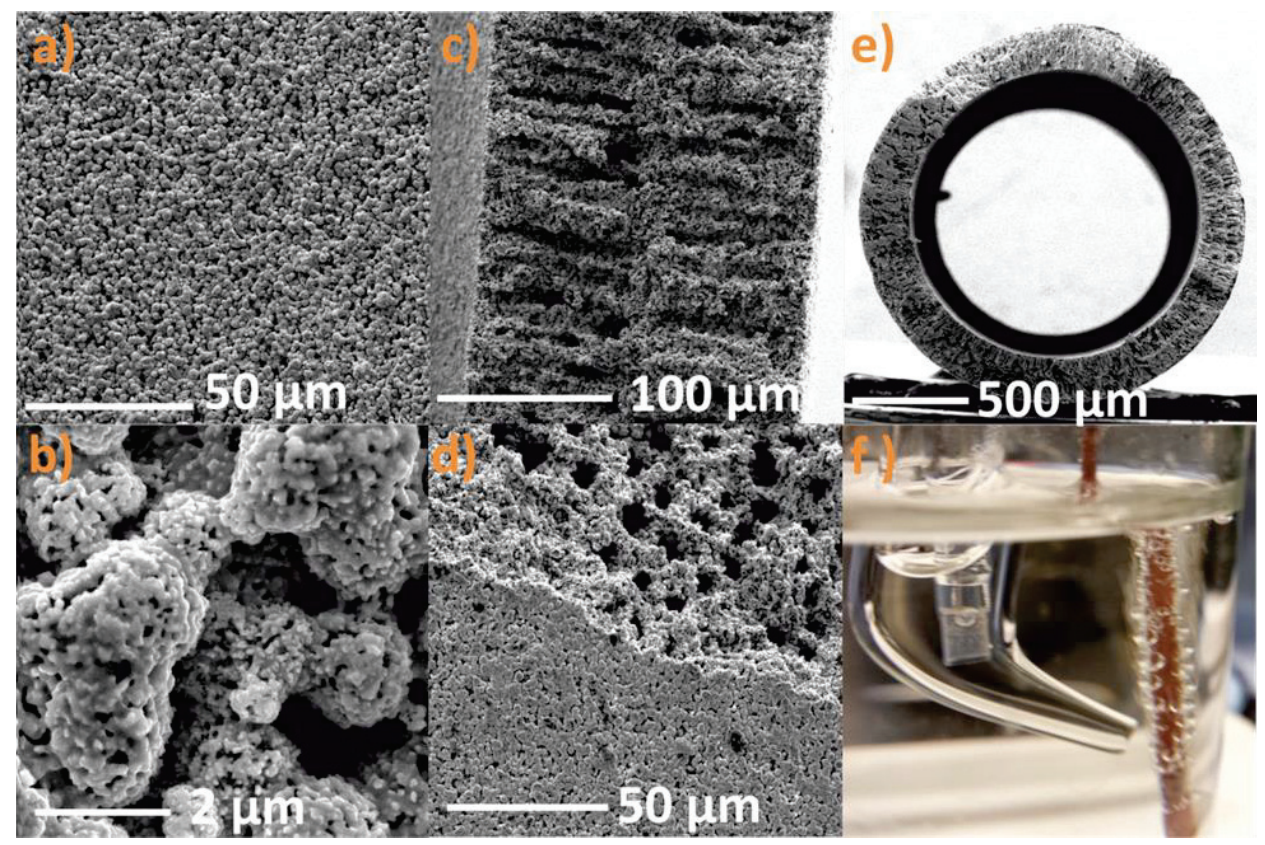

Figure 2: Physical Characterization of Cu hollow fibers. a) Low and b) High magnification SEM images of the outer surface of the $\mathrm{Cu}$ hollow fiber. c) Side view and d) Top view of the crosssectional image of intentionally broken $\mathrm{Cu}$ hollow fiber. e) Image of $\mathrm{Cu}$ hollow fiber taken by the electron microscope, and f) Cu hollow fiber employed as an electrode $\left(20 \mathrm{ml} \mathrm{min}^{-1}\right.$ gas flow and no applied potential) 
$\mathrm{CO}_{2}$ were purged through the fibers (Figure 3a). The current densities recorded during Ar purge are mostly due to hydrogen evolution, which has an onset potential of around $-0.25 \mathrm{~V}$ vs. RHE. Bubbling $\mathrm{CO}_{2}$ through the fiber leads to ca. two-fold increase in cathodic current densities at potentials between -0.2 and $-0.4 \mathrm{~V}$ vs. RHE. On the contrary, on both smooth or rough copper surfaces lower current densities were reported under $\mathrm{CO}_{2}$ atmosphere as compared to $\mathrm{Ar}$ atmosphere.[30, 31] This was attributed to co-adsorption of $\mathrm{CO}$, weakening the binding energy of hydrogen to the electrode surface and retarding the hydrogen evolution reaction.[32] In other words, most of the cathodic current was considered to be a result of hydrogen production at low potentials, even in the presence of $\mathrm{CO}_{2}$ or $\mathrm{CO}$. So the high cathodic currents achieved in the presence of $\mathrm{CO}_{2}$ on $\mathrm{Cu}$ hollow fiber in this study is already an indication of distinctive activity towards $\mathrm{CO}_{2}$ reduction.
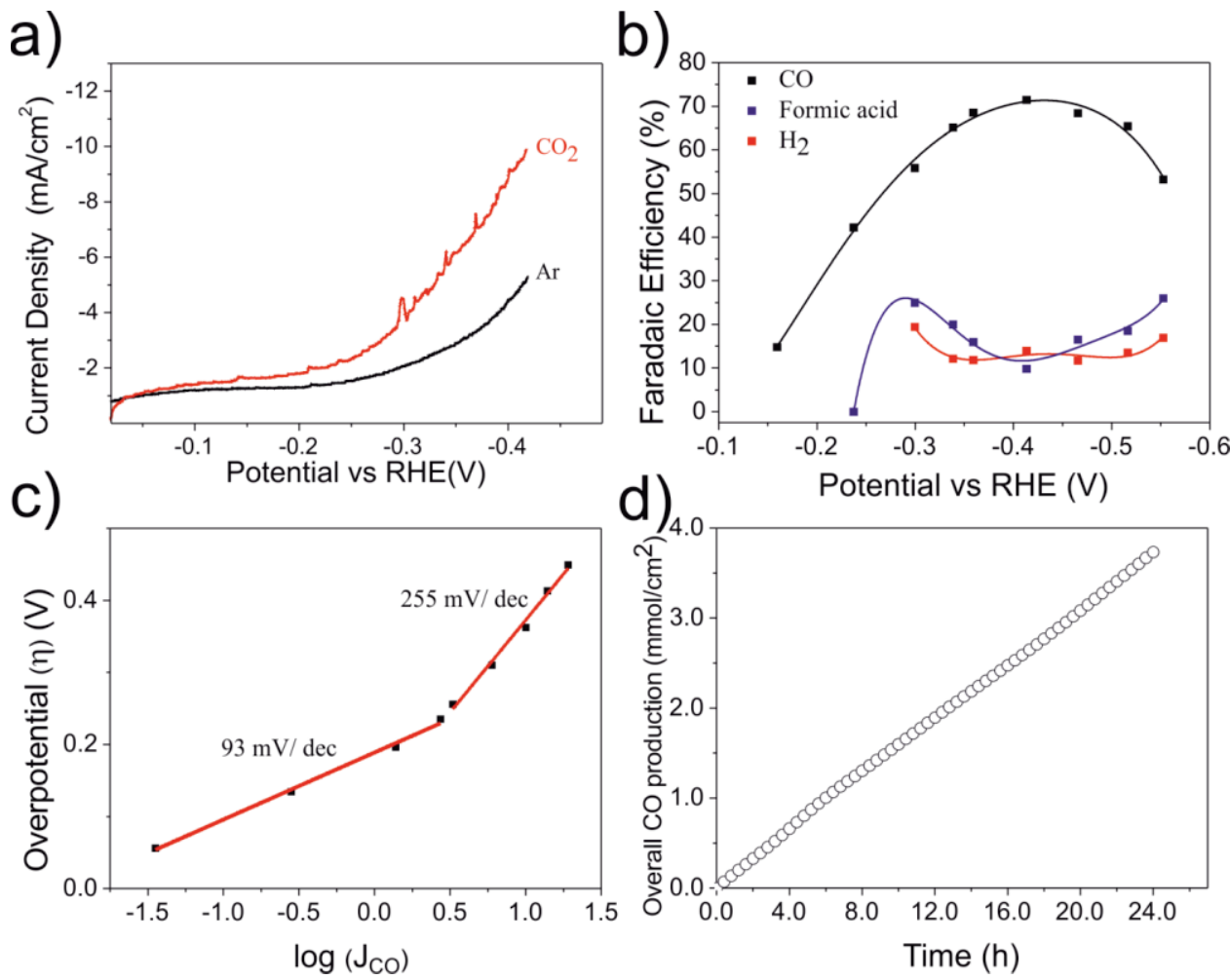

Figure 3: Electrocatalytic Performance of $\mathrm{Cu}$ hollow fibers. a) Linear polarization curves for $\mathrm{Cu}$ hollow fiber under $\mathrm{CO}_{2}$ and $\mathrm{Ar}$ atmosphere in $0.3 \mathrm{M}$ of $\mathrm{KHCO}_{3}$. (Scan rate $50 \mathrm{mv} \mathrm{s}{ }^{-1}$ ) b) FE of $\mathrm{CO}$, Formic acid and $\mathrm{H}_{2}$ at different potentials. c) Overpotential vs. partial current density of $\mathrm{CO}$ for $\mathrm{Cu}$ hollow fiber. $\mathrm{d}$ ) Total production of $\mathrm{CO}$ at an applied potential of $-0.4 \mathrm{~V}$ for 24 hours of continuous experiment (Flow rate of $\mathrm{CO}_{2}: 20 \mathrm{ml} \mathrm{min}^{-1}$ ) 
To confirm the catalytic activity, the FE of the major products was measured by varying the applied potential between $-0.15 \mathrm{~V}$ and $-0.55 \mathrm{~V}$ vs. RHE (Figure $3 \mathrm{~b}$ ). The onset of $\mathrm{CO}$ formation is located at $-0.15 \mathrm{~V}$ vs RHE, implying an overpotential of just $\approx 40 \mathrm{mV}$ above the equilibrium potential $(-0.11 \mathrm{~V}$ vs. RHE). The total FE efficiency of the $\mathrm{CO}_{2}$ reduction products adds up to $\approx 85 \%$ at potentials between $-0.3 \mathrm{~V}$ and $-0.5 \mathrm{~V}$ vs. RHE. Specifically, a peak FE of $\approx 72 \%$ was obtained for $\mathrm{CO}$ at a potential of $-0.4 \mathrm{~V}$ vs. RHE, whereas the maximum FE for $\mathrm{CO}$ on polycrystalline copper and copper nanoparticles has been reported to be around $20 \%(-0.8 \mathrm{Vvs}$. RHE) and $45 \%$ (J $\mathrm{Co} \approx 300$ $\left.\mu \mathrm{A} / \mathrm{cm}^{2}\right)$, respectively. $[19,20]$ The decrease in FE of CO at more negative potentials $(<-0.5 \mathrm{~V})$ implies CO formation is now most likely limited by desorption. Additionally, ethylene was detected at these potentials (Table 1), which is formed by coupling of two $\mathrm{CO}$ molecules.[33] On that account, the formation of hydrocarbons still requires relatively large overpotentials on $\mathrm{Cu}$ hollow fiber, and direct $\mathrm{CO}_{2}$ reduction to energy dense products remains a challenge. Contrary to polycrystalline copper and copper nanoparticles, formation of formic acid is relatively suppressed, which is consistent with literature[34-36] and electrokinetic data (a Tafel plot), displayed in Figure 3-c. The slope of $93 \mathrm{mV} / \mathrm{dec}$ associated with the lower potential region, suggests a mechanism in which initial electron transfer to $\mathrm{CO}_{2}$ is rate determining.[19] More importantly, at more negative potentials, an apparent change in Tafel slope is observed, which suggests a change in rate determining step or mechanism. By also considering the fact that higher pressures can induce $\mathrm{CO}$ production on copper nanoparticles [36, 37] the rate of $\mathrm{CO}$ production compared to formic acid, on this potential range, might be more sensitive to $\mathrm{CO}_{2}$ concentration as has been suggested for $\mathrm{CO}_{2}$ reduction in media of low proton availability.[35] Likewise, studies on various metal electrodes in water showed a higher order dependence on $\mathrm{CO}_{2}$ pressure in a second Tafel region.[34] Still, $\mathrm{CO}$ production as a function of $\mathrm{CO}_{2}$ concentration in the solution requires further investigation.

To test the stability of the $\mathrm{Cu}$ hollow fibers, 24 hours of continuous electrolysis was performed at an applied potential of -0.4 vs. RHE (Figure $3 d$ ). After a $\approx 10 \%$ drop in activity in the first 7 hours, noticeable from the slight curvature of the plot in Figure $3 \mathrm{~d}$, stable performance was achieved in the next 17 hours of experiment. SEM images of the electrode after electrolysis showed no apparent difference in the morphology of the Cu hollow fiber (not shown here). The activity of polycrystalline $\mathrm{Cu}$ is well known to degrade very quickly within an hour, unless very high purity electrolytes and electrodes are employed.[38] Cu NPs on the other hand exhibited quite stable performance when thick oxide layers are used as copper precursor.[20] However, it is important to note that these studies usually employ ultra-high purity copper plates 
Table 1: Summary of the faradaic efficiencies (FE) as a function of applied potential.

\begin{tabular}{|c|c|c|c|c|c|c|}
\hline \multirow{2}{*}{$\begin{array}{l}\text { E vs RHE } \\
\text { (V) }\end{array}$} & \multirow{2}{*}{$\begin{array}{c}\mathrm{J}_{\text {total }} \\
\left(\mathrm{mA} / \mathrm{cm}^{2}\right)\end{array}$} & \multicolumn{5}{|c|}{ Faradaic Efficiency (\%) } \\
\hline & & $\mathrm{CO}$ & Formic Acid & Ethylene & $\mathrm{H}_{2}$ & Total \\
\hline-0.16 & 0.24 & 14.8 & 0.0 & 0.0 & - & $14.8^{*}$ \\
\hline-0.24 & 0.66 & 42.2 & 0.0 & 0.0 & - & $42.2^{*}$ \\
\hline-0.30 & 2.5 & 55.9 & 25.1 & 0.0 & 19.4 & 100.4 \\
\hline-0.34 & 4.2 & 65.2 & 20.1 & 0.0 & 12.1 & 97.4 \\
\hline-0.36 & 4.8 & 68.6 & 16.2 & 0.0 & 11.8 & 96.6 \\
\hline-0.41 & 8.4 & 72.4 & 9.8 & 0.0 & 13.9 & 96.1 \\
\hline-0.47 & 14.7 & 68.5 & 16.5 & 0.1 & 11.7 & 96.8 \\
\hline-0.52 & 21.3 & 65.4 & 18.5 & 0.15 & 13.6 & 97.7 \\
\hline-0.55 & 35.7 & 53.3 & 26.2 & 0.2 & 16.9 & 96.6 \\
\hline
\end{tabular}

* Hydrogen concentrations were not measurable in these low potentials due to relatively lower detection limits towards hydrogen. The remaining current is considered to be $\mathrm{H}_{2}$ since no formic acid is detected at these potentials.

(99.9999\%) whereas the purity of the precursor copper powders used in this study is relatively low (99\%), significantly reducing the price for commercial application.

Figures $4 \mathrm{a}$ and $4 \mathrm{~b}$ show the effect of the $\mathrm{CO}_{2}$ flow rate on overall current density and $\mathrm{FE}$ of $\mathrm{CO}$ at an applied voltage of $-0.4 \mathrm{~V}$ vs. RHE, respectively. The current density undoubtedly is proportional to the $\mathrm{CO}_{2}$ flow rate above $-0.35 \mathrm{~V}$ vs. $\mathrm{RHE}$, until a certain flow rate was reached. The change in $\mathrm{FE}$ of $\mathrm{CO}$ is consistent with the increase in current density. A maximum $\mathrm{FE}$ of $75 \%$ was recorded for $\mathrm{CO}$ at a potential of $-0.4 \mathrm{~V}$ vs. RHE at optimized flow rate which is almost twice of what has been recently reported
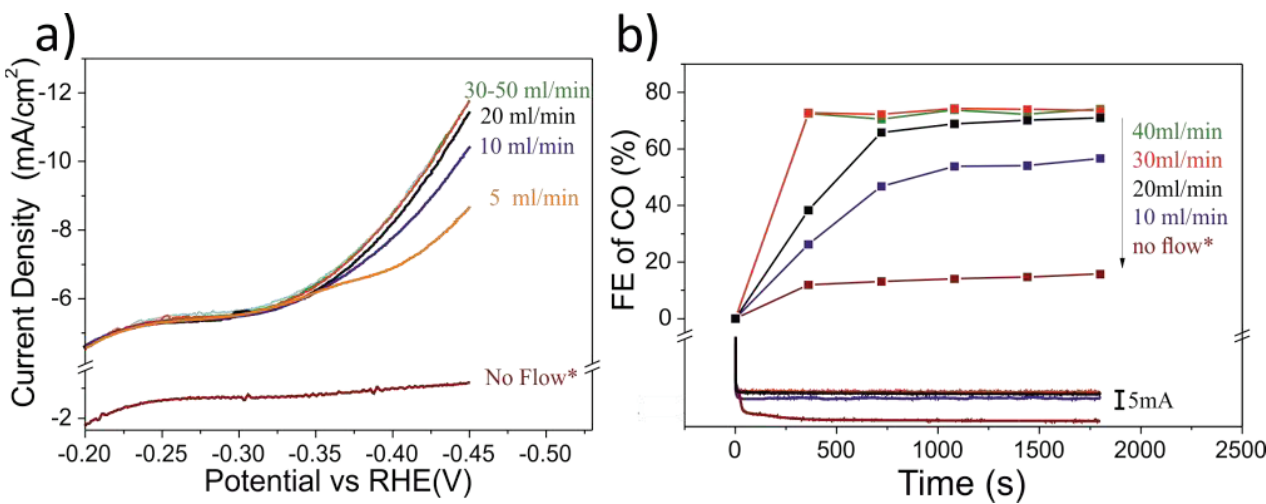

Figure 4: a) Linear Polarization curves for different flow rates of $\mathrm{CO}_{2}$. (Scan rate $50 \mathrm{mv} \mathrm{s}^{-1}$ ) b) FE of $\mathrm{CO}$ for different flow rates of $\mathrm{CO}_{2}$ (applied potential of -0.4 vs. RHE, $0.3 \mathrm{M} \mathrm{KHCO}_{3}$ ). *Experiments are performed in $\mathrm{CO}_{2}$ saturated solutions. 
for copper nanoparticles at the same potential.[20] The steady behavior above the flow rate of $30 \mathrm{ml} \mathrm{min}^{-1} \mathrm{implies}$ all the active sites are involved in converting $\mathrm{CO}_{2}$ to $\mathrm{CO}$, and the catalyst has reached its intrinsic limit. Previously, the $\mathrm{CO}_{2}$ reduction rate in aqueous conditions was shown to be proportional to the $\mathrm{CO}_{2}$ pressure on different metal electrodes, suggesting high degrees of coverage were not achieved even at pressures as high as $25 \mathrm{~atm}$. [34] On the other hand, the intermediate $\mathrm{CO}$, was considered to have a high degree of coverage during electrochemical $\mathrm{CO}_{2}$ reduction on copper electrodes, supported by spectroscopic studies.[17] By considering these facts, the remarkable performance of the $\mathrm{Cu}$ hollow fibers is attributed to both improved mass transport and better removal of $\mathrm{CO}$ from the surface, induced by a very high local concentration of $\mathrm{CO}_{2}$ near the electrode surface. Besides an improved performance, this also enables the evaluation of the intrinsic activity of the electrocatalyst especially when a competing reaction, i.e hydrogen evolution, simultaneously takes place.

An overview of the performance of different catalysts' as compared to $\mathrm{Cu}$ hollow fiber ( $\mathrm{Cu} \mathrm{HF}$ ) is shown in Figure 5. The partial current density of $\mathrm{CO}$ (Jco), representing the formation rate of $\mathrm{CO}$, is plotted against the applied potential. Besides the fact that the $\mathrm{FE}$ towards $\mathrm{CO}$ is significantly improved compared to polycrystalline $\mathrm{Cu}$ and $\mathrm{Cu}$ NPs, the partial current density for $\mathrm{CO}$ formation on $\mathrm{Cu}$ hollow fiber is exceptionally high. $\mathrm{Cu}$ hollow fibers can reduce $\mathrm{CO}_{2}$ to $\mathrm{CO}$ electrochemically at a potential of -0.4 vs. RHE, with over 15 to 400 times higher rate than $\mathrm{Cu}$ NPs and polycrystalline $\mathrm{Cu}$, respectively at a potential of -0.4 vs. RHE (see also reproducibility in Figure 6).[20] While outcompeting the currently best performing copper based

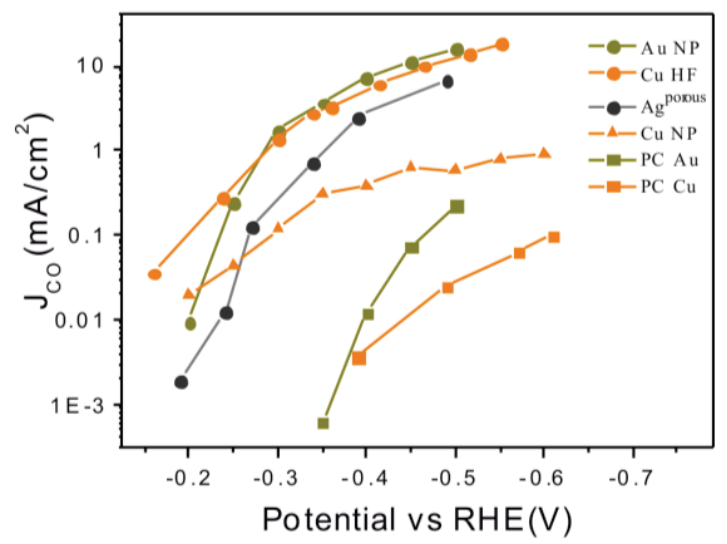

Figure 5: Overview of different catalysts' performance at different potentials with a plot of partial current density of $\mathrm{CO}$ at different potentials. Literature data are derived from the references ${ }^{911,20}$. 

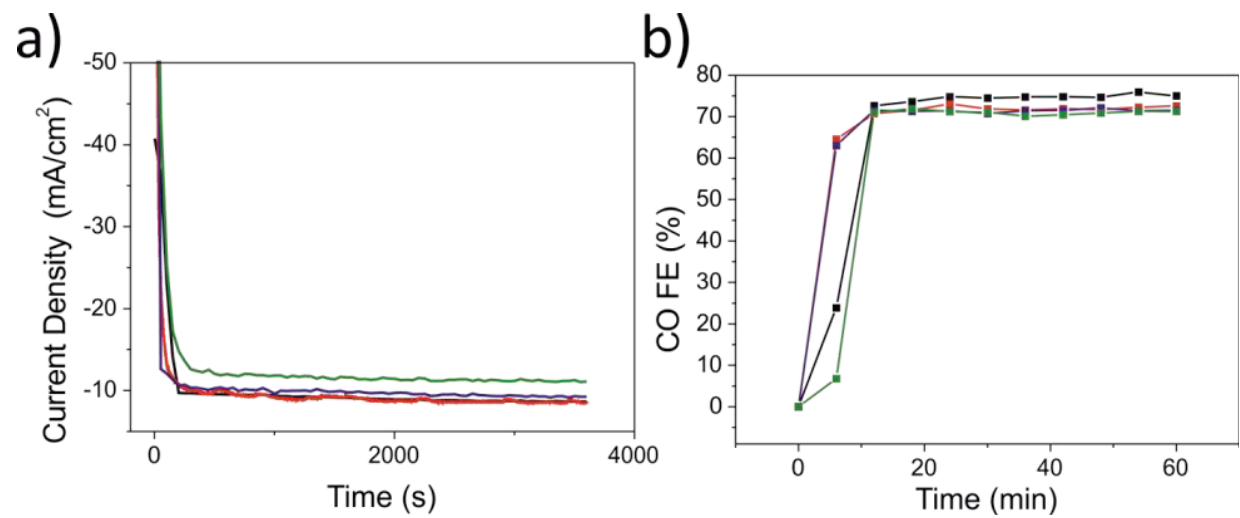

Figure 6: Reproducibility tests with different fibers at a potential of $-0.4 \mathrm{~V}$ vs RHE. a) Chronoamperometry curves b) $\mathrm{FE}$ vs time for different fibers (Flow rate of $\mathrm{CO}_{2}: 20 \mathrm{ml} \mathrm{min}^{-1}$ )

electrodes, $\mathrm{Cu}$ hollow fibers also show comparable activities at low potentials $(-0.2 \mathrm{~V}$ to $-0.6 \mathrm{~V}$ vs. RHE) to that of noble metal catalysts evaluated in aqueous solutions (Au NPs[11], Nanoporous Ag[9]). It should be recalled that noble metal electrodes benefit from a high overpotential for hydrogen evolution, while $\mathrm{Cu}$ hollow fibers perform so well on the basis of the improved mass transfer of $\mathrm{CO}_{2}$.

In addition to the comparison in Figure 5, a beneficial comparison would be on the basis of the performance of gas diffusion electrodes (GDE), where the reaction also takes place at gas-liquid-solid interfaces. Unfortunately, most of the studies use high overpotentials $(>1 \mathrm{~V})$ to evaluate hydrocarbon formation on Cu-GDE. [39, 40] In general, much higher currents densities $\left(0.1-1 \mathrm{~A} / \mathrm{cm}^{2}\right)$, albeit at high potentials, are reported on GDE which can be attributed to the high electrochemically active surface area of the electrodes.[8] The thickness of the carbon supported catalyst layers used in GDEs are typically in the range from 5-50 $\mu \mathrm{m}$ [41]. Additional electrodeposition experiments were performed on $\mathrm{Cu}$ hollow fibers to determine the reactive zones of the electrode. Nickel deposition was performed from the solutions of nickel acetate $\left(50 \mathrm{mM} \mathrm{Ni}\left(\mathrm{NO}_{3}\right)_{2}, 5 \mathrm{~mA} \mathrm{~cm}^{-2}\right.$ for $\left.900 \mathrm{~s}\right)$ with Ar purge through the fiber $\left(20 \mathrm{ml} \mathrm{min}^{-1}\right)$. The SEM images in Figure 7 showed that the Nickel deposition takes place mostly to outer surface. Energy dispersive X-ray analysis (EDX) showed that the penetration depth of Nickel through the fiber is around 15-20 $\mu \mathrm{m}$ which indicates the thickness of the electrode utilized during the $\mathrm{CO}_{2}$ reduction. This thickness is comparable to oxide films used to prepare rough electrodes or electrodeposited 3-D porous structures employed as electrodes.[42] Therefore, it is reasonable to make such a comparison given in Figure 5 by normalizing the current to the geometrical area of the fiber. In 90 


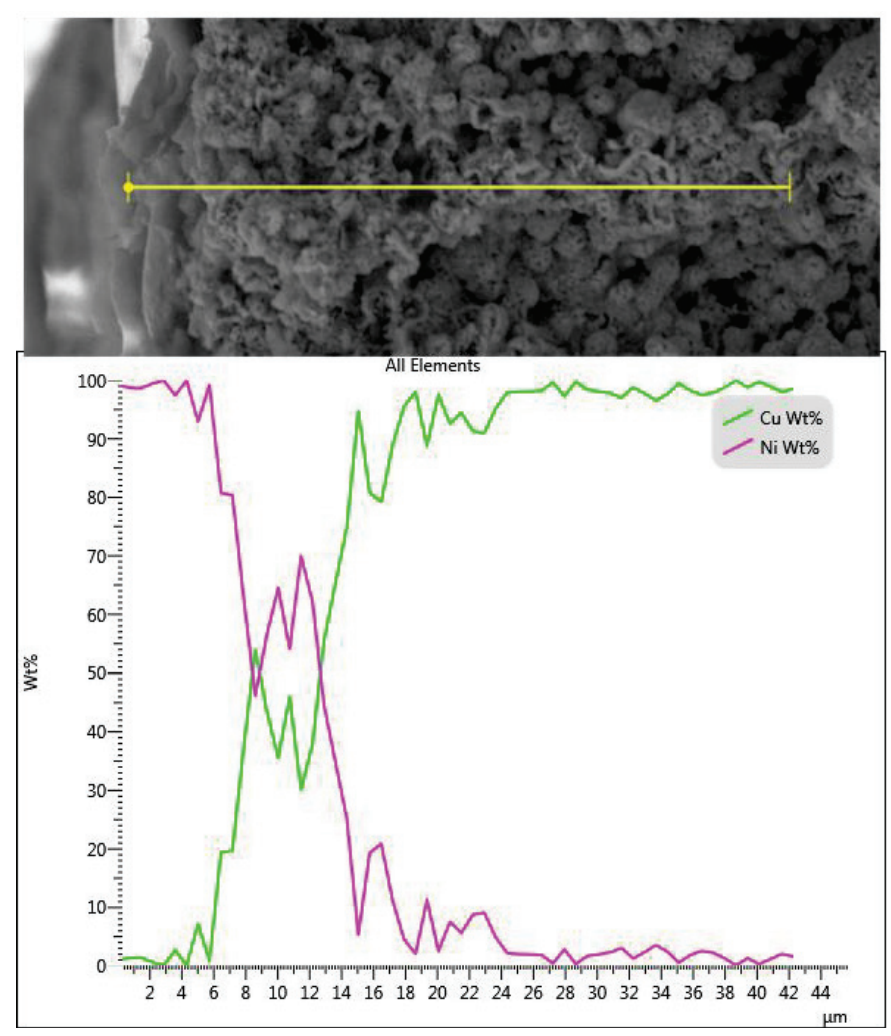

Figure 7: Line scan profiles of electrodeposited Nickel on copper hollow fibers during $20 \mathrm{ml} \mathrm{min}^{-1}$ argon purge, as determined from EDX analysis. The noisy character of the line scan is due to porous nature of the $\mathrm{Cu}$ hollow fiber.

addition, it is a common practice to use the projected area of the 3-D electrode, or so called apparent area, in conventional GDEs to report current densities. [8, 43]

GDEs played an important role in fundamental electrocatalysis, however their mass production delayed due to economic and technical issues.[41] The mature drywet spinning process allows mass production of organic hollow fibers that are already commercially available. [44] Preparation of hollow metal fibers with diameters in the range of $100-500 \mu \mathrm{m}$, on the other hand, was developed recently which adapts a very similar method, implying a great potential of large scale production. $[45,46]$ Metal hollow fibers might provide cost effective, very simple and compact diffusion media for GDE's. Furthermore, we believe there is plenty of room to increase the production rate by considering the controllability of the internal and external structure of the hollow fibers. $[25,47]$ The thickness of the active catalyst layer can be tuned by changing 3-D 
geometry, porosity and/or precursor particle size, to further optimize the production rate.

In summary, the results reported in this article highlight a new area to explore for the development of robust electrodes that can efficiently catalyze conversion of $\mathrm{CO}_{2}$ at high rates in aqueous media. Employing a simple, compact $\mathrm{Cu}$ hollow fiber as both gas diffuser and an electrode, leads to very high $\mathrm{CO}$ production rates which are comparable to what has been achieved by using noble metals. In general, hollow fibers provide new possibilities to design practically relevant electrodes and electrochemical reactors where one or more reactants are present in the gas phase.

\subsection{References}

1. Buitenwerf, R, L. Rose, and S.I. Higgins, Three decades of multi-dimensional change in global leaf phenology. Nature Clim. Change, 2015. 5(4): p. 364-368.

2. Hughes, L., Biological consequences of global warming: is the signal already apparent? Trends in ecology \& evolution, 2000. 15(2): p. 56-61.

3. Root, T.L., et al., Fingerprints of global warming on wild animals and plants. Nature, 2003. 421(6918): p. 57-60.

4. Aresta, M., Carbon dioxide as chemical feedstock2010: John Wiley \& Sons.

5. Blankenship, R.E., et al., Comparing photosynthetic and photovoltaic efficiencies and recognizing the potential for improvement. science, 2011.332(6031): p. 805809.

6. Zhan, Z., et al., Syngas production by coelectrolysis of $\mathrm{CO}_{2} / \mathrm{H}_{2} \mathrm{O}$ : the basis for a renewable energy cycle. Energy \& Fuels, 2009. 23(6): p. 3089-3096.

7. Kondratenko, E.V., et al., Status and perspectives of $\mathrm{CO}_{2}$ conversion into fuels and chemicals by catalytic, photocatalytic and electrocatalytic processes. Energy \& environmental science, 2013. 6(11): p. 3112-3135.

8. Whipple, D.T. and P.J. Kenis, Prospects of $\mathrm{CO}_{2}$ utilization via direct heterogeneous electrochemical reduction. The Journal of Physical Chemistry Letters, 2010. 1(24): p. 3451-3458.

9. $\mathrm{Lu}, \mathrm{Q}$., et al., A selective and efficient electrocatalyst for carbon dioxide reduction. Nature communications, 2014. 5.

10. Zhu, W., et al., Active and Selective Conversion of $\mathrm{CO}_{2}$ to $\mathrm{CO}$ on Ultrathin $\mathrm{Au}$ Nanowires. Journal of the American Chemical Society, 2014. 136(46): p. 1613216135 . 
11. Chen, Y., C.W. Li, and M.W. Kanan, Aqueous $\mathrm{CO}_{2}$ reduction at very low overpotential on oxide-derived Au nanoparticles. Journal of the American Chemical Society, 2012. 134(49): p. 19969-19972.

12. Medina-Ramos, J., J.L. DiMeglio, and J. Rosenthal, Efficient reduction of $\mathrm{CO}_{2}$ to $\mathrm{CO}$ with high current density using in situ or ex situ prepared Bi-based materials. Journal of the American Chemical Society, 2014. 136(23): p. 8361-8367.

13. Rosen, B.A., et al., Ionic liquid-mediated selective conversion of $\mathrm{CO}_{2}$ to $\mathrm{CO}$ at low overpotentials. Science, 2011. 334(6056): p. 643-644.

14. Jones, J.P., G. Prakash, and G.A. Olah, Electrochemical $\mathrm{CO}_{2}$ Reduction: Recent Advances and Current Trends. Israel Journal of Chemistry, 2014. 54(10): p. 1451-1466.

15. Roberts, F.S., K.P. Kuhl, and A. Nilsson, High Selectivity for Ethylene from Carbon Dioxide Reduction over Copper Nanocube Electrocatalysts. Angewandte Chemie, 2015. 127(17): p. 5268-5271.

16. Kas, R, et al., Electrochemical $\mathrm{CO}_{2}$ reduction on $\mathrm{Cu}_{2} \mathrm{O}$-derived copper nanoparticles: controlling the catalytic selectivity of hydrocarbons. Physical Chemistry Chemical Physics, 2014. 16(24): p. 12194-12201.

17. Gattrell, M., N. Gupta, and A. Co, A review of the aqueous electrochemical reduction of $\mathrm{CO} 2$ to hydrocarbons at copper. Journal of Electroanalytical Chemistry, 2006. 594(1): p. 1-19.

18. Kuhl, K.P., et al., New insights into the electrochemical reduction of carbon dioxide on metallic copper surfaces. Energy \& environmental science, 2012. 5(5): p. 7050-7059.

19. Hori, Y., Electrochemical $\mathrm{CO}_{2}$ reduction on metal electrodes, in Modern aspects of electrochemistry2008, Springer. p. 89-189.

20. Li, C.W. and M.W. Kanan, $\mathrm{CO}_{2}$ reduction at low overpotential on $\mathrm{Cu}$ electrodes resulting from the reduction of thick $\mathrm{Cu}_{2} \mathrm{O}$ films. Journal of the American Chemical Society, 2012. 134(17): p. 7231-7234.

21. Kuhl, K.P., et al., Electrocatalytic conversion of carbon dioxide to methane and methanol on transition metal surfaces. Journal of the American Chemical Society, 2014. 136(40): p. 14107-14113.

22. Schouten, K., et al., A new mechanism for the selectivity to C1 and C2 species in the electrochemical reduction of carbon dioxide on copper electrodes. Chemical Science, 2011. 2(10): p. 1902-1909.

23. Othman, M.H.D., et al., High-Performance, Anode-Supported, Microtubular SOFC Prepared from Single-Step-Fabricated, Dual-Layer Hollow Fibers. Advanced materials, 2011. 23(21): p. 2480-2483.

24. Droushiotis, N., et al., Micro-tubular solid oxide fuel cells fabricated from hollow fibres. Journal of Applied Electrochemistry, 2011. 41(9): p. 1005-1012. 
25. Han, D., et al., Optimizing oxygen transport through LaO. 6SrO. 4CoO. $2 \mathrm{Fe} 0.8 \mathrm{O} 3-$ $\delta$ hollow fiber by microstructure modification and $\mathrm{Ag} / \mathrm{Pt}$ catalyst deposition. Energy \& Fuels, 2012. 26(8): p. 4728-4734.

26. Zuo, K., et al., Carbon filtration cathode in microbial fuel cell to enhance wastewater treatment. Bioresource technology, 2015. 185: p. 426-430.

27. Katuri, K.P., et al., A novel anaerobic electrochemical membrane bioreactor (AnEMBR) with conductive hollow-fiber membrane for treatment of low-organic strength solutions. Environmental science \& technology, 2014. 48(21): p. 1283312841.

28. Meng, B., et al., Porous and dense Ni hollow fibre membranes. Journal of Alloys and Compounds, 2009. 470(1): p. 461-464.

29. Luiten-Olieman, M.W., et al., Porous stainless steel hollow fibers with shrinkagecontrolled small radial dimensions. Scripta Materialia, 2011. 65(1): p. 25-28.

30. Tang, W., et al., The importance of surface morphology in controlling the selectivity of polycrystalline copper for $\mathrm{CO}_{2}$ electroreduction. Physical Chemistry Chemical Physics, 2012. 14(1): p. 76-81.

31. Hori, Y., A. Murata, and R. Takahashi, Formation of hydrocarbons in the electrochemical reduction of carbon dioxide at a copper electrode in aqueous solution. Journal of the Chemical Society, Faraday Transactions 1: Physical Chemistry in Condensed Phases, 1989. 85(8): p. 2309-2326.

32. Zhang, Y.-J., et al., Competition between $\mathrm{CO}_{2}$ Reduction and $\mathrm{H} 2$ Evolution on Transition-Metal Electrocatalysts. ACS Catalysis, 2014. 4(10): p. 3742-3748.

33. Schouten, K.J.P., et al., Two pathways for the formation of ethylene in CO reduction on single-crystal copper electrodes. Journal of the American Chemical Society, 2012. 134(24): p. 9864-9867.

34. Vassiliev, Y.B., et al., Electroreduction of carbon dioxide: Part I. The mechanism and kinetics of electroreduction of $\mathrm{CO}_{2}$ in aqueous solutions on metals with high and moderate hydrogen overvoltages. Journal of Electroanalytical Chemistry and Interfacial Electrochemistry, 1985. 189(2): p. 271-294.

35. Gressin, J., et al., Electrochemical reduction of carbon-dioxide in low proton media. NOUVEAU JOURNAL DE CHIMIE-NEW JOURNAL OF CHEMISTRY, 1979. 3(8-9): p. 545-554.

36. Todoroki, M., et al., Electrochemical reduction of high pressure $\mathrm{CO}_{2}$ at $\mathrm{Pb}, \mathrm{Hg}$ and In electrodes in an aqueous KHCO 3 solution. Journal of Electroanalytical Chemistry, 1995. 394(1): p. 199-203.

37. Kas, R, et al., Manipulating the hydrocarbon selectivity of copper nanoparticles in $\mathrm{CO}_{2}$ electroreduction by process conditions. ChemElectroChem, 2015. 2(3): $\mathrm{p}$. 354-358. 
38. Hori, Y., et al., "Deactivation of copper electrode" in electrochemical reduction of $\mathrm{CO}_{2}$. Electrochimica acta, 2005. 50(27): p. 5354-5369.

39. Yano, $\mathrm{H}$., et al., Selective electrochemical reduction of $\mathrm{CO}_{2}$ to ethylene at a threephase interface on copper (I) halide-confined $\mathrm{Cu}$-mesh electrodes in acidic solutions of potassium halides. Journal of Electroanalytical Chemistry, 2004. 565(2): p. 287-293.

40. Cook, R.L., R.C. MacDuff, and A.F. Sammells, High rate gas phase $\mathrm{CO}_{2}$ reduction to ethylene and methane using gas diffusion electrodes. Journal of the Electrochemical Society, 1990. 137(2): p. 607-608.

41. Suddhasatwa, B., Recent trends in fuel cell science and technology, 2007, New York, USA, Springer press.

42. Lu, Q., J. Rosen, and F. Jiao, Nanostructured Metallic Electrocatalysts for Carbon Dioxide Reduction. ChemCatChem, 2015. 7(1): p. 38-47.

43. Furuya, N., T. Yamazaki, and M. Shibata, High performance Ru叉 Pd catalysts for $\mathrm{CO}_{2}$ reduction at gas-diffusion electrodes. Journal of Electroanalytical Chemistry, 1997. 431(1): p. 39-41.

44. Baker, R.W., Membrane technology, 2000: Wiley Online Library.

45. Luiten-Olieman, M.W., et al., Towards a generic method for inorganic porous hollow fibers preparation with shrinkage-controlled small radial dimensions, applied to $\mathrm{Al} 2 \mathrm{O} 3, \mathrm{Ni}$, SiC, stainless steel, and YSZ. Journal of membrane science, 2012. 407: p. 155-163.

46. David, O., Y. Gendel, and M. Wessling, Tubular macro-porous titanium membranes. Journal of membrane science, 2014. 461: p. 139-145.

47. Luiten-Olieman, M.W., et al., Porous stainless steel hollow fiber membranes via dry-wet spinning. Journal of membrane science, 2011. 370(1): p. 124-130. 



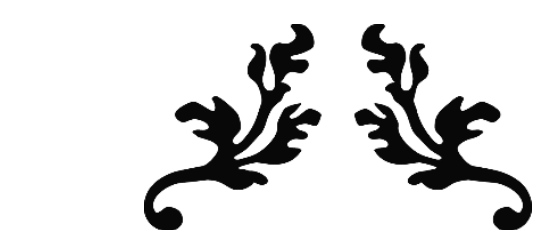

Chapter 7

Summary and Outlook<smiles></smiles> 


\begin{abstract}
The first section of this chapter summarizes the main results presented and discussed in this thesis. The selectivity of electrochemical carbon dioxide reduction is dramatically influenced by the catalyst loading, roughness, surface area and applied process conditions. High surface area electrodes produce mostly $\mathrm{C}_{2}$ hydrocarbons in contrast to smooth polycrystalline electrodes. Ethylene is formed as a result of a high local $\mathrm{pH}$ and pressure, whereas ethane is formed by further hydrogenation of ethylene. Rough surfaces not only result in selective hydrocarbon formation, but also in formation of carbon monoxide. By improving the mass transfer either by elevated pressure or use of gas diffusion electrodes, a high selectivity towards carbon monoxide $(\approx 75 \%)$ can be obtained at low overpotentials $(200-400 \mathrm{mV})$. In the second section of this chapter, theoretical and practical implications of these results to electrochemical carbon dioxide reduction technology are discussed and a perspective is given to further improve the efficiency and rate of the electrochemical conversion of carbon dioxide.
\end{abstract}




\subsection{Summary}

In this thesis the formation of hydrocarbons and/or $\mathrm{CO}$ by $\mathrm{CO}_{2}$ electroreduction was investigated and discussed. The primary aim was to decrease the required overpotential to form hydrocarbons and $\mathrm{CO}$, to achieve an efficient electrochemical process using structured copper electrodes. In addition, understanding of formation of ethylene and/or ethane on structured electrodes was targeted, to obtain design criteria for improvement of the energy efficiency and selectivity of the process.

Firstly, particular attention was given to the fact that rising $\mathrm{CO}_{2}$ levels might irreversibly change the global, and correspondingly local climates. Negative emissions might be required to avoid the catastrophic effects of global warming. By using renewable electricity, pathways to integrate electrochemical $\mathrm{CO}_{2}$ reduction to the chain of the chemical industry were discussed in the first introductory Chapter.

Chapter 2 describes the experimental setup that was constructed in the PhotoCatalytic Synthesis group to study electrochemical $\mathrm{CO}_{2}$ reduction. We built a high pressure electrochemical reactor which is coupled to a GC for continuous analysis of the products. In Figure 1, a typical time vs efficiency graph for ethylene is given. The behavior of the reactor shows typical behavior of a continuously stirred-tank reactor, in which ethylene production requires some time to reach steady state (exit) concentration. The continuous measurement of the products provides a perfect way to monitor the stability of the electrode. Any deactivation or change in the activity of the

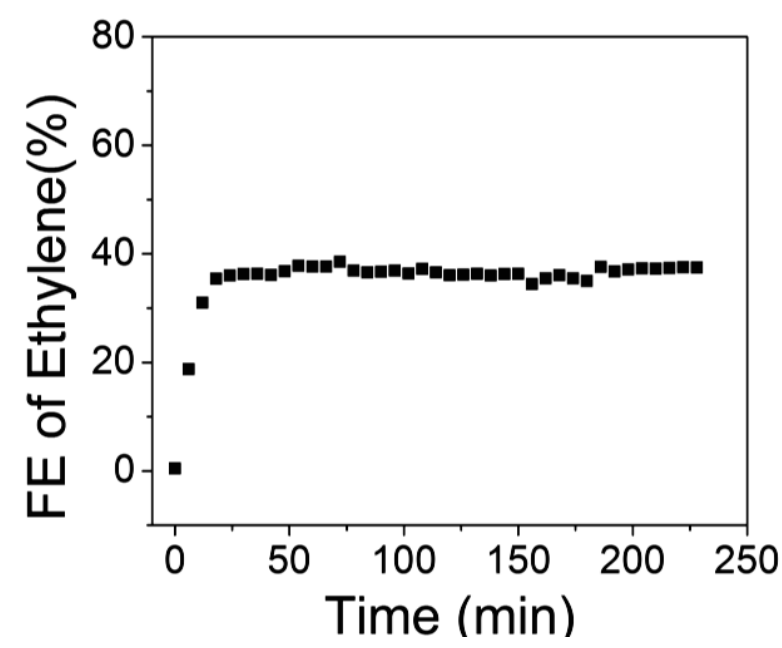

Figure 1: Stable production of ethylene on rough copper electrodes 
electrode are reflected very well in concentration vs time graphs at a constant flow rate of the reactant $\mathrm{CO}_{2}$.

In Chapter 3, we focused on the effect of preparation and loading of the catalyst on the selectivity towards hydrocarbons. The thickness of the initial oxide film, which decomposes to copper nanoparticles at cathodic potentials, determines the catalyst loading and corresponding surface area. We discovered that the roughness of the electrode dramatically effects the selectivity of the electroreduction process (Figure 2 ). As the roughness of the electrodes was increased mildly, methane formation was suppressed. Further increase in roughness lead to formation of ethane which was not reported on smooth copper surfaces previously, even when sensitive methodologies were used. Not only selectivity but the activity of the copper electrodes was changed upon structuring. Online electrochemical mass spectrometry (OLEMS) studies showed that the onset potentials for ethylene were around $-0.5 \mathrm{~V}$ vs RHE whereas ethylene formation started around $-0.7 \mathrm{~V}$ vs RHE on smooth copper electrodes. OLEMS studies also revealed that the initial oxide film decomposes at the very early stage of the reaction and the reaction proceeds on in situ formed copper nanoparticles. This study clarified the reasons behind the different selectivity reported in the literature for copper electrodes prepared by different methods.

In chapter 4, we investigated the origin behind selective formation of ethylene and suppression of methane on mildly roughened electrodes. We studied the effect of

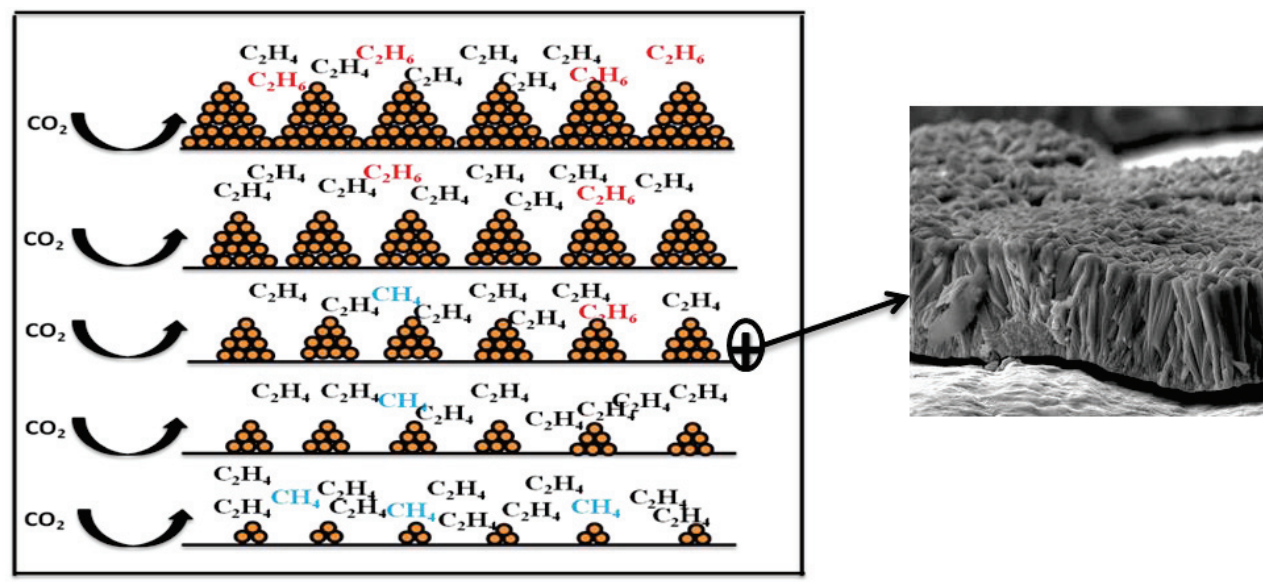

Figure 2: Change in the selectivity with the increasing roughness and surface coverage of copper nanoparticles. The scanning electron microscope image shows cross-sectional image of the $\mathrm{Cu}_{2} \mathrm{O}$ films prepared by electrodeposition. 
buffer capacity and pressure on the selectivity towards methane and ethylene (Figure 3 ). We discovered that rough copper surfaces are also able to produce remarkable amounts of methane if a sufficient amount of protons is supplied by changing the buffer capacity of the solution. Higher pressures can also induce ethylene formation, which is attributed to a higher rate of $\mathrm{CO}$ coupling as a result of an increased rate of $\mathrm{CO}$ production. Moreover, we repeatedly observed deactivation of the electrodes when appreciable amounts of methane were produced, whereas ethylene formation can be sustained for hours. Therefore, we proposed that poisonous intermediates are most likely associated with a pathway producing methane via $\mathrm{COH}$ or $\mathrm{CHO}$ intermediates. Additionally, we discovered that rough copper surfaces can produce $\mathrm{CO}$ at low potentials (-0.4 vs RHE) and moderate pressures ( $9 \mathrm{~atm})$ with reasonable faradaic efficiencies up to $72 \%$. This is the highest selectivity ever reported towards $\mathrm{CO}$ on copper surfaces from $\mathrm{CO}_{2}$ electroreduction. This study also clarified the origin behind the selective ethylene formation on rough copper electrodes. Ethylene is formed as a result of a high local current density on rough electrodes, and a relatively low proton concentration near the electrode surface.

In Chapter 5, we studied how ethane is formed on rough copper electrodes. Ethane is a recently reported product of $\mathrm{CO}_{2}$ electroreduction, which was observed on roughened copper surfaces prepared with different methods such as electrodeposition, hydrogenation etc. We demonstrated for the first time that ethane is formed by

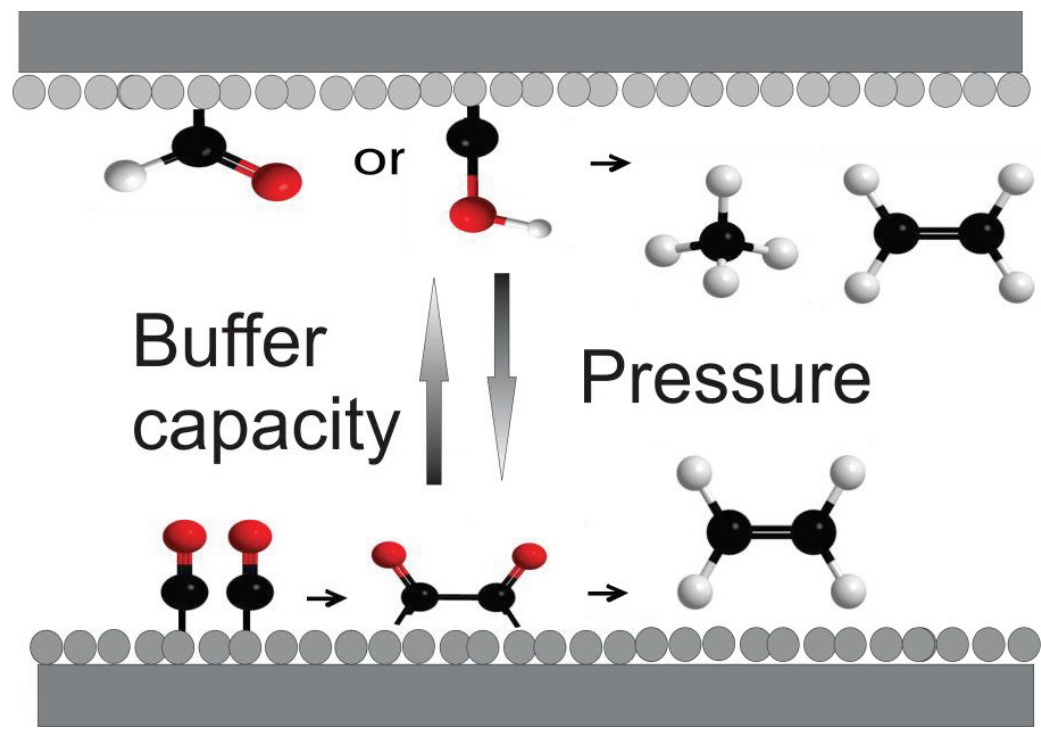

Figure 3: Key intermediates for the formation of ethylene and methane. The formation of these intermediates can he controlled bv the annlied nrocess conditions. 

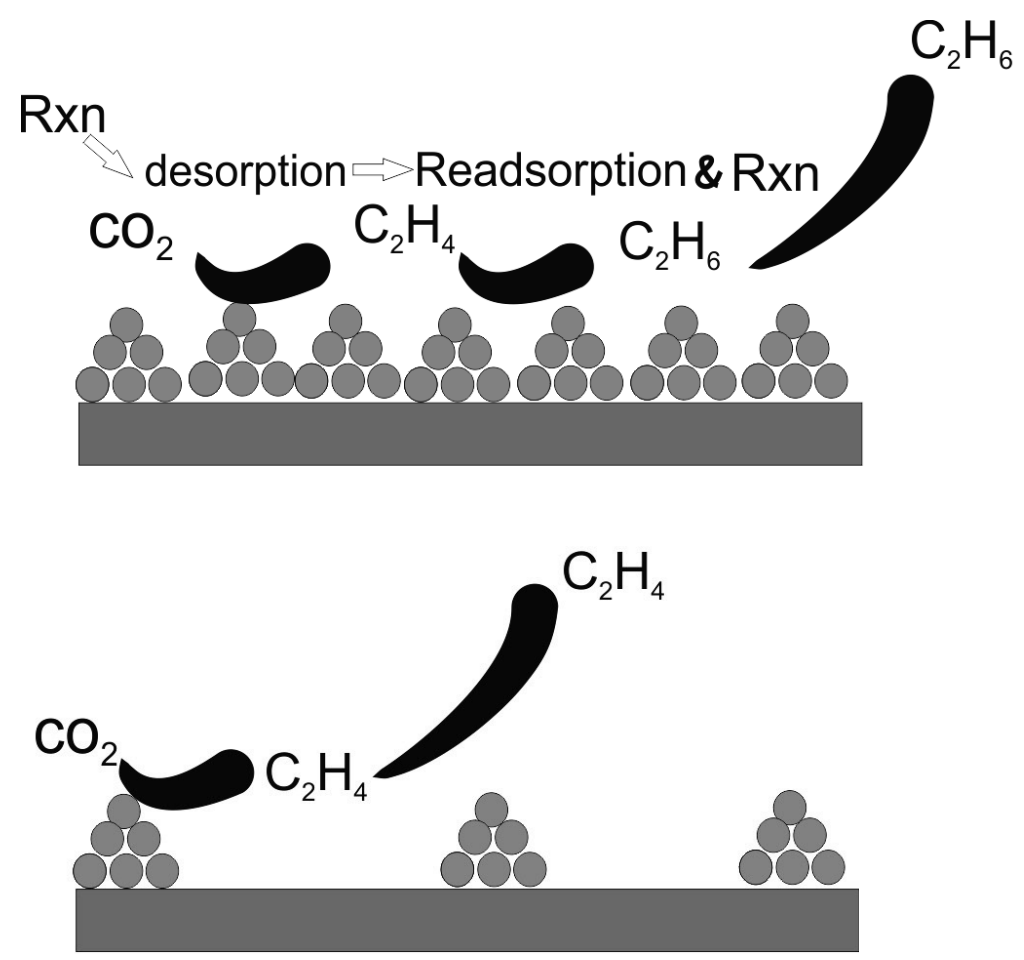

Figure 4: Schematic representation of desorption-adsorption and the further reaction mechanism

electrochemical hydrogenation of ethylene. We discovered that ethylene can be reduced to ethane electrochemically both on smooth and rough copper surfaces. However, ethane formation is observed only on sufficiently rough copper electrodes when $\mathrm{CO}_{2}$ is used as precursor. Addition of iodide ions into the solution was used to demonstrate that ethylene is reduced further to ethane by re-adsorption on the surface of the electrodes, when a high catalyst loading is used (Figure 4). This is attributed to an increased number density/surface coverage of the nanoparticles, inhibition of sorption of ethylene by iodide, and the defect rich structure of the electrodes.

In Chapter 6, we designed copper electrodes by using the following information that we obtained during our research
i) Rough copper electrodes can reduce $\mathrm{CO}_{2}$ to $\mathrm{CO}$ at low overpotentials

ii) High pressures can boost $\mathrm{CO}_{2}$ to $\mathrm{CO}$ efficiency 


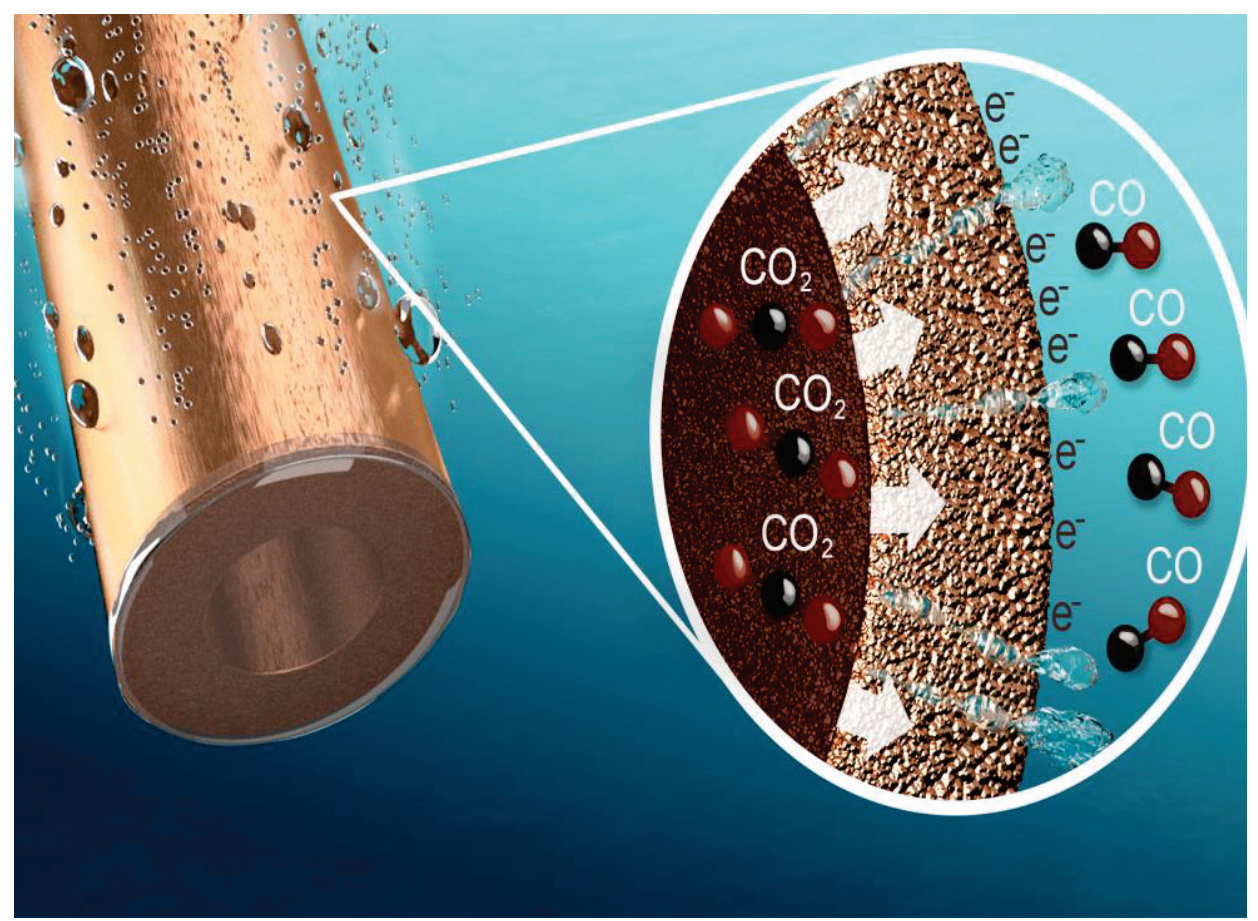

Figure 5: Schematic representation of a Copper hollow fiber used as a cathode and gas diffuser.

We prepared porous, defect rich and rough copper hollow fibers and used them as both cathode and a gas diffuser (Figure 5). We reached $\mathrm{FE}$ of $85 \%$ towards $\mathrm{CO}_{2}$ reduction products at very low overpotentials $(200 \mathrm{mV}-400 \mathrm{mV})$ with partial current densities ranging from 3-17 $\mathrm{mAcm}^{-2}$. We obtained unprecedentedly high $\mathrm{CO}$ formation rates on copper surfaces which are higher or comparable to $\mathrm{CO}$ evolving noble metal catalysts, such as silver and gold. The onset potential for $\mathrm{CO}$ formation is just above the equilibrium potential $(\dot{\eta} \approx 50 \mathrm{mV})$ which implies not only improved mass transfer, but also an efficient electrocatalyst. The hollow fiber catalyst showed a quite stable performance during 24 hours of continuous electrolysis.

\subsection{Outlook}

Reduction of $\mathrm{CO}_{2}$ emissions while sustaining economic growth, remains one of the top challenges of humanity. As the energy resources evolve from fossil fuels to renewables, electrosynthesis will be very essential to produce cheap and high quality products. The chlorine industry has been using this technology for decades but the 
opportunities for other applications have not yet been significantly exploited. Electrochemical reduction of $\mathrm{CO}_{2}$ to fuels or other chemicals, driven by renewable electricity, is a promising technology to close the anthropogenic carbon cycle, in particular when performed in water, since water is a cheap, abundant and industrially approved solvent. Yet, aqueous conversion of $\mathrm{CO}_{2}$ has not been achieved so far with sufficient activity. This requires an earth abundant efficient and stable electrocatalyst which can convert $\mathrm{CO}_{2}$ to fuels or fuel type molecules. Copper is an attractive nontoxic metal with high abundance and relatively low and stable prize. The major drawbacks of copper electrodes are stability and high overpotentials required for the formation of energy dense products, i.e. methane and ethylene. Understanding how these products are formed is very essential to improve the efficiency of the electrochemical process.

For fundamental understanding of ethylene formation on rough copper surfaces, we contributed significantly to the literature. In addition, an improvement of $200 \mathrm{mV}$ is achieved for the onset potential of ethylene formation on rough surfaces. However still high potentials are required to produce ethylene electrochemically which decreases the overall efficiency of the process. High overpotentials will be reflected as a consumption of electricity in any industrial electrochemical process and the cost of the process will very much rely on to the electricity prize. Ethylene can be formed at low potentials by starting from $\mathrm{CO}$, as discovered by the Catalysis and Surface Chemistry group in Leiden. Using this information, Matthew Kanan and his coworkers at Stanford University produced ethanol (57\%) in highly alkaline solutions at moderate potentials. Even though such a process is very important to electrify the chemical industry, an initial conversion of $\mathrm{CO}_{2}$ to $\mathrm{CO}$ is required. Converting $\mathrm{CO}_{2}$ to ethylene or ethanol via a two-step electroreduction process has not been evaluated economically to the best of our knowledge. Yet such a process will require two distinctive electrochemical and separation processes which most likely will become very energy intensive and expensive. Direct electroreduction of $\mathrm{CO}_{2}$ to energy dense products is still a significant challenge for the electrocatalysis society.

One of the most original and intriguing results we obtained is the deactivation of copper when methane is produced on the electrode. It was very important to discover that a $\mathrm{CO}$ dimerization pathway does not lead to poisonous species on the electrode surface, which are most likely associated with a $C_{1}$ pathway. This is also important, since CO dimerization leads to ethylene and is energetically much more promising when compared to the formation of methane. However, it is still required to 
clarify the identity of the poisonous intermediates by using in situ or ex situ spectroscopic analysis.

Understanding formation of ethane is very essential, since any process intended to produce ethylene might produce ethane as byproduct. In industrial electrochemical processes or fuel cells, well dispersed high surface area catalysts on an inert support are commonly used. Therefore, it is highly likely that very high surface area electrocatalysts are beneficial for effective conversion of $\mathrm{CO}_{2}$ and/or $\mathrm{CO}$ to ethylene. We showed the surface coverage and number density of the catalyst dramatically influences the selectivity of the process. Therefore, the dispersion of the catalyst particles on the support material will be very critical to achieve high selectivity towards ethylene. Additives or co-catalysts can be used to switch the selectivity towards ethylene or ethane, depending on the application and the desired chemical product.

The most important practical result that we achieved was the efficient and high rate production of $\mathrm{CO}$ at low potentials by using copper hollow fibers. Silver and gold are the top two metals producing $\mathrm{CO}$ with high $\mathrm{FE}$ and they are studied extensively in the literature. Gold is way too expensive, comparable in price to platinum. Researchers are worldwide challenged to find a replacement of platinum to produce cheap fuel cells. Similarly, silver is 10 times more expensive and 100 times less abundant than copper. In addition, researchers also try to find a replacement for silver, which was the metal used in the discovery of ionic liquid mediated $\mathrm{CO}_{2}$ to $\mathrm{CO}$ reduction. Therefore, achieving high $\mathrm{FE}$ and current density at low potentials by using hollow fibers is very important to show copper can be a potential candidate for $\mathrm{CO}$ production as well. More importantly, the hollow fibers allow easy process control of the internal and external microstructure which can be further optimized to get higher production rates. The hollow fibers have been successfully applied in solid oxide fuel cells, enabling a high power density, and compact and low cost cells. Integrating this technology to liquid phase electrochemistry was a first step to design microtubular room temperature electrochemical reactors. However, the structure of the hollow fiber should be systematically studied to optimize the $\mathrm{CO}_{2}$ distribution and utilization of the maximum electrochemically active surface area. Cheaper and higher strength materials can be used as both support and diffusion medium, whereas the catalyst layer structure and material can be controlled by using different methods such as spinning, electrodeposition. Application of the fibers is projected to yield exciting results also in other electrochemical processes. 



\section{Samenvatting}

In dit proefschrift wordt de vorming van koolwaterstoffen en/of $\mathrm{CO}$ door elektroreductie van $\mathrm{CO}_{2}$ onderzocht en besproken. Het primaire doel was om de vereiste overpotentiaal om koolwaterstoffen en $\mathrm{CO}$ te vormen te verlagen, en om een efficiënt elektrochemisch proces te realiseren met gestructureerde, koper elektrodes. Verder werd inzicht in de formatie van etheen en/of ethaan over gestructureerde koper elektrodes nagestreefd, om ontwerpcriteria af te leiden voor de verbetering van de energie-efficiëntie en selectiviteit van het proces.

Ten eerste werd specifiek aandacht besteed aan het feit dat de stijgende $\mathrm{CO}_{2-}$ niveaus onomkeerbaar het wereldklimaat, en daaraan gerelateerd lokale klimaten, kunnen veranderen. Negatieve uitstoot zou nodig zijn om de catastrofale effecten van de opwarming van de aarde te voorkomen. Elektrochemische reductie van $\mathrm{CO}_{2}$ door middel van duurzaam opgewekte elektriciteit, als onderdeel van de synthese keten van de chemische industrie, wordt besproken in het eerste, inleidende hoofdstuk.

Hoofdstuk 2 beschrijft de experimentele opstelling die werd gebouwd in de PhotoCatalytic Synthesis groep om elektrochemische $\mathrm{CO}_{2}$ reductie te bestuderen. We hebben een hogedruk elektrochemische reactor gebouwd, die gekoppeld is aan een GC voor continue analyse van de producten. In Figuur 1 is een typische tijd vs efficiëntie grafiek voor etheen weergegeven. Het gedrag van de reactor toont gedrag van een continu geroerde tank-reactor, waarin etheenproductie enige tijd vergt om

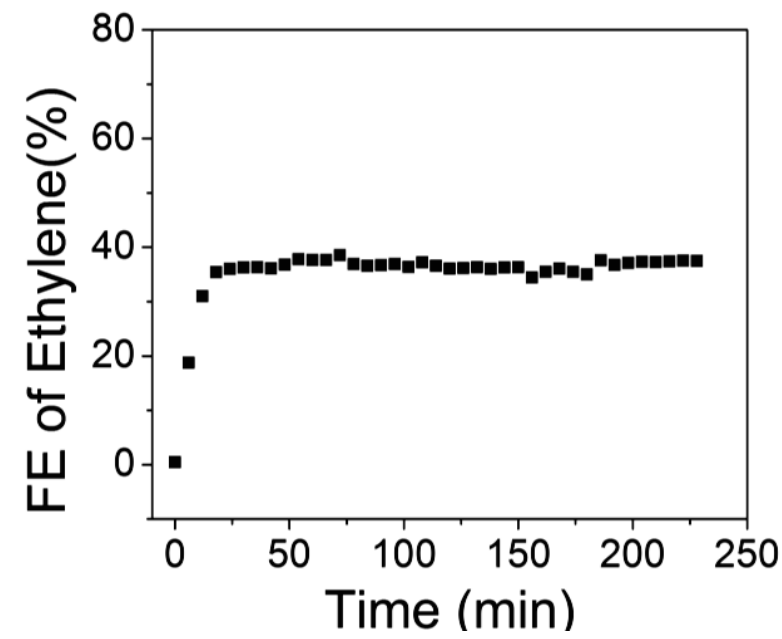

Figuur 1: Stabiele productie van etheen op ruwe, koperen elektrodes 
een constante uitgangsconcentratie te bereiken. De continue meting van de producten biedt een perfecte manier om de stabiliteit van de elektrode te volgen. Iedere deactivering of wijziging van de activiteit van de elektrode komt zeer goed tot uiting in de concentratie vs tijd grafieken bij een constante invoersnelheid van de reactant $\mathrm{CO}_{2}$.

In hoofdstuk 3 hebben we ons gericht op het effect van de bereidingsmethode en de belading van de precursor van de actieve koperdeeltjes $\left(\mathrm{Cu}_{2} \mathrm{O}\right)$ op de selectiviteit naar koolwaterstoffen. De dikte van de oxidelaag, die naar koperen nanodeeltjes ontleedt door kathodische reductie, bepaalt de ruwheid van de elektrode. Deze heeft een dramatische invloed op de selectiviteit van het elektroreductie proces van $\mathrm{CO}_{2}$ (Figuur 2). Wanneer de ruwheid van de elektrodes enigszins wordt verhoogd, wordt methaanvorming onderdrukt. Verdere toename van de ruwheid leidt tot de vorming van ethaan. Dit was niet eerder gerapporteerd voor gladde koper oppervlaktes, zelfs niet wanneer gevoelige analyse methodieken werden gebruikt. Niet alleen selectiviteit, maar ook de activiteit van de koperen elektrodes verandert door structurering. Online elektrochemische massaspectrometrie (OLEMS) toonde aan dat de 'onset' potentiaal voor etheen ongeveer $-0,5 \mathrm{~V}$ vs RHE bedraagt, terwijl etheen formatie op gladde, koperen elektrodes bij $-0,7 \mathrm{~V}$ vs RHE begint. OLEMS studies toonden tevens aan dat de aanvankelijke oxidelaag ontbindt gedurende de initiële fase van de reactie en dat de reactie verloopt op in situ gevormde koperen nanodeeltjes. Deze studie verduidelijkt de oorzaken van de verschillende selectiviteiten gerapporteerd in de literatuur voor koper elektrodes

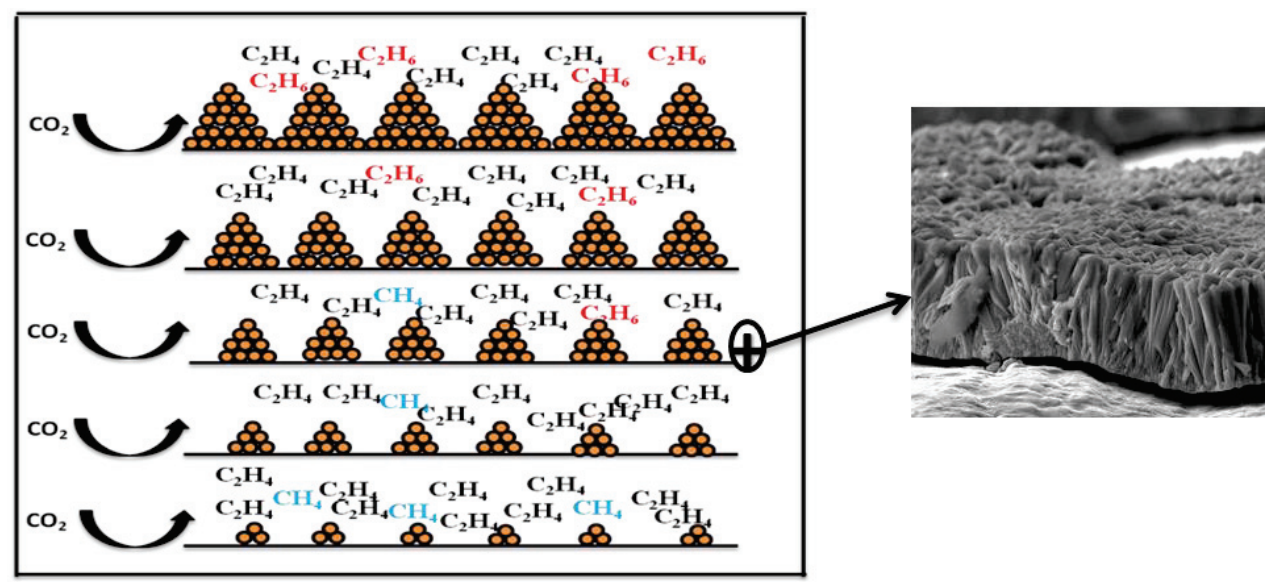

Figuur 2: Verandering van de selectiviteit met toenemende ruwheid en oppervlaktebedekking van koperen nanodeeltjes. Het rasterelektronenmicroscoop-plaatje toont een dwarsdoorsnede beeld van de $\mathrm{Cu} O \mathrm{O}$ films bereid met elektrodenositie. 
bereid vanuit oxidische koperdeeltjes.

In hoofdstuk 4 hebben we de oorzaak achter de selectieve vorming van etheen, en de onderdrukking van methaan op licht ruwe koper elektrodes onderzocht. Met name het effect van de buffercapaciteit, en de $\mathrm{CO}_{2}$ druk op de selectiviteit naar methaan en etheen (Figuur 3) wordt beschreven. We ontdekten dat ruwe koper oppervlaktes ook opmerkelijke hoeveelheden methaan kunnen produceren, wanneer voldoende protonen aanwezig zijn in de reactieve grenslaag tussen electrode en electrolyt, welke wordt beïnvloed door de buffercapaciteit van de oplossing. Hoge drukken kunnen ook etheen formatie induceren, wat wordt toegeschreven aan een hogere $\mathrm{CO}$ koppelingssnelheid als gevolg van een hoge locale $\mathrm{CO}$ concentratie. Bovendien hebben we herhaaldelijk deactivatie van de elektrodes waargenomen wanneer aanzienlijke hoeveelheden methaan geproduceerd werden, terwijl etheen vorming urenlang volgehouden kan worden. Daarom stellen we voor dat inhibiterende producten waarschijnlijk ontstaan in een route waar methaan via $\mathrm{COH}$ of $\mathrm{CHO}$ gevormd wordt. Daarnaast ontdekten we dat ruwe, koper oppervlaktes $\mathrm{CO}$ kunnen produceren bij lage potentialen $(-0,4 \mathrm{~V}$ vs RHE) en een gematigde druk (9 atm), met redelijke Faraday-efficiënties tot $72 \%$. Dit is de hoogste selectiviteit ooit gerapporteerd in $\mathrm{CO}_{2}$ elektroreductie naar $\mathrm{CO}$ op koper oppervlaktes. Deze studie verduidelijkt ook de oorsprong achter de selectieve etheen formatie op ruwe, koperen elektrodes. Etheen wordt gevormd als gevolg van een hoge lokale stroomdichtheid op ruwe elektrodes en een relatief lage proton concentratie nabij het elektrodeoppervlak.

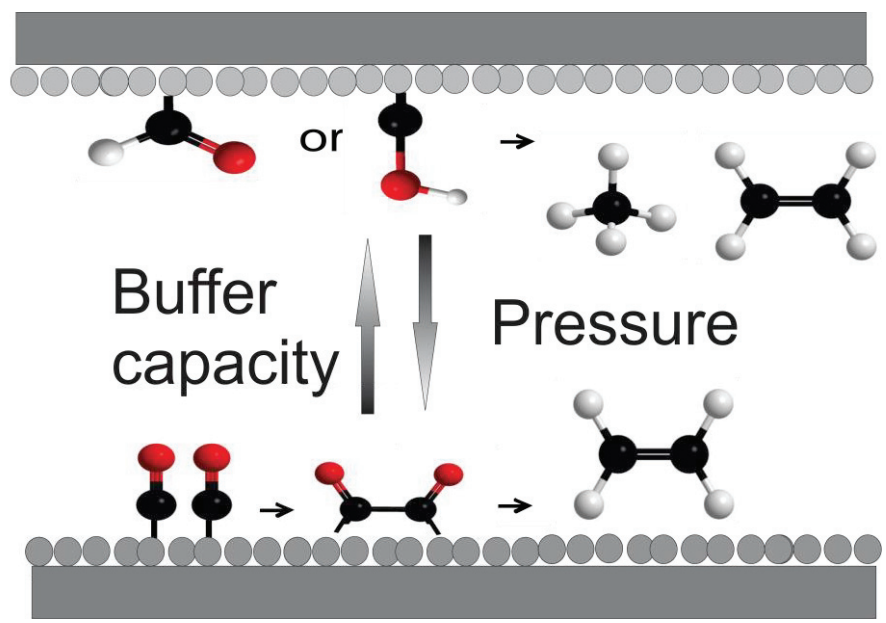

Figuur 3: Belangrijke tussenstappen in de vorming van etheen en methaan. De vorming van de tussenproducten kan gecontroleerd worden door de toegepaste procescondities aan te passen. 
In hoofdstuk 5 hebben we onderzocht hoe ethaan wordt gevormd op ruwe, koperen elektrodes. Ethaan is een recent gerapporteerd product in $\mathrm{CO}_{2}$ elektroreductie, dat werd waargenomen op ruwe, koperen oppervlaktes bereid door middel van verschillende methodes, zoals elektrodepositie, hydrogenering etc. We toonden voor de eerste keer aan dat ethaan wordt gevormd door elektrochemische hydrogenering van etheen. We ontdekten dat etheen elektrochemisch gereduceerd kan worden tot ethaan op zowel gladde als ruwe, koperen oppervlaktes. Ethaan formatie wordt echter alleen waargenomen op koperen elektrodes die ruw genoeg zijn. Toevoeging van jodide-ionen in de oplossing werd gebruikt om aan te tonen dat etheen inderdaad verder gereduceerd wordt tot ethaan na re-adsorptie aan het ruwe oppervlak van de elektrodes (Figuur 4). Remming van de adsorptie van etheen door jodide, verlaagt de vormingssnelheid van ethaan.

In hoofdstuk 6 hebben we koperen elektrodes ontworpen met behulp van de volgende informatie die hierboven is beschreven en als volgt kan worden samengevat:
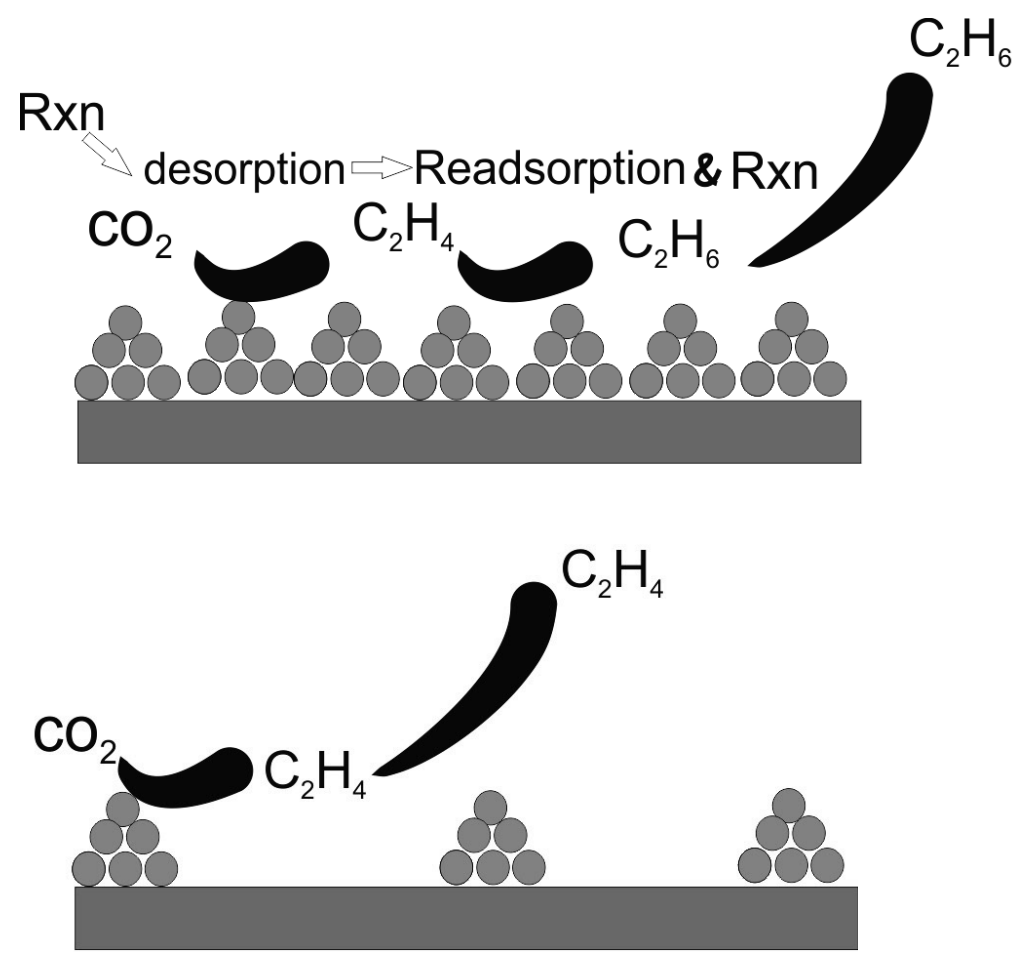

Figuur 4: Schematische weergave van desorptie-adsorptie en het verdere reactiemechanisme 


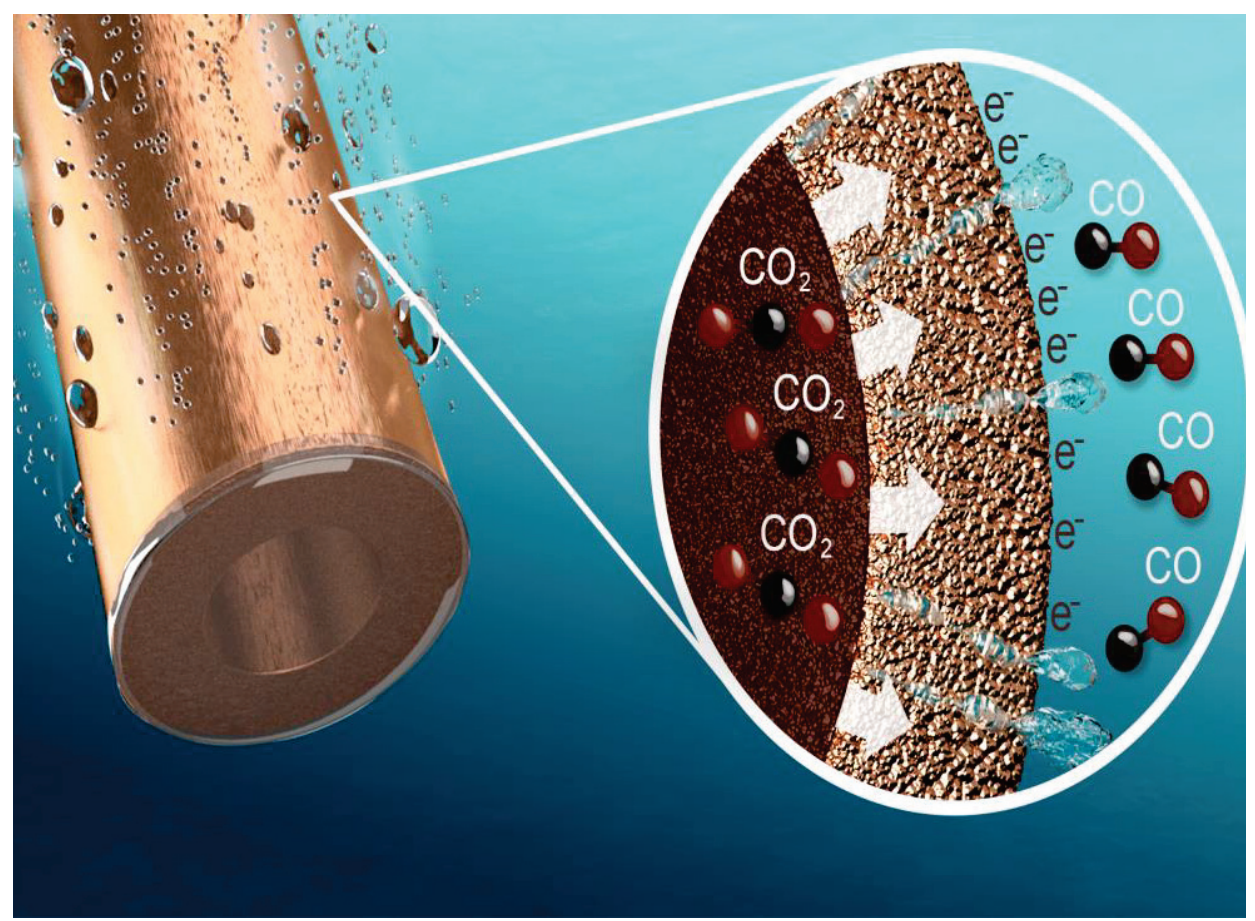

Figuur 5: Schematische weergave van een koperen, holle vezel gebruikt als een kathode en gas diffuser.

i) Ruwe, koperen elektrodes kunnen $\mathrm{CO}_{2}$ naar $\mathrm{CO}$ reduceren bij lage overpotentialen

ii) Hoge drukken kunnen $\mathrm{CO}_{2}$-naar-CO efficiëntie stimuleren

We hebben poreuze, defect-rijke en ruwe, koperen, holle vezels bereid en gebruikt als zowel kathode als gas diffuser (Figuur 5). We bereikten een FE van $85 \%$ naar producten die ontstaan door $\mathrm{CO}_{2}$ reductie bij zeer lage overpotentialen $(200 \mathrm{mV}$ $400 \mathrm{mV}$ ) met stroomdichtheden variërend van 3 tot $17 \mathrm{~mA} \mathrm{~cm}$. We verkregen ongekend hoge $\mathrm{CO}$ vormingssnelheden op koperen oppervlaktes, die hoger of vergelijkbaar zijn met CO-ontwikkelende edelmetaalkatalysatoren, zoals zilver en goud. De 'onset' potentiaal voor $\mathrm{CO}$ formatie ligt net boven de evenwichtspotentiaal $(\eta \approx 50 \mathrm{mV}$ ), wat niet alleen verbeterde massaoverdracht impliceert, maar ook een hoge efficiënte van de elektrokatalysator. De holle vezel katalysator liet een redelijk stabiele productie zien in continue elektrolyse gedurende 24 uur. 



\section{Acknowledgements}

So, the end of the road... I can't imagine myself living at the same place for the rest of my life. So it is good to move I guess. On the other hand, I hate goodbyes. I have to say goodbye to all the nice people that I met in Netherlands and I would like to acknowledge the people that made this work possible.

First of all, I would like to thank my supervisor Guido Mul for giving the opportunity to work in his research labs. I learned a lot of things from your research and management skills. The most important thing is that you were always easygoing and positive regardless of the situation. Thank you very much for your patience, motivation and support. I always think you manage stress very well and this is why you still look you are at your 30s. I would like to thank Jonas Baltrusaitis whom supervised me for a one year. With you, I have experienced very much how to deal with a solid and welldisciplined professor. You were truly an exceptional person which I will always remember.

I would like to express my gratitude to Marc Koper for his distinctive advices and perspectives to our research problems. I will never forget the moment that you picked up a book from your library and open the relevant page upon my question. I have learned many things from you which I should have spent weeks to understand. Thank you very much for your detailed e-mails and for your patience to respond my long e-mails.

I would like to thank Paul Kenis for giving me the honor of being the committee member for my $\mathrm{PhD}$ defense. I am also really grateful for your friendly approach, support and patience to my questions during project writing. I also would like to acknowledge Nieck Benes who is very kind and at the same time critical. Thank you very much for your constructive comments during our collaboration. My sincere thanks also goes to Rob Van Veen and Henny Bouwmeester, for evaluating my thesis and being part of this important moment of my career.

I would like to thank Robert for his continuous support and patience. I always say you are the concrete of the group and we could have no chance to run experiments this efficiently without your help. I also would like to thank to Lidy for her kind approach for our problems and requests.

I would like to thank my paranymphs Kasper Wenderich and Alexander Milbrat. Kasper, I think that I will live at least one year more by the positive energy you spread. I will always miss a person like you to be around. Alexander, you have a brilliant 
personality and I have never heard anything harsh from you for 4 years. You a perfect listener and also a very descriptive and detailed story teller.

I would like to thank also Hasan for his patience and friendship for 4 years. After exposed by a different culture, we together figured out the things that we learned from our culture and family might be fundamentally wrong. I am deeply appreciated, though sometimes get sick of it:- for your opposing questions that makes me think and develop different perspectives. I wish you a successful and more importantly happy academic career. I would like to thank Engin for his support and friendship when I first started my $\mathrm{PhD}$ (fakire ekmek). I learned many things from you which are not only scientific but also social. I think you are the person I would like to have with me if I ever end up in a desolated island. You are a perfect story teller and a nice friend to spend time together. I would like to also thank to Ozlem and Asya Roza for their friendship and hospitality.

I would like to thank Xenia whom I learned fundamental concepts of electrochemistry. Xenia, I admire your skills that balance your academic and personal life. You are a perfect person to hang out and spend time together. Bindikt, I always think you are "the" person to be sent to the "alien" world if we ever make a contact with another planet during our lifetimes. Rezvenah, we were like Bert and Ernie all the time but the discussions were always to improve our knowledge and perspective. Joana, I admire your friendship style which is based on "support your friends, even if you don't support their situation”, which I can barely achieve. Sun-Young, an energetic person, I think I figured out why you are always happy. I hope you always stay like that.

I would like to acknowledge Ruud and Jing whom I really like to spend time in and out of the lab. I really enjoyed from our discussions and I learned many things from you. I also acknowledge collogues with whom I had the opportunity to have valuable scientific discussions; Michel, Kai, Hamdy, Zheng, Damon, Wojciech, Yi, Yan, ChiehChao. I would like to thank Vera for her scientific support and kind approach during the last months of my $\mathrm{PhD}$. You are one of the smartest people I have ever seen. I would like to also thank to the nice people who joined recently to our group, Robert, Yuxi, Alexandre, for their positive energy. I also would like to thank Thije for his hard work and eggs:- Thije, you make me feel the new generation is smarter and cleverer.

I would like to thank Khalid for his patience to my criticisms $;$; and harsh comments. I just tried to make you question the things in our culture that we have taken 
for granted. I would also like to thank for your hard work in the lab and your "extremely" friendly approach. You are one of the people that I will never forget.

I would like to thank my everlasting fellows Enes and Erhan for their support and critical approaches. You are the people whom I could share my good and bad memories without hesitating. You guys made me feel like I am at home. Thank you very much for your contribution to the cover page design as well. I would like to thank Yusuf who is one of the few people that I think: wish this guy was here now. I would like to thank; Murat, for his unique sense of humor, Eren, for his unique perspectives, my favourite couple, Oguzcan and Kardelen, for their companion, Muharrem, the guy nearly all the people like, Alim, gordugum zaman mutlu oldugum insan. I would like to also thank to the nice and cheerful people Yakup, Duygu, Engin, Devrim, Mehmet, Damla, Sedef, Makin, Burcu, Emre, Eda, Aylin, Sinem, Semih, Didem, Sertan, Ozlem, Gokce, Namik, Hayrettin, Nurcan, Bedile.

Son olarak eğitim ve öğretimin önemi anlayan ve bilen aileme bana sundukları bütün destek için teşekkür ederim. Sizin desteğiniz olmadan hayatta başardığım hiçbir şey var olmazdı. Her ne kadar fikirlerimiz farklı da olsa siz bana düşünceli olmayı, empati kurmayı ve insanlara yardım etmeyi öğrettiniz ve koşullar ne olursa olsun yanımda olacağınızdan eminim. 



\section{Publications in University of Twente}

1- Recep Kas, Ruud Kortlever, Alexander Milbrat, Marc Koper, Guido Mul, and Jonas Baltrusaitis. "Electrochemical $\mathrm{CO}_{2}$ reduction on $\mathrm{Cu}_{2} \mathrm{O}$-derived copper nanoparticles: controlling the catalytic selectivity of hydrocarbons." Physical Chemistry Chemical Physics 16, no. 24 (2014): 12194-12201.

2- Recep Kas, Ruud Kortlever, Hasan Y1lmaz, Marc Koper, and Guido Mul. "Manipulating the hydrocarbon selectivity of copper nanoparticles in $\mathrm{CO}_{2}$ electroreduction by process conditions." ChemElectroChem 2, no. 3 (2015): 354-358.

3- Recep Kas, Khalid Khazzal Hummadi, Ruud Kortlever, Patrick de Wit, Alexander Milbrat1, Mieke W. J. Luiten-Olieman, Nieck E. Benes, Marc Koper and Guido Mul. "3-D porous hollow fiber electrodes for efficient and high-rate electrochemical carbon dioxide reduction" Nature communications, Accepted (2015).

4- Kas Recep., Kortlever Ruud., Koper Marc., Mul Guido "On the formation of ethane on copper nanoparticles during $\mathrm{CO}_{2}$ electroreduction". Manuscript in preparation

5- Engin Karabudak, Recep Kas, Wojciech Ogieglo, Damon Rafieian, Stefan Schlautmann, R. G. H. Lammertink, Han JGE Gardeniers, and Guido Mul. "Disposable attenuated total reflection-infrared crystals from silicon wafer: a versatile approach to surface infrared spectroscopy." Analytical chemistry 85, no. 1 (2012): 33-38.

6- Shen Jing, Ruud Kortlever, Recep Kas, Yuvraj Y. Birdja, Oscar Diaz-Morales, Youngkook Kwon, Isis Ledezma-Yanez, Klaas Jan P. Schouten, Guido Mul, and Marc TM Koper. "Electrocatalytic reduction of carbon dioxide to carbon monoxide and methane at an immobilized cobalt protoporphyrin." Nature communications 6 (2015).

7- Alexander Milbrat, Rick Elbersen, Recep Kas, Roald M. Tiggelaar, Han Gardeniers, Guido $\mathrm{Mul}^{*}$, and Jurriaan Huskens" Spatio-selective Electrochemical and Photoelectrochemical Functionalization of Silicon Microwires with Axial p/n Junctions” Advanced Materials Accepted, (2015).

8- Kortlever Ruud; Peters Ines; Balemans Collin; Kas Recep; Kwon Youngkook; Mul Guido; Koper Marc. "Palladium-gold catalyst for the electrochemical reduction of $\mathrm{CO}_{2}$ to $\mathrm{C} 1-\mathrm{C} 5$ hydrocarbons" Submitted to JACS 



\section{Curriculum Vitae}

Recep Kas was born on 1986 in Bursa, Turkey. In 2009, he graduated with a degree of Bachelor from Koc University in Turkey, majoring in Chemistry. He worked in polymer and nanomaterials research lab on the synthesis of magnetic and luminescent hybrid nanoparticles for 3 summers during bachelor education. In 2011, he graduated with a degree of Master from Koc University, majoring in Material Science and Engineering. The title of his master thesis is "Application of ultrasound to the morphology control of crystals and deposition of nanoparticles". In 2012, he started his PhD study in the group of photocatalytic synthesis at the University of Twente in Netherlands. During his $\mathrm{PhD}$, he has been working on electrochemical $\mathrm{CO}_{2}$ reduction. 

Our planet is a lonely speck in the great enveloping cosmic dark. Our posturings, our imagined self-importance, the delusion that we have some privileged position in the Universe, are challenged by this point of pale light. In our obscurity, in all this vastness, there is no hint that help will come from elsewhere to save us from ourselves.

Carl Sagan 